\title{
Assessment of Development Impacts on Coastal Zone: Integrated Approach, Northampton County, Eastern Shore, Virginia
}

\author{
Sarunas Zableckis \\ College of William and Mary - Virginia Institute of Marine Science
}

Follow this and additional works at: https://scholarworks.wm.edu/etd

Part of the Ecology and Evolutionary Biology Commons, Geography Commons, and the Natural Resources Management and Policy Commons

\section{Recommended Citation}

Zableckis, Sarunas, "Assessment of Development Impacts on Coastal Zone: Integrated Approach, Northampton County, Eastern Shore, Virginia" (2001). Dissertations, Theses, and Masters Projects. Paper 1539617778.

https://dx.doi.org/doi:10.25773/v5-t1mn-h744

This Thesis is brought to you for free and open access by the Theses, Dissertations, \& Master Projects at W\&M ScholarWorks. It has been accepted for inclusion in Dissertations, Theses, and Masters Projects by an authorized administrator of W\&M ScholarWorks. For more information, please contact scholarworks@wm.edu. 


\title{
ASSESSMENT OF DEVELOPMENT IMPACTS ON COASTAL ZONE: INTEGRATED APPROACH NORTHAMPTON COUNTY, EASTERN SHORE, VIRGINIA
}

\author{
A Thesis \\ Presented to \\ The Faculty of the School of Marine Science \\ The College of William and Mary in Virginia
}

In Partial Fulfillment

Of the Requirements for the Degree of

Master of Science

\author{
by \\ Sarunas Zableckis \\ 2001
}


APPROVAL SHEET

This thesis is submitted in partial fulfillment of the requirements for the degree of

Master of Science

Barman Rableckes" Sarunas Zableckis

Approved, June 2001
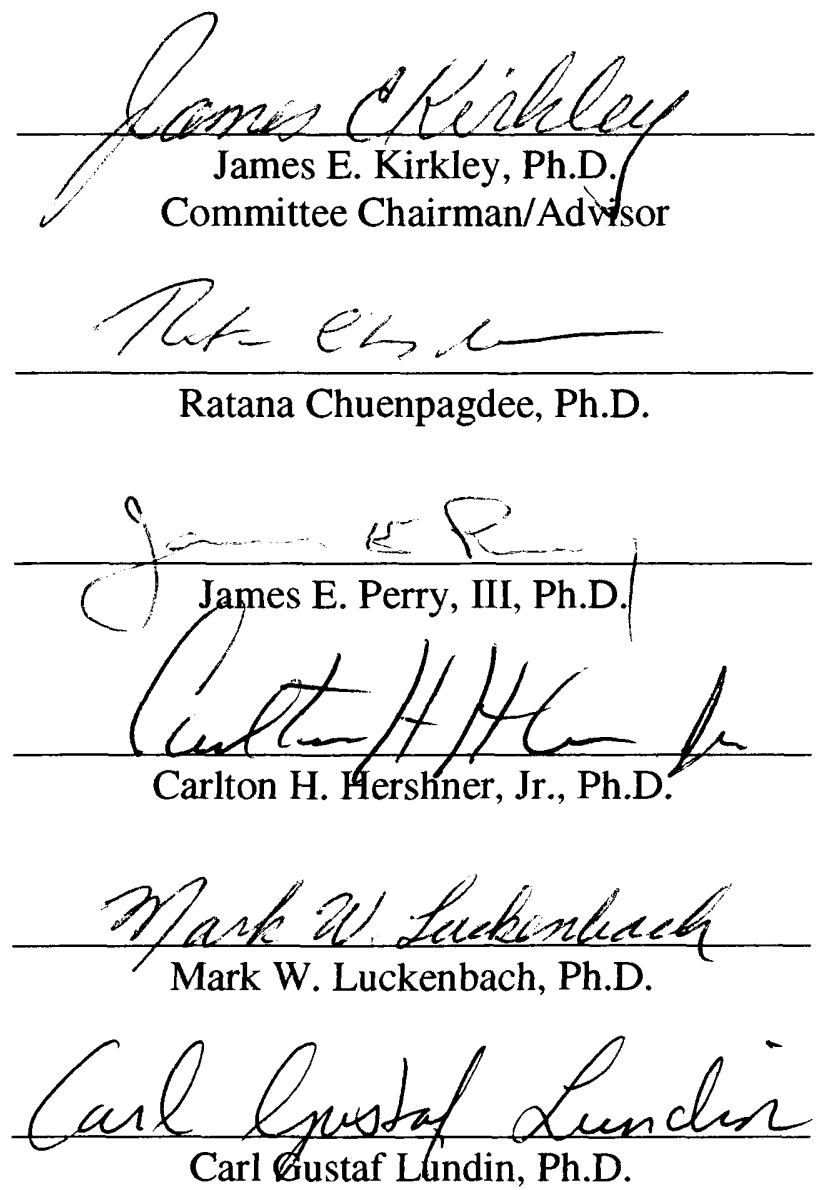

The World Bank

ii 


\section{TABLE OF CONTENTS}

Page

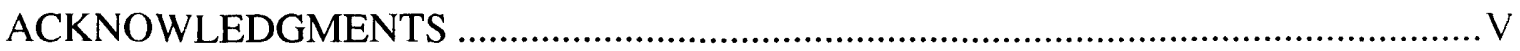

LIST OF TABLES

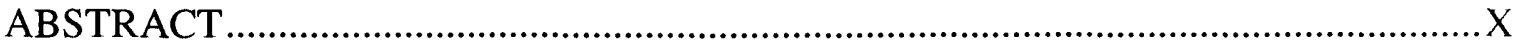

ABSTRACT .... -

1. INTRODUCTION

1.1. Background Information ...........................................................................

1.2. Goals and Objectives .............................................................................. 14

\section{ENVIRONMENTAL POLICY AND LAW: GROWTH AND POLLUTION IN}

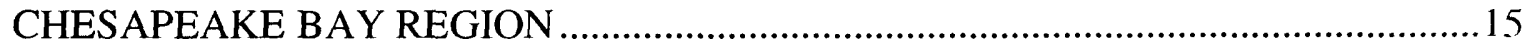

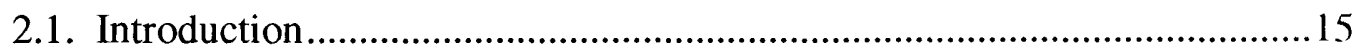

2.2. What is the Chesapeake Bay Program? ..................................................16

2.3. Water Quality and Land Use in the Bay Region .......................................21

2.4. Land, Growth and Stewardship Component of the Bay Program ..............25

2.5. Conclusions, Recommendations and Discussion ......................................32

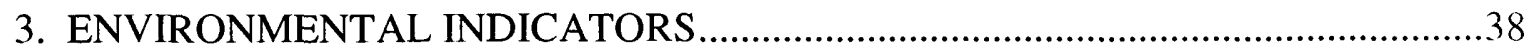

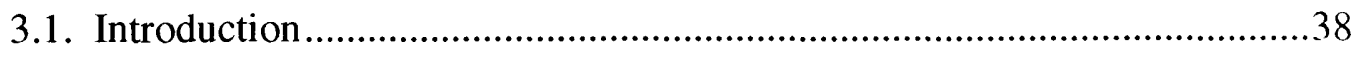

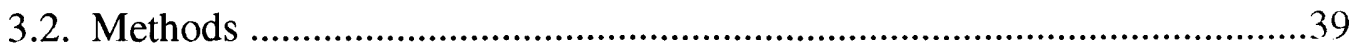

3.3. Environmental Results (BasinSim) ...........................................................66 


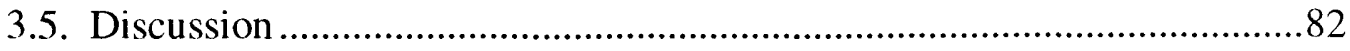

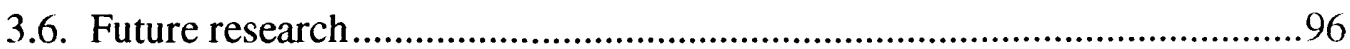

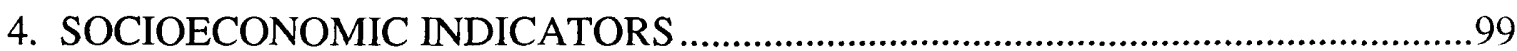

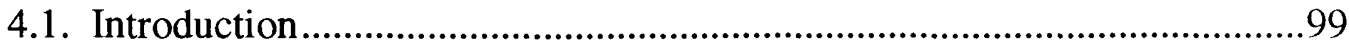

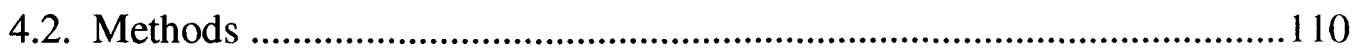

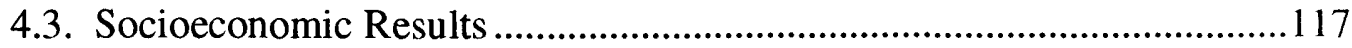

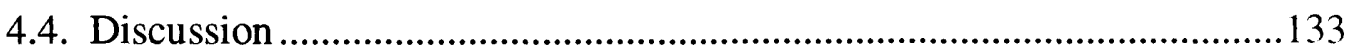

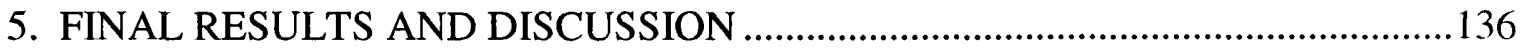

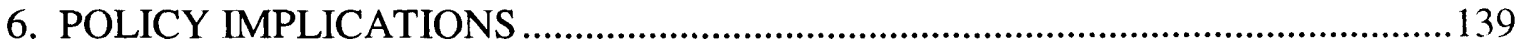

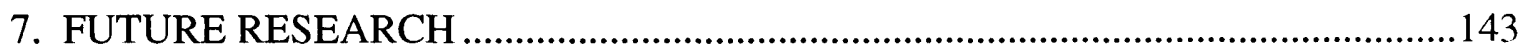

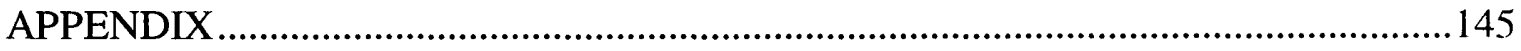

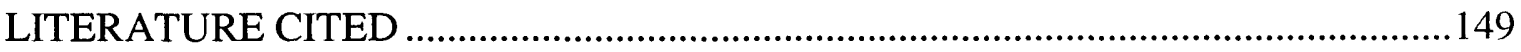

VITA 


\section{ACKNOWLEDGMENTS}

The support and guidance provided by my major professor James E. Kirkley is deeply appreciated. Many thanks also to the other members of my advisory committee: Ratana Chuenpagdee, James Perry, Carl Hershner, Mark Luckenbach and Carl Gustaf Lundin.

I wish to express my gratitude to the other members of the VIMS community for introducing me to marine science. Special thanks go to the Comprehensive Coastal Inventory group in the Department of Coastal and Ocean Policy.

Successful completion of this project would not have been possible without the financial support from Carl Hershner. Also thanks to the VIMS Graduate Student Association for providing additional funding (Craig Smith Memorial GSA mini grant) for my research.

I gratefully acknowledge the Virginia Institute of Marine Science, School of Marine Science, for their Fellowship award and Open Society Institute for providing me with the opportunity to study at the College of William and Mary.

I would have never made it this far without the help of my best friend Sosinna who encouraged and kept me motivated throughout the year.

Finally, thanks to my family who stayed on the other side of the Ocean while I was doing my research but whose presence and support I felt all the time. 


\section{LIST OF TABLES}

Table

Table 1-1. Chesapeake Bay submerged aquatic vegetation habitat requirements .10

Table 3-1. Segmentation of the Old Plantation Creek, Input file .42

Table 3-2. Segmentation of the Old Plantation Creek, Output file .43

Table 3-3. Land use in 4 scenarios: summary

Table 3-4. Changes in the input files (BasinSim) for Agriculture scenario .60

Table 3-5. Changes in the input files (BasinSim) for Forest scenario.

Table 3-6. Changes in the input files (BasinSim) for Golf Course scenario

Table 3-7. TPWQM input parameters 65

Table 3-8. Example output table from BasinSim (Baseline scenario, first segment) .......67

Table 4-1. County and State economic and social statistics comparison 104

Table 4-2. Predicted growth in Cape Charles and Northampton County due to Bay Creek

Development 109

Table 4-3. Tax ration and tax rate in the Northampton County. 124

Table 4-4. Tax revenues dynamics 126

Table 5-1. Nutrient and suspended solid loads to the O. P. Creek and anticipated Income and Employment indices under different development scenarios

Table 5-2. Average concentrations of nutrients and chlorophyll a in the Old Plantation Creek under different development scenarios 138 


\section{LIST OF FIGURES}

Figure

Figure 1-1. Eastern Shore map. Virginia portion of the Delmarva peninsular. .8

Figure 1-2. System's conceptual model............................................................... 12

Figure 2-1. Chesapeake Bay Watershed .............................................................. 17

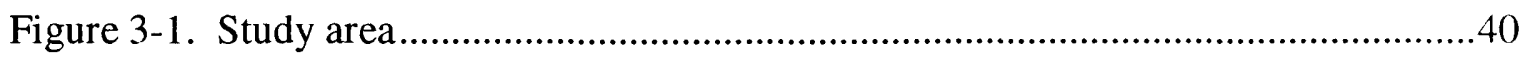

Figure 3 -2. Old Plantation Creek bathymetry map................................................ 41

Figure 3-3. Old Plantation Creek segmentation.................................................... 43

Figure 3-4. Old plantation Creek watershed land use and division into segments..........45

Figure 3-5. Old Plantation Creek land use and division into segments: Baseline scenario,

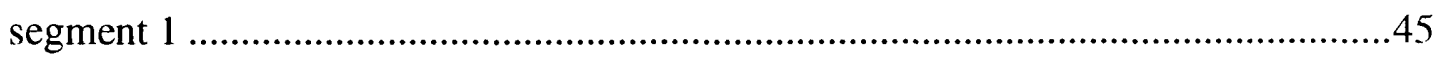

Figure 3-6. Proposed Bay Creek Golf Course/Residential Area Plan ..........................46

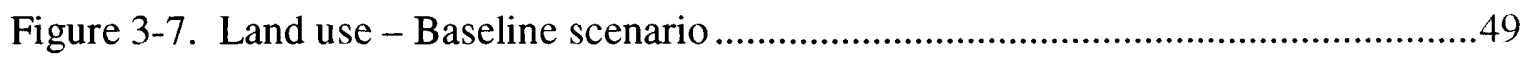

Figure 3-8. Land use - Agriculture scenario .........................................................49

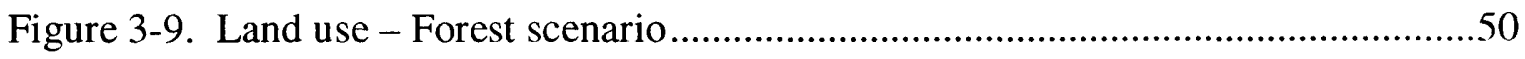

Figure 3-10. Land use - Golf Course scenario ....................................................50

Figure 3-11. Land use - Whole watershed, Old Plantation Creek ...............................51

Figure 3-12. Structure of the GWLF model ..........................................................53

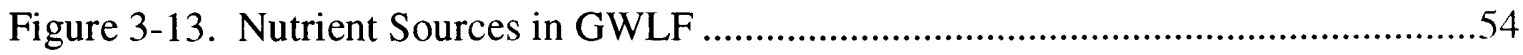

Figure 3-14. Monthly temperatures $\left({ }^{\circ} \mathrm{C}\right)$ for the Eastern Shore ....................................56

Figure $3-15$. Monthly daily precipitation $(\mathrm{cm})$ for the Eastern Shore ...........................56

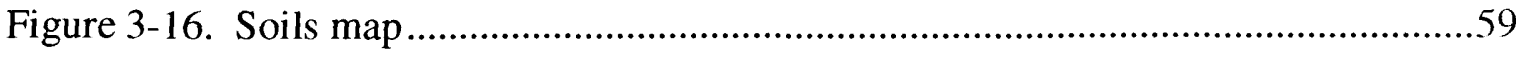

Figure 3-17. The flowchart of the TPWQM (from TPWQM users manual) ...................63 
Figure 3-18. Comparison of observed and predicted stream flow data

Figure 3-19. Yearly Nitrogen Loads from the Old Plantation Creek watershed under different scenarios.

Figure 3-20. Yearly Phosphorus Loads from the Old Plantation Creek watershed under different scenarios.

Figure 3-21. Monthly average (years 1989- 1995) nitrogen loads from Baseline scenario, segment 1 .70

Figure 3-22. Monthly total nitrogen loads: Baseline scenario, segment 1 .....................70

Figure 3-23. Monthly total nitrogen loads: Baseline scenario, segment 1 ....................71

Figure 3-24. Monthly Average (years 1989- 1995) Phosphorus Loads: Baseline scenario, segment 1 ) 71

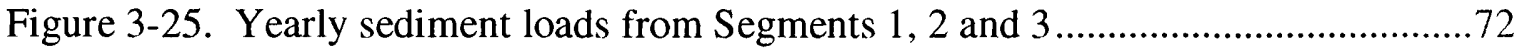

Figure 3-26. Monthly sediment loads from Segments 1,2 and $3 \ldots \ldots \ldots \ldots \ldots \ldots \ldots \ldots \ldots . . . \ldots . \ldots \ldots$

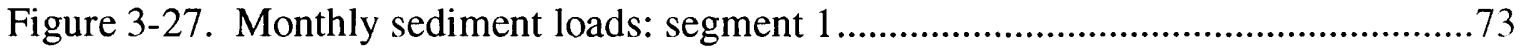

Figures 3-28, 3-29. Nitrogen concentrations in Baseline scenario: March and monthly ..74 Figures 3-30, 3-31. Phosphorus concentrations in Baseline scenario: March and monthly .74

Figure 3-32. Chlorophyll "a" concentrations in all scenarios in Old Plantation Creek....77

Figure 3-33. Dissolved inorganic nitrogen concentrations in all scenarios in O. P. Creek ........77

Figure 3-34. Dissolved inorganic phosphorus concentrations in all scenarios in Old Plantation Creek .....77

Figure 3-35. Chlorophyll "a" in March, Agriculture scenario (6 Years average) ...........78

Figure 3-36. Nitrogen in March, Agriculture scenario (6 Years average).......................78

Figure 3-37. Phosphorus in March, Agriculture scenario (6 Years average) ..................79 
Figure 3-38. Chlorophyll "a" concentrations (Mg/l) in Water Column in the Lower,

Middle and Upper Old Plantation Creek .80

Figure 3-39. Nitrogen Concentrations $(\mathrm{mg} / \mathrm{l})$ in Water Column in the Lower, Middle and Upper Old Plantation Creek 80

Figure 3-40. Phosphorus Concentrations (mg/l) in Water Column in the Lower, Middle and Upper creek

Figure 4-1. Counties with Agricultural Profile of Development (population N) ...........116

Figure 4-2. Counties with Forest Profile of Development (population N)....... 116

Figure 4-3. Baseline Scenario Population, Historic and Projected Number of People ... 118 Figure 4-4. Population forecast and historic data comparison with the forecast by holding out 6 history years 118

Figure 4-5. Baseline Scenario, Total Employment .120

Figure 4-6. Employment forecast and historic data comparison with the forecast 121

Figure 4-7. Baseline scenario per capita income, forecast and historic data 122

Figure 4-8. Baseline scenario per capita personal income, forecast and historic data comparison

Figure 4-9. Baseline Scenario, total income forecast and historic data 123

Figure 4-10. Total income forecast and historic data comparison. 123

Figure 4-11. Agriculture, Forest and Golf Course Scenarios Population 128

Figure 4-12. Agriculture, Forest and Golf Course Scenarios Total Employment 129

Figure 4-13. Personal Income (actual and constant dollars)

Figure 4-14. Agriculture, Forest and Golf Course Scenarios per capita income 130

Figure 4-15. Agriculture, Forest and Golf Course Scenarios Total Income 132 


\section{ABSTRACT}

The main reasons for continuing environmental degradation is the failure to deal with the socioeconomic pressures of development and failure to integrate environmental concerns in the process of development. Northampton County, located in the Eastern Shore of Virginia, is one of the few places on the East Coast of the United States that remains relatively undeveloped, but as more people are moving to the coastal zone it is expected that the region's population will increase considerably in the next decade. There is also an interest in economic development and urbanization coming from the side of local authorities and businesses. The purpose of this research was to assess management strategies and development perspectives of Northampton County, Virginia. Environmental law related to water pollution and land use issues in the Chesapeake Bay region is discussed. Both environmental and socioeconomic indicators were examined. The BasinSim and Tidal Prism Water Quality models were used to assess the impacts of land use on water ecosystems. Four development scenarios were created and compared. GIS was used as a tool for creating new scenarios and for conflict analysis.

Socioeconomic analysis was performed using forecasting techniques (regression, exponential smoothing). For the assessment of the impacts of environmental degradation, the habitat suitability model for submerged aquatic vegetation (SAV) was used.

The study of environmental law in the Chesapeake Bay region showed that there are many initiatives related to environmental protection. Sometimes the economic considerations drive the decision-making, but the existing regulations and laws try to preserve the integrity of the ecosystems. According to the socioeconomic indicators Northampton County is one of the poorest in the Commonwealth of Virginia. Unless some actions are taken, significant number of people will remain without jobs and enough money to sustain themselves and more people will leave the county. From investigated scenarios the Golf Course/Residential Area scenario would provide the most opportunities for local people to increase their wealth. Under Forest scenario as well as Baseline scenario the socioeconomic statistics would not improve significantly during the next 15 years. The environmental indicators (nitrogen, phosphorus, and suspended solids) showed that among all scenarios the Agriculture scenario would be the biggest polluter to the Old Plantation Creek ecosystem. Forest scenario would be the most pristine scenario. Pollutant loads would increase with increased human activities in the watershed. However, because of the impact of the Chesapeake Bay, water quality in the Old Plantation Creek would remain relatively steady in different scenarios. 


\section{ASSESSMENT OF DEVELOPMENT IMPACTS ON COASTAL ZONE:}

INTEGRATED APPROACH

NORTHAMPTON COUNTY, EASTERN SHORE, VIRGINIA 


\section{INTRODUCTION}

Humans play a special role in the ecosystem. We are responsible for understanding our place and function, and managing it sustainably. This responsibility is not only an ethical and a moral issue - it has to do with the fact that saving the environment actually means saving ourselves, including future generations, since we, as a biological species, are dependent on healthy ecosystems for survival.

In 1987, the Brundtland Commission defined sustainability as "development that meets the needs of the present without compromising the ability of future generations to meet their own needs" (United Nations, 1994). Many of the issues are global - from climate change and biodiversity, to human rights, world peace, and international security - and no one country can realize sustainable development on its own. Recognizing that sustainability is global, the nations of the world came together in Rio de Janeiro in 1992 for the United Nations Conference on Environment and Development. Together, they developed a new agenda for the 21 st Century, known as Agenda 21, and agreed to take concrete steps to implement it within their own borders and worldwide.

As an abstraction "sustainable development" is a long-term goal over which there is a broad and growing consensus. Establishment of this goal is fundamentally a social decision about the desirability of a survivable ecological economic system. It entails maintenance of (1) a sustainable scale of the economy relative to its ecological life 
support system; (2) a fair distribution of resources and opportunities, not only among the current generation of humans, but also between present and future generations and between humans and other species, and (3) an efficient allocation of resources that adequately accounts for natural capital. Most scientists agree that sustainable development is "an evolving process that improves the economy, the environment, and society, both today and over the long term." (Costanza, 1991; Turner et al., 1993;

Barnthouse et al. 1999)

Concerns about job creation, economic growth, or investment have often been considered apart from concerns about environmental quality or education, with less than optimal results. For example, efforts to further economic growth in a particular geographical region without adequate consideration of the region's environment, natural resources, and social character may lead to urban sprawl, the disintegration of inner city neighborhoods, pollution, or destruction of habitat. On the other hand, efforts to avoid any changes in natural habitat or the environment may hamper a region's ability to meet the economic and social needs and expectations of its residents. If we focus only on damage control, then we are likely to miss opportunities for innovation and new ways of thinking (Costanza, 1991).

An appropriate distinction of significance for sustainability is the one between growth and development. Growth refers to the quantitative increase in the scale of the physical dimension of the economy, the rate of flow of matter and energy through the economy, and the stock of human bodies and artifacts, while development refers to the qualitative improvement in the structure, design, and composition of physical stocks and 
flows, that result from greater knowledge, both of technique and of purpose (Turner et al. 1993; Costanza, 1991; Buck, 1996)

The conflict between land use and water quality is an emerging and fast growing issue for today scientists and managers. The issue is not new but the significance is just recently understood. For example, the Chesapeake Bay program was initiated to fight pollution in the region. The program officials are realizing that success in pollution reduction is dwindling and soon might be lost because of the threat of development (sprawl). The program is becoming a land use regulating agency. Managers have begun to understand that if we want to preserve the pristine nature of the Bay while maintaining a prosperous regional economy, the equation that we have to solve is getting more complex. The issue investigation should be performed and decisions made about the future of this area in an integrated manner. Different interest groups are fighting for different goals. The goal of the manager is to bring those different opinions together and find a mutually beneficial solution. This study attempted to achieve this goal.

\subsection{Background Information}

The Eastern Shore of Virginia is an 80-mile-long peninsula that encompasses about 696 square miles of land area with approximately $1 / 2$ of this land area draining into Chesapeake Bay. There are 17 localities within the Bay watershed of the Shore, including Accomack and Northampton counties and fifteen towns. The dominant land uses in the Bay watershed of the Shore are forest and agriculture, with several scattered industrial areas and denser development around the existing towns (Virginia Secretary of Natural Resources, 1999). 
The Eastern Shore is unique peninsula of the Chesapeake Bay because it is long and narrow, with numerous small watersheds that comprise a complex system of tidal creeks. The majority of these creeks are primarily influenced by tides with limited freshwater flows in the upper reaches. Groundwater influx, runoff from pulsed or stormrelated events and Bay mainstream water (Virginia Secretary of Natural Resources, 1999) characterize the water quality of these creeks.

Growth on the Eastern Shore is fairly steady, with much of the growth occurring as single-family residential growth as well as some additional commercial growth along Route 13 in both counties. As with other rural areas in the state, there is a trend towards conversion of agricultural land and forestland to more urban land uses, including residential development. Urban land uses, in the context of Eastern Shore, is relatively recent term and can include residential, commercial and industrial development. While large-scale development has not yet occurred on the Eastern Shore, construction of a 2000+-acre residential area/golf course (Bay Creek) began in the Cape Charles area. This type of large-scale development may occur more frequently on the Shore in the future as growth pressures increase from the north and south. Many of the Shore's new residents are retirees from northern states of the US (Virginia Secretary of Natural Resources, 1999).

The Eastern Shore Coastal Basin is still rural in nature, with most lands either forested $(51 \%)$ or used as agricultural crop land (38\%). Urban land uses are limited on the Eastern Shore and account for only 6 percent of the total land use. Water features account for an additional 4 percent. Nonpoint sources dominate the basin, meaning that most of the nutrient reduction effort that will be undertaken on the Eastern Shore will 
need to emphasize the management of pollution through the use of Best Management Practices (BMPs) on agricultural and urban lands. Point source reductions are not likely to be significant. The only public point source that is expected to have an increase in flow is the Cape Charles Sewage Treatment Plant (STP), which will have flow increases as a result of the development of Bay Creek. Another primary conduit for pollution on the Eastern Shore is ground water inflow to the creeks and streams that bisect the shore. Groundwater inflow may contribute considerable fresh water to the creeks and streams because of the unique physical characteristics of the Eastern Shore, which include high water tables and sandy and permeable soil (Virginia Secretary of Natural Resources, 1999).

The poultry producing agribusiness is a rapidly growing sector on the Eastern Shore. Poultry operations will need to be evaluated in terms of innovative technologies and methodologies to best implement management practices. Similarly, plasticulture crops (the crops are covered with plastic in order to keep the moisture and fertilizers on the ground) are on the increase and while this agribusiness has proven beneficial to crop production and yields, its impacts need to be investigated (Virginia Secretary of Natural Resources, 1999).

As a case study we chose Northampton County and the town of Cape Charles (Fig. 1-1). Cape Charles is located between Kings and Old Plantation creeks on the Bay Side of the Eastern Shore. Until recently the area (except Cape Charles itself) remained undeveloped and was mainly agricultural and forest land.

The Town of Cape Charles was established in 1884 when the New York, Philadelphia and Norfolk Railroad extended its line southward through the Delmarva 
Peninsula. Cape Charles was established as the railroad's southern terminus from which steamships carried passengers and freight to Norfolk (Cape Charles/Northampton County Chamber of Commerce, 1998).

The whole town was built to house railroad executives as well as for the expanding merchant class. Cape Charles lost its commercial rail significance when the Chesapeake Bay Bridge-Tunnel was built. People lost their jobs and left the town. Recently the town has gradually started to revive. Business is returning and the prices of land and buildings are increasing fast.

Some of this growth might be attributed to revival of local businesses and also to developments that started recently. Two of the major ones are Bay Creek development and Sustainable Technology Park. Bay Creek development surrounds Cape Charles on three sides and will occupy 1700 acres. Developers are building two golf courses to the south of the town. To the north, in Kings Creek, a marina is proposed. Several residential areas will be built around Cape Charles adding 1500 home units in 12 years. New development should attract retired people and also people looking for their summer/second home. According to developers the construction should improve the quality of life and encourage economic growth (Bay Creek, 2000). 


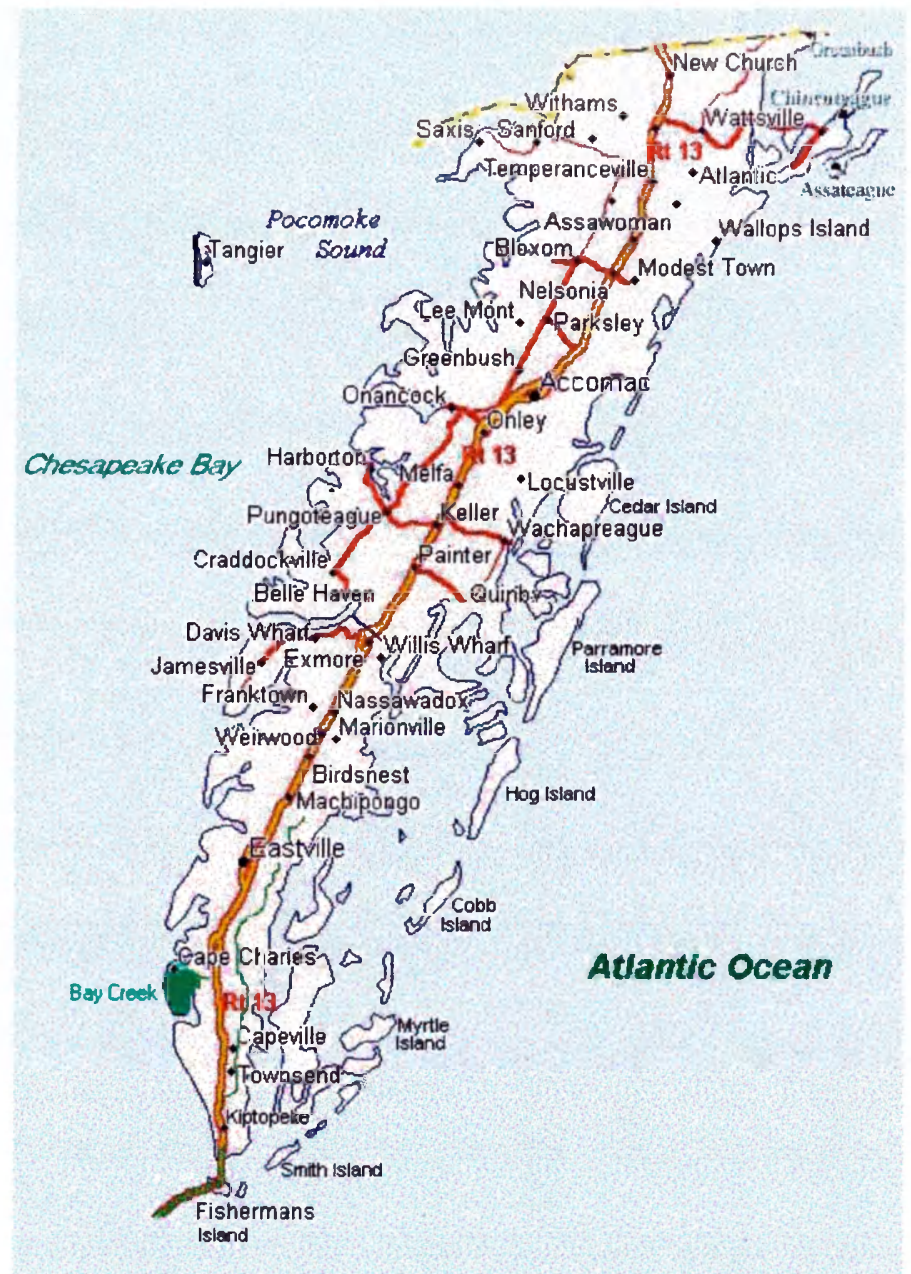

Figure 1-1. Eastern Shore map. Virginia portion of the Delmarva peninsular.

\section{Environmental Indicators}

Development impact assessment was performed using environmental indicators.

One of the indicators proposed for the use in this study was clams. Cultured hard clams (Mercenaria mercenaria) are the most valued aquaculture crop in Virginia. In 1993, cultured hard clams were estimated by the Virginia Agricultural Statistics Service to have had gross sales in excess of $\$ 11$ million (Newton, 1995). Clams are extremely tolerant of poor water quality and can grow and survive in areas polluted by industrial and domestic waste (Malinovsky, 1986), but the biggest concern is fecal coliform levels. It is forbidden 
to sell clams raised in waters where the fecal coliform median (MPN) in the water exceeds $70 / 100 \mathrm{ml}$ (Shellfish, 1990). Later we found that it is too early to incorporate in study the prediction of fecal coliform levels because it depends on many factors and there are no reliable methods for their investigation. For the other environmental indicator used in our study, submerged aquatic vegetation (SAV), there are established habitat suitability indexes, and models are available for predicting those indexes.

SAV plays an important ecological role in the aquatic environment by: (1) providing food and habitat for waterfowl, fish, shellfish and invertebrates; the grasses serve as nursery habitat for many species of fish and blue crabs; (2) producing oxygen in the water column as part of the photosynthetic process; (3) filtering and trapping sediment that can cloud the water and bury bottom-dwelling organisms, such as oysters; (4) protecting shorelines from erosion by slowing down wave action; and (5) removing excess nutrients, such as nitrogen and phosphorus, that could fuel unwanted growth of algae in the surrounding waters (Chesapeake Bay Program. 1999).

Eelgrass (Zostera marina) is the dominant submerged macrophyte in the mesohaline and polyhaline regions of the Chesapeake Bay. Historically, extensive seagrass beds covered the shoal area of less than $2 \mathrm{~m}$ depths along the Bay and its eastern and western shore tributaries. Decline in abundance of $Z$. marina occurred through the bay in the early 1970's (Moore et al., 1996).

The decline of seagrass and other submerged vascular plant communities worldwide has been attributed to poor habitat conditions. Dennison et al. (1993) concluded that in Chesapeake Bay water quality conditions sufficient to support survival, growth, and reproduction of submerged aquatic vegetation to a water depth of one meter 
below MLW are: light attenuation less than $2 \mathrm{~m}$, total suspended solids less than $15 \mathrm{mg} / \mathrm{l}$, chlorophyll-a less that $15 \mu \mathrm{g} / \mathrm{l}$. Nitrogen and phosphorus levels are also important (Table $1-1)$.

Table 1-1. Chesapeake Bay submerged aquatic vegetation habitat requirements Salinity regimes are defined as tidal fresh $=0-0.5 \%$ oligohaline $=0.5-5 \%$, mesohaline $=5-18 \%$, polyhaline $=$ more than $18 \%$ (Dennison et al., 1993)

\begin{tabular}{|l|l|l|l|l|l|}
\hline Salinity regime & $\begin{array}{l}\text { Light } \\
\text { attenuation } \\
\text { coefficient } \\
\left(\mathrm{K}_{\mathrm{d}}, \mathrm{m}^{-1}\right)\end{array}$ & $\begin{array}{l}\text { Total } \\
\text { suspended } \\
\text { solids }(\mathrm{mg} / \mathrm{l})\end{array}$ & $\begin{array}{l}\text { Chlorophyll a } \\
(\mu \mathrm{g} / \mathrm{l})\end{array}$ & $\begin{array}{l}\text { Dissolved } \\
\text { inorganic } \\
\text { nitrogen } \\
(\mathrm{mg} / \mathrm{l})\end{array}$ & $\begin{array}{l}\text { Dissolved } \\
\text { inorganic } \\
\text { phosphorus } \\
(\mathrm{mg} / \mathrm{l})\end{array}$ \\
\hline Tidal freshwater & $<2.0$ & $<15$ & $<15$ & - & $<0.02$ \\
\hline Oligohaline & $<2.0$ & $<15$ & $<15$ & - & $<0.02$ \\
\hline Mesohaline & $<1.5$ & $<15$ & $<15$ & $<0.15$ & $<0.02$ \\
\hline Polyhaline & $<1.5$ & $<15$ & $<15$ & $<0.15$ & $<0.02$ \\
\hline
\end{tabular}

Nutrient enrichment can promote phytoplankton growth, which increases turbidity. Dissolved substances further increase water column light attenuation, especially in estuarine areas. Decreased light availability can have adverse effects on $Z$. marina photosynthesis, growth, community structure, and ultimately long-term survival. With increased nutrient loading, seagrasses have been replaced by macrophytes in some systems. Nutrient enrichment has also been related to increased growth of epiphytes on macrophyte shoots and leaves. Additionally, there is some evidence that elevated concentrations of water column nitrate may be toxic to some submerged macrophytes (Moore et al. 2000; Orth et al. 1984).

In some cases it may be the peak and not necessarily the long-term average concentrations of nutrients, which determines the stress level experienced by SAV. (Moore et al., 2000; Moore et al., 1996; Moore et al., 1997). 
The background for using SAV as an environmental indicator comes from the Eastern Shore Coastal Basins Tributary Nutrient Reduction Strategy (1999). In 1999 Eastern Shore stakeholders agreed to a long-term living resource goal:

Increase the areas and density of Submerged Aquatic Vegetation throughout the Eastern Shore tidal creeks and embayment to historic levels to enable the return of abundant and diverse fish and shellfish populations, which, in turn, will help to sustain and improve local economies (Virginia Secretary of Natural Resources, 1999).

\section{Project Description, Model Creation, and Scenarios}

The general idea of the overall research model is that land use is affecting water quality in adjacent creeks. That in turn affects the SAV. The relationship between land use and water quality was investigated using the BasinSim model (BasinSim, 2000) which takes into consideration different parameters such as soils, land cover, vegetation type and others (see description in section 3.2.) and determines what are the pollutant loads to the creek. Tidal Prism Water Quality Model (TPWQM) in turn takes the loads information and calculates what is the concentration of pollutant in the creek. The equation includes water volume, geometry of the creek, biological processes in the creek (see description in section 3.2.). GIS was used for land use information manipulation, also for creating new scenarios for the environmental part of the research. All the results go to the final Impact assessment table where the results were put together with the socioeconomic parameters. Socioeconomic analysis was performed using forecasting techniques (regression, and different types of exponential smoothing). Creation of different scenarios (Agriculture and Forest) was performed using information from the 
counties that have agriculture or forest development pattern. In the case of proposed development the cost benefit analysis data derived by developers were used for comparison. The overall research model is shown in Figure 1-2.

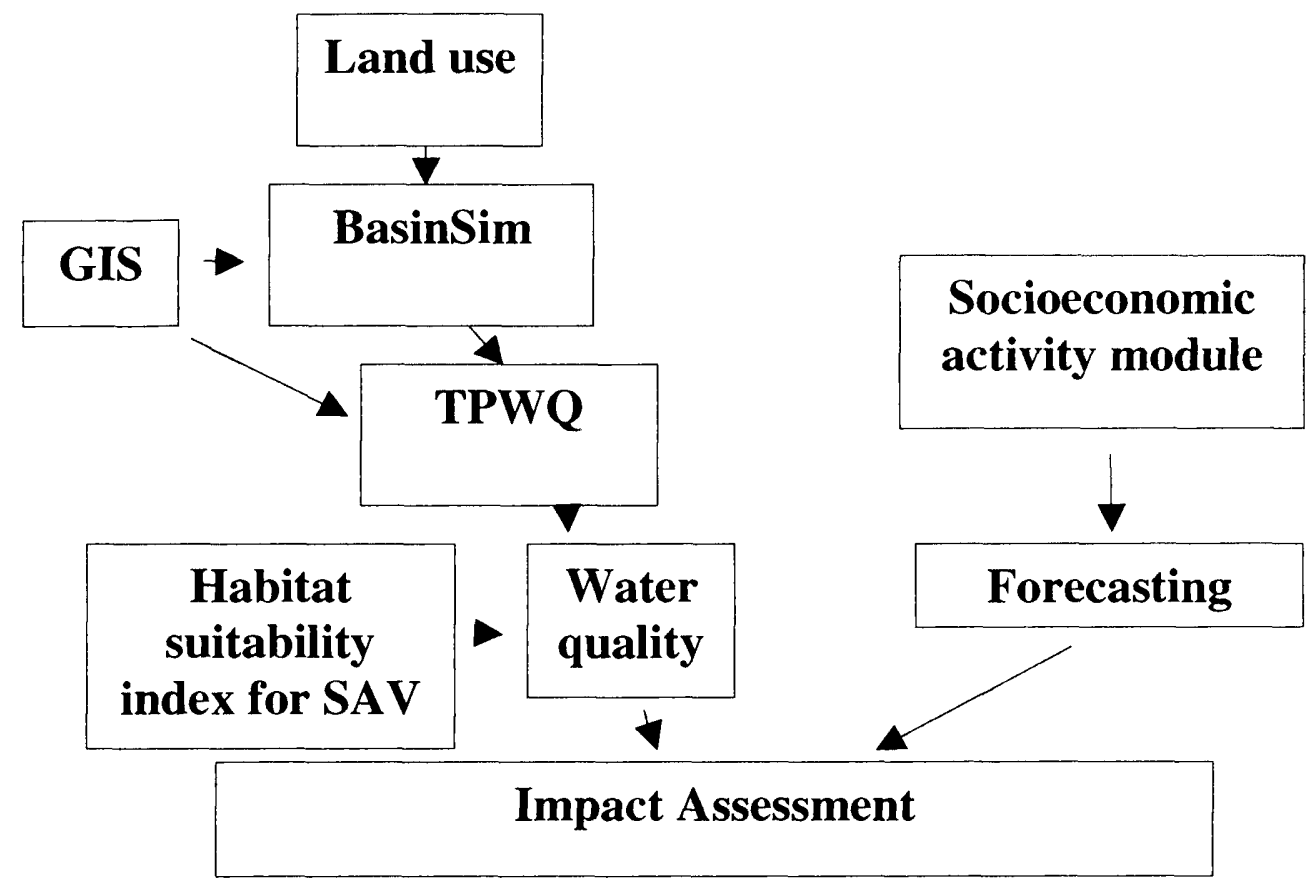

Figure 1-2. System's conceptual model

In order to see available options for the development, alternative scenarios were created:

1. Baseline scenario - year 1989 (based on Proposed Bay Creek Development watershed, part of the Old Plantation Creek watershed) (Figure 3-4)

2. Agriculture scenario

3. Forest scenario

4. Golf Course/Residential Area scenario (Proposed Bay Creek Development) (For full description of scenarios, concepts and creation see section 3.4.) 
The thesis is in three parts: the first part provides information about environmental law and the Chesapeake Bay Program as an example of partnership between states. Examples of different activities are presented. Also, existing water pollution control, land use regulations and laws are analyzed. The study showed that the goals are high and there is a lot of progress achieved in preserving the ecosystems.

The second part (Environmental Indicators) investigates alternative scenarios and possible impacts of development in the Eastern Shore. Through the modeling exercise the pollutant loads (nutrients and suspended solids) were calculated and evaluated. Final concentrations of the pollutants in Old Plantation Creek were calculated and compared with the SAV habitat suitability indexes. The comparison did not show that water quality would be deteriorated in any of the scenarios. The reason for that might be the overwhelming influence of the Chesapeake Bay on the local Old Plantation Creek where the amount of the incoming tide water is almost equal to the residing water in the creek. The segmentation analysis showed that there is indeed a difference in different segments of the creek in pollutant concentrations: higher upstream (lesser impact of the Bay) higher the concentration.

In the third part of the thesis socioeconomic indicators were examined. The status of Northampton County economic performance was evaluated and projected into the future under different development scenarios. The results showed that the existing situation (Baseline scenario) is not promising any progress in the regions economic development. Compared to the other scenarios, Agriculture and Forest scenarios would bring moderate growth to the region with higher numbers for agricultural profile development. Golf Course scenario would bring the highest salaries and employment to 
the county. In the case of socioeconomic indicators the region was different than the one investigated in the second (environmental) part because the smallest and most convenient (data availability) unit is the county level. So the growth was calculated for the Cape Charles area and the results added to the Baseline scenario projections. In the case of environmental indicators the smallest unit is the watershed (Old Plantation Creek watershed). As the development will occur only on one side of the creek the numbers were calculated for that one side of the creek and then added to the whole watershed results. Under different scenarios it was assumed that the whole watershed land use is not changing and only the proposed development area is different in different scenarios.

\subsection{Goals and Objectives}

This study had these goals and objectives:

- Assess and evaluate the scale of human activities (alternative development) plans from a sustainable development perspective

- Develop and test an analytical framework for Integrated Coastal Zone Management (incorporate into the research environmental, social and economic aspects of planning and management)

- Provide the best available information on land uses, nutrient and sediment loads, water quality conditions and management practices. To inform managers, planners and citizens of the factors that are or will be affecting the water quality of the creeks and streams 


\section{ENVIRONMENTAL POLICY AND LAW: GROWTH AND POLLUTION IN CHESAPEAKE BAY REGION}

\subsection{Introduction}

Water pollution has been a big issue in the Chesapeake Bay region and around the world. There have been many measures proposed and used to fight nutrient enrichment and other kinds of pollution. Recently, it has been realized that water quality in the future would not be protected by conservative means only, including regulation of point source pollution or controlling fertilizer application to the farm fields. Some of the pollution reduction progress has been lost already due to rapidly changing land use practices and uncontrolled and improperly planned development. New measures have to be adopted and implemented.

The report, Keeping Our Commitment: Preserving Land in the Chesapeake Watershed (Chesapeake Bay Commission et al., 2001), prepared by Chesapeake Bay Commission and The Trust for Public Land conveys that the accelerated consumption of open land is the Chesapeake Bay region's biggest environmental challenge. How we treat the land in the watershed profoundly influences water quality in the Bay. That in turn determines the abundance and health of natural living resources and hence, the general health of the ecosystem. Environmental Law is a tool for reduction of environmental degradation and encouragement of sustainable development. 
In the first section of this chapter, Chesapeake Bay Program activities are observed. In the second section, water pollution and land use conflict are described and issues of sprawl are discussed. The last section summarizes the findings of the chapter and gives suggestions on how the program could be more effective. The Chesapeake Bay Program was chosen as the initiative most appropriate to scope with the pollution reduction fight. Every locality is influenced by regulations accepted by the program. There might be different levels from which to observe the changes brought by law and policies in the region, but to our mind the program level is the most appropriate, because the decisions made on this level seem to make a difference in the health of the whole region. For example every state could be analyzed separately, but probably a single state's efforts would not greatly affect the health of the Bay.

\subsection{What is the Chesapeake Bay Program?}

The Chesapeake Bay Program is a regional partnership that has been directing and conducting the restoration of the Chesapeake Bay since the signing of the 1983 Bay Agreement. The Bay Program partners include the states of Maryland, Pennsylvania and Virginia and the District of Columbia; the Chesapeake Bay Commission, a tri-state legislative body; the Environmental Protection Agency, representing the federal government; and participating advisory groups. 


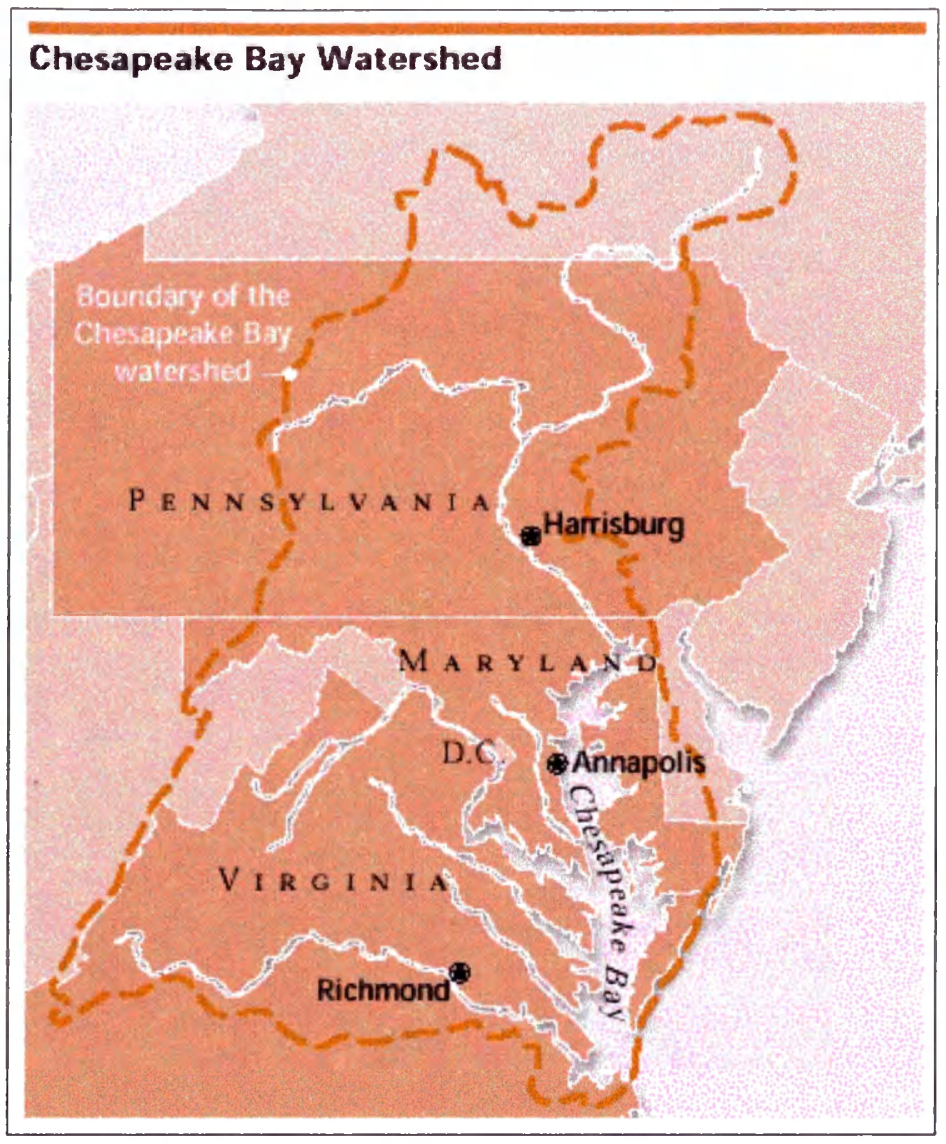

Figure 2-1.

\section{Chesapeake Bay}

Watershed

(see dashed line) and states participating in the Chesapeake Bay Program (from Keeping Our Commitment..., 2001)

As the largest estuary in the United States (Fig. 2-1) and one of the most productive in the world, the Chesapeake was the nation's first estuary targeted for restoration and protection. In the late 1970s, scientific and estuarine research on the Bay pinpointed three areas requiring immediate attention: nutrient over-enrichment, dwindling underwater bay grasses, and toxic pollution ${ }^{1}$.

Examples of the initiatives launched by the Bay program include a watershedwide phosphate detergent ban, the introduction of agricultural best management practices, biological nutrient removal at wastewater plants, and a public education campaign, 
highlighting the role each of the watershed's 15 million residents must play in the restoration.

In the 1987 Chesapeake Bay Agreement, the Executive Council set a goal to reduce nutrients (nitrogen and phosphorous) entering the Bay by $40 \%$ by the year 2000 . Achieving a $40 \%$ nutrient reduction will ultimately improve the oxygen levels in the Bay waters and encourage aquatic life to flourish ${ }^{2}$. In the 1992 Amendments of the Agreement, the Bay Program partners agreed to maintain the $40 \%$ goal beyond the year 2000 and to attack nutrients at their source: upstream in the Bay's tributaries. As a result, Pennsylvania, Maryland, Virginia, and the District of Columbia began developing tributary strategies to achieve the nutrient reduction targets ${ }^{3}$.

Later in the progress of restoration, Chesapeake Bay Program participants started to understand the importance of watersheds and that the local action and strategies in these watersheds could best be implemented by local authorities. The 1995 Local Government Partnership Initiative $e^{4}$ engaged the watershed's 1,650 local governments in the Bay restoration effort. The development of Nutrient Reduction Strategies for the Bay's tributaries has brought the Program further upstream and has created a closer association with local governments. The Executive Council followed this Initiative in 1996 by adopting the Local Government Participation Action Plan and the Priorities for

\footnotetext{
${ }^{1}$ Chesapeake Bay Program, 1983 Chesapeake Bay Agreement (December 9, 1983) at http://www.chesapeakebay.net/pubs/1983ChesapeakeBayAgreement.pdf

${ }^{2}$ Chesapeake Bay Program, 1987 Chesapeake Bay Agreement (4 March 1996) at http://www.chesapeakebay.net/pubs/1987ChesapeakeBayAgreement.pdf

${ }^{3}$ Chesapeake Bay Program, Chesapeake Executive Council, DIRECTIVE No. 93-1, Joint Tributary Strategy Statement (March 4, 1996) at http://www.chesapeakebay.net/pubs/473.pdf

${ }^{4}$ Chesapeake Bay Program, Chesapeake Executive Council, DIRECTIVE 95-1 Local Government

Partnership Initiative (November 30, 1995) at http://www.chesapeakebay.net/pubs/891.pdf
} 
Action for Land, Growth and Stewardship in the Chesapeake Bay Region ${ }^{5}$, to address land use management, growth and development, stream corridor protection, and infrastructure improvements. One of the more significant and restricting regulations was issued in 1996 by the Executive Council: the Riparian Forest Buffers Initiative ${ }^{6}$ increased the Bay program's commitment to improve water quality and enhance habitat. The new goal calls for restoring 2,010 miles of riparian buffers on the streams and shorelines in the watershed by the year 2010. This initiative raised a lot of discussion in the states as to whether the regulation is not too strict and is not violating property rights of the landowners and developers.

In 1997, the Executive Council renewed its commitment to the $40 \%$ nutrient reduction goal, acknowledging that it had to accelerate efforts. A Bay Program study had concluded that the goal for phosphorus reduction would be met by the year 2000; however, the goal for nitrogen would not be met unless efforts were intensified. Other directives signed in 1997 focused on wetland protection and restoration and the development of a Bay Program Community Watershed Initiative ${ }^{7}$. By the Watershed Initiative the Executive Council recognized the significance of local communities involvement in the restoration efforts. This would strengthen and coordinate actions to protect the living resources, ensure clean and healthy water, minimize the impacts of land use and development, provide quality environmental education, allow for public access to

\footnotetext{
${ }^{5}$ Chesapeake Bay Program, Priorities for Action for Land, Growth and Stewardship in the Chesapeake Bay Region (1996) at http://www.chesapeakebay.net/overview.htm

${ }^{6}$ Chesapeake Bay Program Chesapeake Executive Council, DIRECTIVE NO. 94-1, Riparian Forest

Buffers (October 14, 1994), http://www.chesapeakebay.net/pubs/326.pdf

${ }^{7}$ Chesapeake Bay Program, Chesapeake Executive Council, DIRECTIVE NO 97-3, Community Watershed Initiative (October 30, 1997), at http://www.chesapeakebay.net/pubs/824.pdf
} 
the Bay and its tributaries, and encourage public participation in the restoration campaign through cooperative efforts of the Bay program partners. Local governments, watershed groups, and citizens were recognized as "key partners" in the sustained implementation of the Tributary Strategies and in the achievement of the broader bay program goals and commitments.

\section{Chesapeake 2000 Agreement}

The latest Chesapeake Bay agreement was signed on June 28, 2000. The Bay agreement, Chesapeake 2000: $A$ Watershed Partnership ${ }^{8}$ will guide the next decade of restoration in the Chesapeake Bay watershed. By the 2000 Agreement, the participating parties committed to nurture and sustain a Chesapeake Bay Watershed Partnership and to achieve the goals set forth in the document. Some of these goals include, 1) the promotion and achievement of sound land use practices which protect and restore watershed resources and water quality; 2) the maintenance of reduced pollutant loading of the Bay and its tributaries; and 3) water quality protection and restoration in order to achieve and maintain the water quality necessary to support the aquatic living resources of the Bay and its tributaries.

The Chesapeake 2000 agreement is the latest and also most controversial of all previous bay program agreements. It is designed to protect the health of the ecosystem and humans but it also raises a lot of questions about whether it is implementable and whether it is not contradictory with existing rules and laws. The other thing is that the

\footnotetext{
${ }^{8}$ Chesapeake Bay Program, Chesapeake 2000: A Watershed Partnership, (June 28, 2000) at http://www.chesapeakebay.net/agreement.htm
} 
implementation will cost a lot of taxpayer's money. More often we hear that the regulations are restricting people's rights to do with their land what they want, they are preventing development in critical areas such as Virginia's Eastern Shore, where 30 percent of people live under the line of poverty (Northampton County Board, 1994) and the growth is necessary for their well-being.

Now that we have a better understanding of the Chesapeake Bay Program the following section will further observe related issues of pollution and land use. Pollution reduction strategies through the conservation of land will be discussed. Different states will be presented as examples with the emphasis on success and failures.

\subsection{Water Quality and Land Use in the Bay Region}

Nitrogen and phosphorus, which are essential for life, are virtually everywhere. In the Chesapeake Bay, these vital nutrients have become villains. When waterways are flooded with nutrients, algae can bloom. This green blanket of slime shields sunlight from reaching underwater plants, and takes up life-sustaining oxygen. The earlier mentioned bay program's 40 percent nutrient reduction strategy became a public barometer for judging the success of the overall bay cleanup. According to Federal statistics, there was a 16 percent reduction in nitrogen and 27 percent reduction in phosphorus. These reductions are well below the 40 percent target. Only the District of Columbia, the poorest of the cleanup partners, achieved its target (Associated Press, March 13, 2001; Harper, March 11, 2001).

Virginia, Maryland and Pennsylvania have all missed their target, despite spending hundreds of millions of dollars on upgrading sewage treatment plants, curbing 
urban runoff, fixing leaky septic systems, and assisting farmers to contain soil and fertilizers. Nonetheless, officials with the U.S. Environmental Protection Agency's Chesapeake Bay Program, which steer the cleanup, say much progress has been made since 1987. More progress is pending as dozens of sewage plants in Virginia and Maryland are expected to complete renovations in the next two years (Harper, March 11, 2001). But the Program gained ground at a time when hundreds of thousands of people moved into the Bay watershed, bringing new environmental stresses in the form of more homes, roads, sewage lines, lawn chemicals, pets and car. That was one of the reasons why the $40 \%$ goal was not achieved in time (Harper, March 12, 2001).

Some scientists, environmentalists and government watchdogs are not as impressed by the progress of the Program. They say the three states could have reached the centerpiece goal but lacked the political will to do so (Harper, March 11, 2001, Harper, March 12, 2001). In Virginia, political leaders pushed volunteerism and incentives instead of tougher standards and regulations. Furthermore, Virginia only began funding sewage-plant upgrades and other nutrient controls in 1997, a decade after Maryland started. And now, with Virginia belatedly moving toward its goal, continued funding for these improvements faces an uncertain future as Governor Jim Gilmore cut costs to make room for his promised car-tax relief (Harper, March 11, 2001, Harper, March 12, 2001). One more problem is that the Federal Government, in tackling nutrient pollution, so far has largely left the Bay states alone. However, it has offered technical advice and some gentle arm-twisting. 
One of the new approaches to reduce pollutant loads is the Total Maximum Daily Load $^{9}$ (TMDL). A TMDL study is required when a waterway is declared "impaired," or failing on at least one water-quality standard. Such a study forces a state to identify underlying causes for violations and fix them on a schedule. Large sections of the Bay in Virginia and Maryland are classified as impaired because of low oxygen conditions. The EPA has given both states until 2011 to find a remedy or face possible sanctions. Some critics of TMDL really feel that it has spawned too many lawsuits (Springston, 2001).

\section{Polluted Rivers}

Environmental groups sued the EPA in 1998, claiming Virginia's cleanup plans weren't being developed fast enough. The EPA settled the suit by agreeing to a consent decree - a court order - that set firm deadlines for developing the plans. This means 648 plans must be developed for Virginia's 600 polluted river segments by 2011 . (Each plan lays out a way to reduce a single pollutant, such as fecal bacteria or mercury. Some rivers are contaminated by more than one pollutant, so there will be more plans than polluted waters.) It takes several months to develop one plan. So far about a dozen have been completed (Springston, 2001). Making plans for cleaning Virginia's polluted rivers will cost taxpayers more than $\$ 59$ million. Actually cleanup of the waterways will cost

\footnotetext{
${ }^{9}$ A TMDL or Total Maximum Daily Load is a calculation of the maximum amount of a pollutant that a water body can receive and still meet water quality standards, and an allocation of that amount to the pollutant's sources. States, Territories, and Tribes set water quality standards. They identify the uses for each water body, for example, drinking water supply, contact recreation (swimming), and aquatic life support (fishing), and the scientific criteria to support that use. A TMDL is the sum of the allowable loads of a single pollutant from all contributing point and nonpoint sources. The calculation must include a margin of safety to ensure that the water body can be used for the purposes the State has designated. The calculation must also account for seasonable variation in water quality. The Clean Water Act, section 303 , establishes the water quality standards and TMDL programs (can be accessed at http://www.epa.gov/owow/tmdl/intro.html\#definition)
} 
roughly $\$ 300$ million more. Those costs don’t even include the roughly $\$ 275$ million needed to the troubled Chesapeake Bay. The cost of the cleanups in Virginia is estimated for the first time in a report prepared by the state Department of Environmental Quality and other agencies at the request of the 2000 General Assembly. About $\$ 18.2$ million in state and federal money appears to be available (Roth, 2001). According to the Chesapeake Bay Foundation group this happened because the states were delaying considering the issues related to pollution. State scientists consider 3,770 miles of rivers "impaired," or polluted. That is 41 percent of the river stretches that Virginia monitors. Most of the rivers are being polluted not by just big factories but also by fertilizer, manure, dirt and other contaminants that run off farms, parking lots and suburban yards during rainstorms (Roth, 2001, Springston, 2001). It is important to note that Virginia, like most states, has no standards for either nutrients or sediment in our waterways; if it did, there would likely be many more waters designated as impaired.

The other reason why the water quality kept declining over time was due to population growth. In Virginia alone, there are now about 7 million people instead of 4.7 million, as at the time of the Clean Water Act issuance. The amount of developed land has doubled since the early 1970s, and Virginians currently drive their vehicles more than twice as many miles per year (Roth, 2001). According to the Virginia Department of Environmental Quality (DEQ) nutrient runoff $^{10}$ linked to sprawling suburban development continues to rise - by 30 percent for nitrogen and 26 percent for phosphorus (Harper, March 11, 2001, Harper, March 12, 2001). While runoff pollution from these

\footnotetext{
${ }^{10}$ Nutrient runoff pollution occurs when rainfall washes pollutants off the land into streams and rivers. The pollutants range from sediment to nutrients to toxic chemicals. The land uses that contribute most to runoff pollution are urban and suburban development and agriculture
} 
land uses can be controlled, it costs money and requires that land uses be modified (Roth, 2001). For example, farmers may not be able to cultivate their fields right up to the stream, but rather, must leave a buffer area to control the movement of pollution from fields into the stream.

For Virginia, DEQ's bay cleanup managers expect a "big drop" in nutrients by the end of 2002 if funding is available to finish overhauling several plants along the Potomac and Shenandoah rivers (Harper, March 11, 2001, Harper, March 12, 2001). Other DEQ officials believe that Virginia could have resolved its nutrient issue with a single decree: by adopting a standard for nitrogen, that of 8 milligrams per liter of water, which all treatment plants would have had to meet. The state did not approve such a regulation, preferring to offer grants and other incentives to plant owners. Other states finished similar programs earlier.

\subsection{Land, Growth and Stewardship Component of the Bay Program}

As we saw in the previous section pollution is a very big issue in the Chesapeake Bay region. According to the Bay program officials, growth might be the challenge which we have to overcome in order to achieve the goal of nutrient reduction. According to the report, Keeping Our Commitment: Preserving Land in the Chesapeake Watershed (Chesapeake Bay Commission et al., 2001), the land-to-water ratio is sixteen to one in the region: 4,000 square miles of water surface and 64,000 square miles of watershed. Our treatment of the land heavily influences the quality of the water. Hence, land-use decisions may prove to be the single most important factor in the success or failure of 
efforts to restore and protect the Chesapeake Bay. The earlier-mentioned study (Chesapeake Bay Commission et al., 2001), builds upon the landmark Chesapeake 2000 Agreement signed last summer by governors of Pennsylvania, Maryland and Virginia, in which the states pledged to save a combined 40 million acres of the Bay watershed by the end of the decade (Associated Press, 2001, Virginian-Pilot, February 26, 2001).

The U.S. Geological Survey report (2000) shows that farming and livestock continue to be the dominant sources of animal wastes, fertilizers and other nutrients that degrade water quality, but polluted runoff from urban and suburban areas is increasing as development spreads (Latane, 2001). Preserved land ${ }^{11}$ does help slow the flow of runoff into the Bay and absorbs pollutants (McCord, 2001).

According to Federal studies the amount of developed land increased 15 percent in Virginia between 1992 and 1997. The development occurred even more rapidly in Maryland and Pennsylvania: 16 percent and 17 percent respectively (Keeping Our Commitment..., 2001). The Chesapeake Bay region lost an area more than three times the size of the District of Columbia to sprawl during each year in the mid-1990s.

\section{Land Preservation Goals}

Each of the three bay states has agreed to slow the pace of land conversion and to preserve 20 percent of the land in the watershed by year 2010 . However, only two of the states, Pennsylvania and Maryland, have devoted any real money to the effort. Of the

\footnotetext{
11 Preserved land is defined as land that is permanently protected from development with a perpetual conservation or open space easement or fee ownership, held by a federal, state, or local government or nonprofit organization for natural resource, forestry, agriculture, wildlife, recreation, historic, cultural, or open space use, or to sustain water quality and living resource values (Blankenship, 2001)
} 
three states, Maryland is the only one with an integrated program that combines smart growth with smart conservation (McMahon, 2001). From 1992 to 1999, Pennsylvania spent about $\$ 188$ million to save land in the watershed, much of it through farmland preservation programs. Maryland spent about $\$ 305$ million and Virginia spent $\$ 23.5$ million during the same period (Chesapeake Bay Commission et al., 2001). Current funding programs- a mix of state, federal and private sources- can cover about half the cost of saving the land needed to reach the goal. And even that assumes the average cost of $\$ 2,250$ an acre in the 90 s will be sufficient over the next 10 years (Baltimore Sun, 2001).

Between 1992 and 1999, more than 90,000 watershed acres were protected within the Commonwealth of Virginia, some 80 percent of which were protected through the donation of land and easements to private conservation organizations and the Virginia Outdoors Foundation. The remaining 18,000 acres were protected by state and Federal funds (Lazaroff, 2001). But there is a question what to consider the preserved land. For example the biggest disparity is with Department of Defense lands. Virginia is counting forested and other open portions of military bases (about 150,000 acres) much of which is used for hunting and other recreational purposes toward the goal. Both Maryland and Pennsylvania opted not to do so. But the Defense Department has raised concerns about the classification because the law requires that military lands must be available for national security purposes (Blankenship, 2001).

Maryland chose a different strategy for land preservation. Since 1969 the state has used a dedicated real-estate-transfer tax to fund "Program Open Space," which has preserved more than 230,000 acres of land. Pennsylvania has financed its land 
conservation efforts through bonds and dedicated taxes, including a real-estate-transfer tax and a cigarette tax (Virginian-Pilot, February 26, 2001). To sum up, Virginia has lagged far behind with the efforts of land preservation.

However Virginia does not look so bad if we look into statistics of overall preserved lands in the states (versus preservation under the Program initiative). Vast portions of natural areas are already protected in the three states. The jurisdictions have preserved about 6.7 million acres (Virginian-Pilot, February 26, 2001). Pennsylvania leads with 18.8 percent of its $3,538,134$ acres under protection followed by Virginia with 16.1 percent of its 2,233,048 acres preserved and Maryland with 14.7 percent of its 901,882 acres protected. But Maryland and Pennsylvania are accelerating acquisition of open space whereas Virginia is not. Maryland Governor Parris N. Glendening has proposed spending $\$ 145$ million next year for land preservation while Pennsylvania Governor Tom Ridge has proposed $\$ 140$ million (Virginian-Pilot, February 26, 2001, Chesapeake Bay Commission et al., 2001). But Virginia's refusal to be a full partner in the Chesapeake Bay's cleanup likely would complicate requests for more federal assistance (May, 2001).

The mission of protecting 20 percent of the open space in each state within the next decade could cost the states and private-sector land-preservation groups nearly $\$ 2$ billion. This seems like a lot of money, but is less than the cost of the new Woodrow Wilson Bridge; it is a relatively small price to pay for clean air and water, healthy forests, productive farms, abundant seafood and functioning ecological processes (McMahon, 2001). 
Is Growth a Local Issue?

Pennsylvania and Maryland have campaigns to manage their growth and so minimize new sources of nutrients, such as runoff from lawns and pavement. But Virginia argues that growth issues are a local not state problem. This is very a controversial issue because state aid is needed to preserve open space. Maryland and Pennsylvania are taking big strides to preserve farmland and natural areas; Virginia is not (The Virginian-Pilot, March 14, 2001). Also, Virginia should provide incentives for growth in already developed areas, rather than on a region's fringes. Maryland's smart growth program is a national leader in that regard. Incentives in Virginia work in the opposite direction. Besides providing inadequate encouragement for growth in older cities, the state also inadequately supports cities; and it resists localities' efforts to raise more revenue themselves, often resulting in declining schools and other services and comparatively high local taxes, to which more residents react by moving to suburbs. While claiming that growth is a local issue, Virginia denies its cities and counties tools that they say they need to manage growth. Lawmakers argue that localities already have, in zoning, the means to guide growth. But many high-growth cities and counties are stuck with poor decisions, years or decades back, that zoned too much land for residential development. Few localities dare to downzone. At minimum, the state needs to do more to preserve both open space and older cities. And it should at least listen to pleas from cities and counties for help in managing growth (The Virginian-Pilot, March 14, 2001). 


\section{Maryland's Achievements against Sprawl}

Maryland officials have mapped out an ecological system of land that they hope will win General Assembly approval and help sustain the forests, wetlands and streams that nourish the Chesapeake Bay watershed. Governor Parris N. Glendening proposed Green Print Program is a new land preservation effort that would provide $\$ 145$ million over five years, with a starting disbursement of $\$ 40$ million for fiscal year 2002 . The money would come from Maryland's anticipated surplus and is included in the record $\$ 1.5$ billion capital spending plan (DeFord, 2001, Professional Builder, 2001). Like Maryland's other conservation programs, Green Print depends on land purchases and development rights acquired from willing private landowners to preserve the natural landscape. The public generally supports the preservation (DeFord, 2001). One of Green Print's distinctive features is a 2 million acre network of what is called "green hubs and links" of ecologically valuable lands. The links are important in connecting the hundreds of hubs, which average 2,200 acres in size. A healthy-based ecosystem allows species to go back and forth to promote genetics and diversity. As mapped by the state's computers, Green Print's links or corridors between large land areas often travel through private farmland. If Green Print is approved, officials hope eventually to work with private owners in restoring native vegetation and natural features to those areas. Virginia and Pennsylvania need similar programs (McMahon, 2001).

According to Maryland state planners (Professional Builder, 2001), state action has preserved $20 \%$ of the Chesapeake watershed and reduced the rate of sprawl by 30 
percent. The same officials think that balancing the interests of the economy and the environment is absolutely achievable.

Though Maryland's Court of Appeals has weakened Bay protection by allowing more developments in waterfront in the past few years the state probably has the most pro environmental laws among the Bay program partners. Chesapeake Bay Critical Area Act passed in 1984, responded to the disproportionate share of development occurring around the state's tidal waterfront (Horton, 2001). Lawmakers set up a state Critical Area Commission with unique authority to set standards restricting development in the 10 percent of Maryland that lies within a thousand feet of all tidal waters. The law linked land use to water quality. Preserving the natural shoreline was the best way to filter and buffer the Bay against polluted runoff. This was one of the first times zoning had been used for wildlife protection. The law recognizes, for example, that waterfowl benefit from the solitude of undeveloped shorelines for resting, feeding and as pre-migration staging areas. The most progressive aspect of the Act was the recognition of the "cumulative impact" of Maryland's burgeoning population growth: "Even if pollution is controlled, the number, movement and activities of persons [along the water] can create adverse environmental impacts," the Act says (Horton, 2001). 


\subsection{Conclusions, Recommendations and Discussion}

The Chesapeake Bay Program is a regional partnership conducting restoration of the Bay. Chesapeake Bay Commission, a tri-state legislative body advises the three state legislatures. As it is a voluntary organization the actions are related to the free will of the participant states. The Program's strategies, plans and agreements show each state's commitment toward the restoration and do not determine which way each state has to go. This strategy gives freedom for states to work independently and concentrate on regional issues that are most urgent. On the other hand, the abstract formulation of agreements leaves room for non-compliance. For example, Virginia's state government is not spending as much money as other partner states on the restoration efforts.

Another interesting phenomenon of the Program is that even though all states are bound to the basic requirements of the Clean Water or Clean Air Acts and other federal regulations, it really depends on each state individually to determine the status of their environment. Even though all participants are trying to act as one entity, each state has its own understanding about sustainability, growth rates and priorities for land use or on what to spend money.

Recent bay restoration highlights include an analysis of 12 years of monitoring data, which shows that the major rivers and the freshwater portions of the Bay are cleaner now than they were 12 years ago ${ }^{12}$. But the 40 percent nutrient reduction goal $^{13}$ was not

\footnotetext{
${ }^{12}$ Chesapeake Bay Program, A Snapshot of Chesapeake Bay: How's it Doing? (2000) at http://www.chesapeakebay.net/pubs/snap1299.pdf

${ }^{13}$ In the 1987 Bay Agreement, the Bay Program set a $40 \%$ nutrient reduction goal to be accomplished by 2000 . In reality, though, the reduction goal is much less. Shortly after it was set, the $40 \%$ nitrogen and phosphorus goals were redefined to apply only to "controllable" sources, which substantially lowered the amount of nutrient reductions needed. The new goal equaled a $20 \%$ reduction for nitrogen and $31 \%$ reduction for phosphorus.
} 
achieved. Recently it was realized that besides conventional polluters such as wastewater treatment plants or agricultural fields there are a lot of other sources of nutrients and suspended solids that were not incorporated into the Bay model from the beginning. To mention a few: the mix of airborne nutrients from cars, trucks, boats and power plants. These pollutants contribute as much as 25 percent of all nitrogen and phosphorus in the Bay. Sprawl is one of the emerging threats and is already an issue in many places. Managers are trying to fight it, for example, using "best management practices" (BMP) ${ }^{14}$. This technique was thought to be very effective and to stem the flow of nutrients. Recently it was discovered that it works only in normal years but loses effectiveness in years with heavy rainfall (Chesapeake Bay Commission et al., 2001).

Money is often a limiting factor in the effort to achieve better results in environmental restoration. According to some state officials, the states of the Bay watershed will not be able to meet their land preservation goals without new programs and reliable sources of money (Virginian-Pilot, February 26, 2001). Many people around the nation consider Chesapeake Bay as a national treasure and there is an understanding that it should also be, in part, a national responsibility. For example, in recent years, Congress has provided $\$ 7.8$ billion, in a 20 - year program of land conservation and restoration to help save the Florida's Everglades (McMahon, 2001). There is a hope that the Federal government will also help to restore Chesapeake Bay.

Revising regulations and strategies for the Bay program is an evolving process. In the beginning it was thought that it would be sufficient just to clean up the estuary. Later

\footnotetext{
${ }^{14}$ BMP are buffer strips and other cultivation techniques used by farmers to reduce soil erosion and runoff from their fields.
} 
it was realized that we have to fight pollution and degradation of the environment while looking into the causes (pollution sources) of the water quality deterioration. Also, it was realized that local initiatives are one of the most important factors in the Bay restoration process. On the other hand, Virginia may have gone too far in giving local officials the authority to determine the future of their counties. For instance, in Virginia, overly liberal land use regulations might be the cause of losing progress in pollution control.

One of the challenges for the states will be to establish dedicated funding sources for land conservation that are not dependent on the legislature. Also, states have to develop more tax credit conservation programs, and establish more flexible local ordinances to allow local governments to better control growth (Chesapeake Bay Commission et al., 2001). Program representatives recommend establishing local taxing and bonding authority, a purchase of development rights program, public/private partnerships, and refinement of the existing conservation tax credit as viable conservation opportunities (Cat Lazaroff, February 12, 2001, Chesapeake Bay Protection Carries $\$ 1.8$ Billion Price, Environment News Service, World Reporter (TM) -Valentine Holdings Limited). Conserving farmland is a major part of the preservation effort, keeping land in productive use but out of development. The Bay Commission said that more easement funding and tax incentives are needed to meet the goal.

Recent federal studies of nine major rivers in the Bay watershed found that farming and livestock are the leading sources of water pollution, so better farming practices are needed. But the same study also stated that land-use decisions might well be the most important factor in the success or failure of efforts to restore and protect the Bay (Baltimore Sun, 2001). 
State and local governments need to embrace "green" infrastructure as a framework for conservation. Historically, most land-conservation programs have focused on the protection of individual parks, preserves or natural areas. However, to save the Bay, we need interconnected green spaces. Just as roads and other forms of "gray" infrastructure provide a framework for growth, green infrastructure can be a framework for conservation. Also state and local governments must finance and manage green infrastructure as a primary public investment. Roads and other forms of gray infrastructure are financed through dedicated gas taxes and other stable mechanisms. Likewise, there is a need for dedicated sources of revenue for green-space protection. Elected officials must recognize that preserving green space not only can help save the Bay but also can help alleviate growing opposition to development. When people think that all land is up for grabs, they oppose development everywhere. When they have some assurance that special places will be preserved, they are less likely to fight development. Finally, we need to recognize that land protection does not necessarily mean public ownership of the land. Most land now being preserved throughout the watershed remains in private hands subject to conservation easements ${ }^{15}$. Furthermore, preserved green space adds value to adjacent development (The San Isabel Foundation, 2001).

It might seem that the rights of the landowners and developers are overlooked in new environmental laws and regulations. Property owners are complaining that their owner rights are violated or that the rules do not consider the cost that the regulation is

\footnotetext{
${ }^{15}$ Conservation easements- a binding legal agreement, which prevents future development and perpetually restricts the use of land to activities that do not degrade its resources. The property stays in private ownership and can be sold, leased, mortgaged or bequeathed without compromising the restrictions. Landowners who donate conservation easements may be eligible for income and estate tax savings. This method is currently in use in the Chesapeake Bay Program (at http://www.sanisabel.org/whatisa.htm)
} 
imposing to their activities. To those complaints it can be said that few decades ago it was just the opposite: the environment could be degraded and no one had to take responsibility for that. In the short term, unplanned and unregulated growth and development bring big revenues, but in the long run the costs exceed the benefits.

There are some good examples of how mutually beneficial results can be achieved: Celebrate Virginia! is a 1400-acre proposed development in Stafford County, Virginia, consisting of a campus-style office park, commercial and retail areas, and three golf courses. It is a small watershed known as England Run. The potential impacts to wetlands areas include nearly 10 acres, and almost 32,000 linear feet of U.S. waters could be impacted. To address this concern, EPA and the Army Corps of Engineers are working with the developer to implement a low-impact design and a highly distributed storm water management program. Detailed runoff models will be used to predict the runoff from different development scenarios. In addition, the developer has agreed to mitigate for the unavoidable impacts through a variety of measures scattered throughout the watershed, including storm water retrofits for already developed portions of the watershed (EPA region 3 Enviro-Bites, 2001).

It is true that to deal with environmental issues is a costly "business" but for those who say we cannot afford $\$ 2$ billion for land preservation despite the evidence of a seriously troubled Chesapeake Bay, Oscar Wilde once stated " a cynic is a man who knows the cost of everything and the value of nothing" (McMahon, 2001).

Law -making plays a key role in supporting the efforts to promote growth while protecting the environment in the Bay region. The Program has been a success in some areas (e.g. phosphorus reduction) and in some states (e.g. Maryland's Chesapeake Bay 
Critical Area Management Act) and failed in the other issues (e.g. nitrogen run off) and states (e.g., Virginia's strategy regarding cities planning). Current Bay Program legislature has to be carefully evaluated and amended in regard to the efforts to reduce degradation of the environment. The law should be improved in addressing sprawl, population growth, and pollution control issues. Unless it catches up with the rapid degradation of the ecosystems, the exponential negative impacts of growth may prove irreversible. Existing strategies, acts and regulations seem to have a positive impact on the environmental protection, however, as conveyed in this paper, environmental law still has a long way to go. 


\section{ENVIRONMENTAL INDICATORS}

\subsection{Introduction}

The Town of Cape Charles (Figure 3-1) is located along the western coast of Virginia's Eastern Shore peninsula and consists of nearly 2,500 acres of land fronting Chesapeake Bay and its tributaries. A large portion of the town was recently annexed in anticipation of the Bay Creek Development, a recreation based retirement community. The proposed Bay Creek Development ${ }^{16}$ surrounds the currently developed areas of the town. The master plan for this development includes approximately 3,000 residential units, a recreation center and marina, and limited commercial development including shops and hotel. Two eighteen-hole signature golf courses will be constructed as a key feature of the project. The entire area of the Bay Creek Development is approximately 1,730 acres with the majority of the development taking place to the south of the currently developed areas of the town. All of the golf course area and commercial development are included in this South Tract. The North Tract consists of residential development and a marina complex.

\footnotetext{
${ }^{16}$ Explanations of the terms used in the text and pictures are given in the Glossary (APPENDIX)
} 
Land use determines nutrients and sediments loads, which in turn determines water quality. In this study the relationship between land use and water quality was investigated using BasinSim and Tidal Prism Water Quality (TPWQM) models. The models provided information about water quality change under different development scenarios. According to the habitat suitability indexes (as described in the Literature Review) it was possible to assess the impacts and consequences of land use change. Submerged aquatic vegetation (SAV) was chosen as indicator species. SAV habitat requirements were chosen as indicators also because of data availability.

Old Plantation Creek (the creek) was investigated as one of the sensitive areas, that may be affected by development. This creek is approximately $5 \mathrm{~km}$ long. It was expected that water quality would be different in different parts of the creek (Figure 3-1), taking into consideration different land use patterns along the water body, influence of the tides, bathymetry and geometry. For that reason the creek was divided into three segments to better represent expected variability. Segmentation of the creek was performed using the TPWQM "Pre-Processor of Geometry". In order to determine nutrient and suspended solid loads to the creek, BasinSim model was used. At the end, the TPWQM was used in order to predict pollutant concentrations in the water column in different parts of the creek.

\subsection{Methods}

Segmentation of the Area

Old Plantation Creek is a geometrically diverse system (Figure 3-2.). The mouth of the creek is wide (500 meters) but there is a distinguishable channel and numerous 
small islands, tidal flats, shallows and small wetlands. The middle part of the creek has some relatively deep areas (three meters) and a wide channel. The upper part of the creek is shallow ( 0.3 meter) and narrow (approximately 200 meters). We expected that water quality in different parts of the creek would be different. The watershed draining to the creek is also diverse. For these reasons the creek and watershed was divided into segments in order to get a gradient of nutrients and chlorophyll "a" concentrations in different parts of the creek, and nutrients and sediments loads from the watershed. In other words the segmentation enabled us to assess the pollutant loads from different parts of the watershed and pollutant concentrations in different parts of the creek.

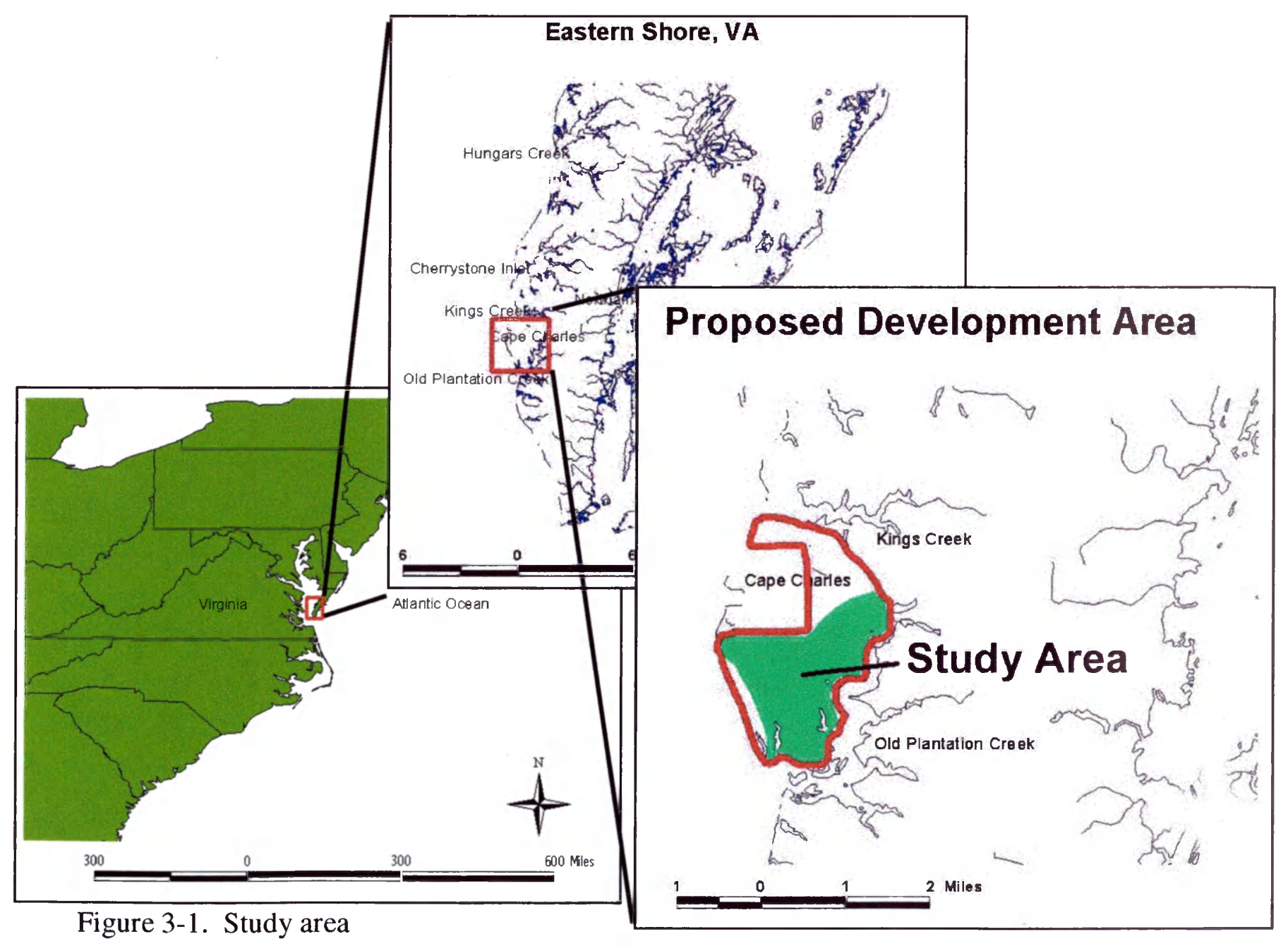


The creek has several tributaries, which are mainly tidal flats during the ebb tide. For this reason and because the tributaries are located on the other side of the Proposed Bay Creek Development, the creek was investigated as one entity.

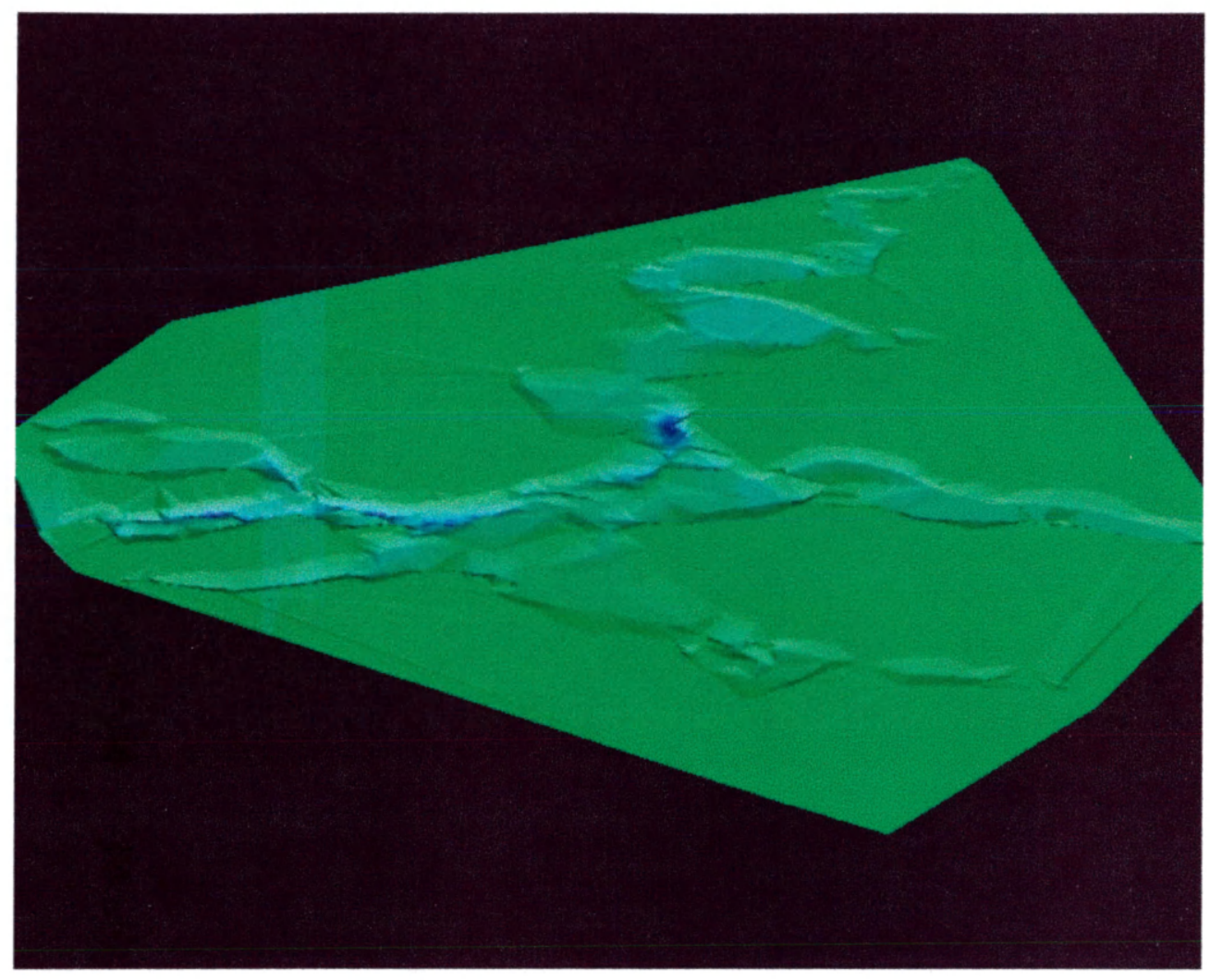

Figure 3-2. Old Plantation Creek bathymetry map (source: USGS, at http://edc.usgs.gov/glis/hyper/guide/1_dgr_demfig/states.html)

\section{Segmentation Technique (Pre Processor for Geometry)}

'Pre Processor for Geometry' of the TPWQM was used to divide the creek into segments that reflect the bathymetry of the stream. The expert system performed automatic segmentation of the creek basin based on given geometric information. The creek is small enough that a uniform value for tidal range for the entire system could be used. Geometric data for the channel are presented in the Table 3-1. The output file for 
Creek segmentation is presented in Table 3-2. The output file contains the segmentation information including high water volume, tidal prism and mean water depth for each segment; linear interpolation was employed to generate the geometric information between the specified locations (Kuo \& Park, 1994).

One output file/segmentation scenario was used repeatedly for different development scenarios. Fig. 3-3 show the segmentation of the creek. (The full description of the division technique/process can be found in the TPWQM manual (KuO et al., 1999))

Table 3-1. Segmentation of the Old Plantation Creek, Input file

\begin{tabular}{|c|c|c|c|}
\hline \multicolumn{2}{|c|}{$\begin{array}{l}\text { Tidal range - } \\
2.4 \text { feet }\end{array}$} & $\begin{array}{c}\text { Channel length - } \\
3.37 \text { miles }\end{array}$ & $\begin{array}{c}\text { Number of segment } \\
8 \\
\end{array}$ \\
\hline $\begin{array}{l}\text { Segment } \\
\text { number }\end{array}$ & $\begin{array}{l}\text { Distance from } \\
\text { the mouth, feet }\end{array}$ & $\begin{array}{l}\text { Depth of the } \\
\text { segment, feet }\end{array}$ & $\begin{array}{l}\text { Channel width, } \\
\text { feet }\end{array}$ \\
\hline 1. & 0 & 2 & 1,600 \\
\hline 2. & 2,379 & 1 & 1,400 \\
\hline 3. & 4,508 & 1 & 1,500 \\
\hline 4. & 6,890 & 3 & 1,700 \\
\hline 5. & 9,236 & 2 & 1,200 \\
\hline 6. & 12,204 & 1 & 900 \\
\hline 7. & 13,993 & 1 & 600 \\
\hline 8. & 17,008 & 1 & 500 \\
\hline
\end{tabular}


Table 3-2. Segmentation of the Old Plantation Creek, Output file

\begin{tabular}{|c|c|c|c|c|}
\hline \multicolumn{5}{|c|}{$\begin{array}{l}\text { Modified: } 20010127 \\
\text { Hydrodynamic \& Geometry Input }\end{array}$} \\
\hline $\begin{array}{l}4 \\
0\end{array}$ & $\begin{array}{l}0 \text { OPC } \\
\text { Number }\end{array}$ & of storages & & \\
\hline \multicolumn{5}{|c|}{$\$ \$ \$$ Geometry and hydrodynamic input $\$ \$ \$ *$} \\
\hline $\mathrm{CH}$ & $\begin{array}{ll}\text { S\# } & \text { DIST } \\
& (\mathrm{km})\end{array}$ & $\begin{array}{l}\mathrm{VH} \\
\left(10^{\wedge} 6 \mathrm{~m}^{\wedge} 3\right)\end{array}$ & AL & $\begin{array}{l}\mathrm{HA} \\
(\mathrm{m})\end{array}$ \\
\hline M 0 & 10.000 & $0.000 \quad 1.933$ & 0.300 & 0.000 \\
\hline M 0 & 2.960 & 1.9360 .877 & 0.300 & 0.975 \\
\hline M 0 & 4.300 & 0.8760 .399 & 0.300 & 0.975 \\
\hline M 0 & 45.420 & 0.7320 .000 & 0.300 & 0.975 \\
\hline
\end{tabular}

* - OPC - Old Plantation Creek CH 0 -Main Channel S\# - Segment number DIST - Distance in kilometers $\mathrm{VH}$ - High tide volume in the segment

P - Tidal prism upstream of the segment

$\mathrm{AL}$ - Returning ratio HA - Water depth

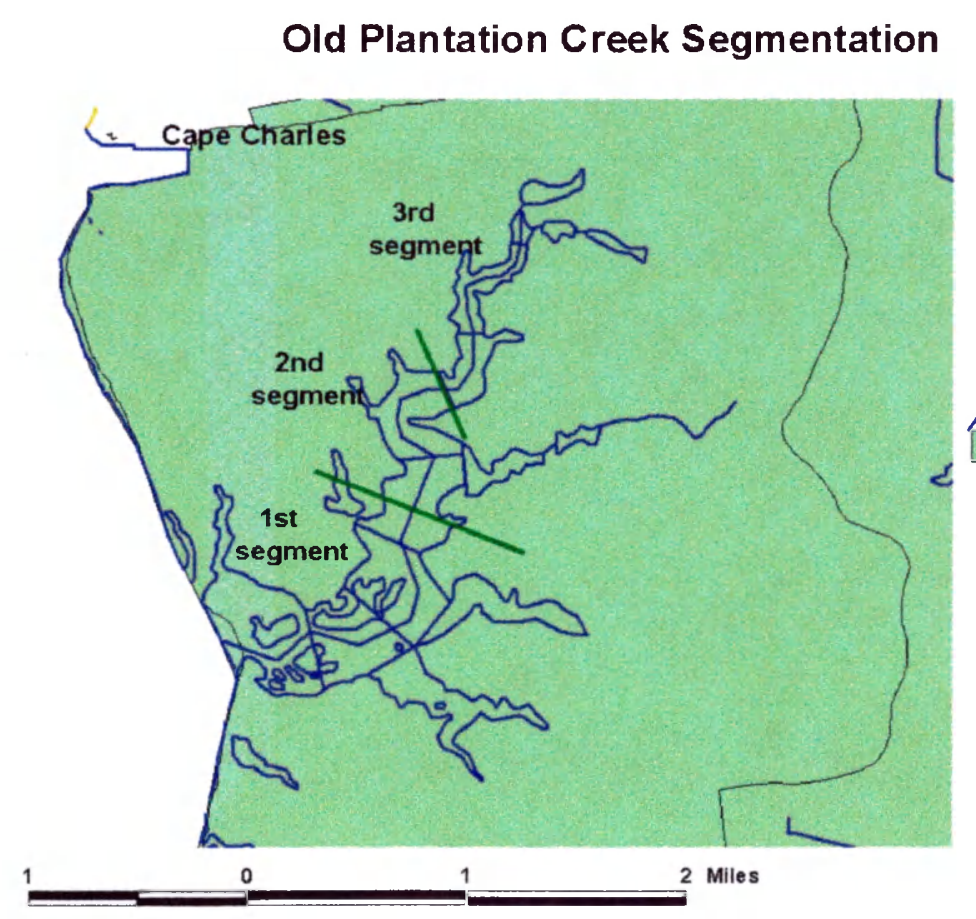

Figure 3-3. Old Plantation Creek segmentation according to the TPWQM Pre-Processor of Geometry. Two green lines show the division $\checkmark$ ofithe.shek into three slyghertests Bline lines across the creek show the Pre Processor of Geometry input file information. The line in the middle of the creek shows the channel location and according to the line the length of the cre $\mathrm{k}$ was calculated.

Calibration of the creek segmentation was performed using the bathymetric map (Figure 3-2) of Old Plantation Creek with the help of Arc View 3D Analyst. The input 
file for the TPWQM accepts only 15 points regarding bathymetry of the water body. Water volume for the creek may be exaggerated, since topographic maps most likely show the maximum depth of the main channel. The volume of the creek according to the calculations in Arc View is 3.5 million cubic meters. The initial segmentation input file was changed to reflect this volume number and according to the corrected results the volume is 3.5 million cubic meters. (The first estimate of the volume of the creek was 5 millions cubic meters).

According to the segmentation presented above, the creek watershed was divided into smaller segments/watersheds. Segmentation of the creek watershed is presented in Figure 4. In the same figure the land use/land cover is presented. Fig. 3-5 presents the first segment of Baseline scenario. Data from two different maps were used to segment the watershed: a) elevation maps of the area (map source: Land Use/Hydrogeology GIS Database, Eastern Shore of Virginia, by Malcolm Pirnie: Environmental Engineers, Scientists and Planners); and b) "Existing Drainage Divides” by Espey, Huston \& Associates, Inc. in the study Baseline Environmental and Technical Reference Document for The Proposed Accowmacke Plantation Development Northampton County, Virginia, 1990. 


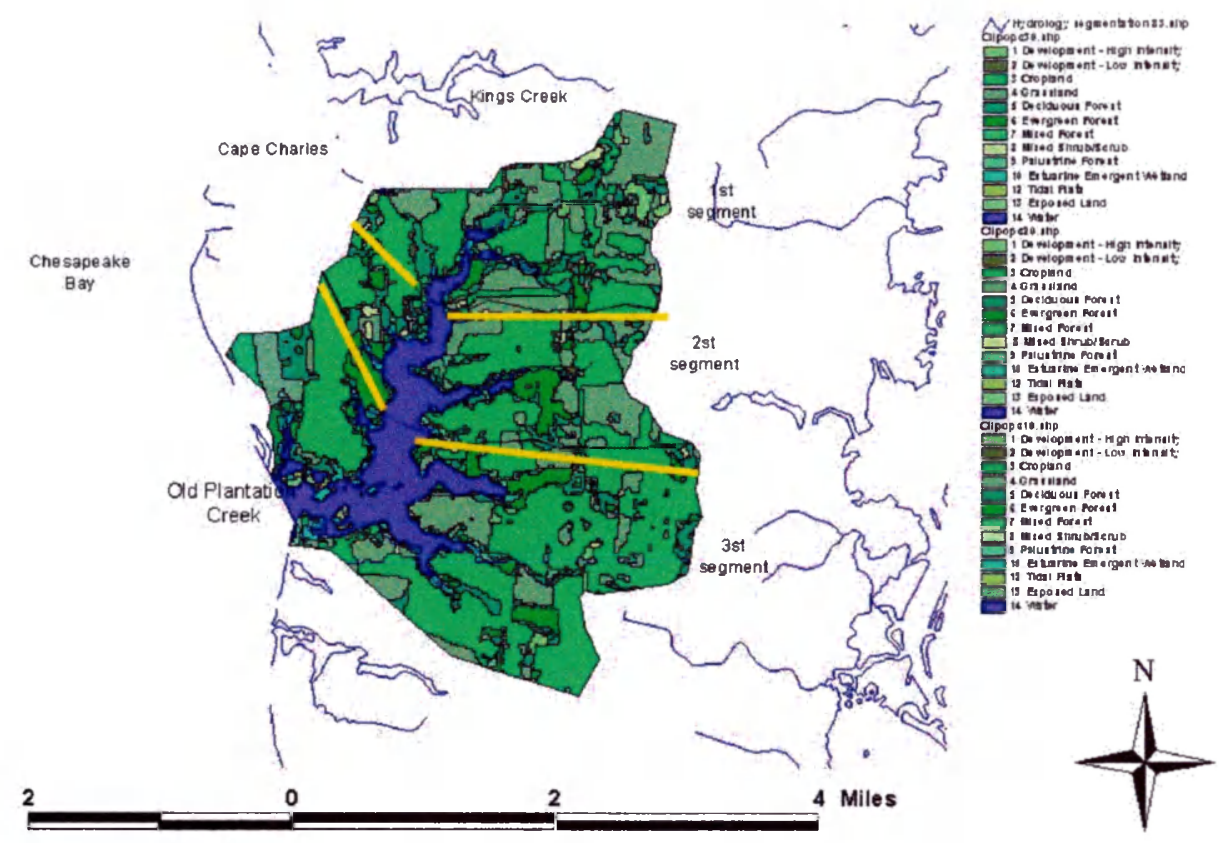

Figure 3-4. Old plantation Creek watershed land use and division into segments

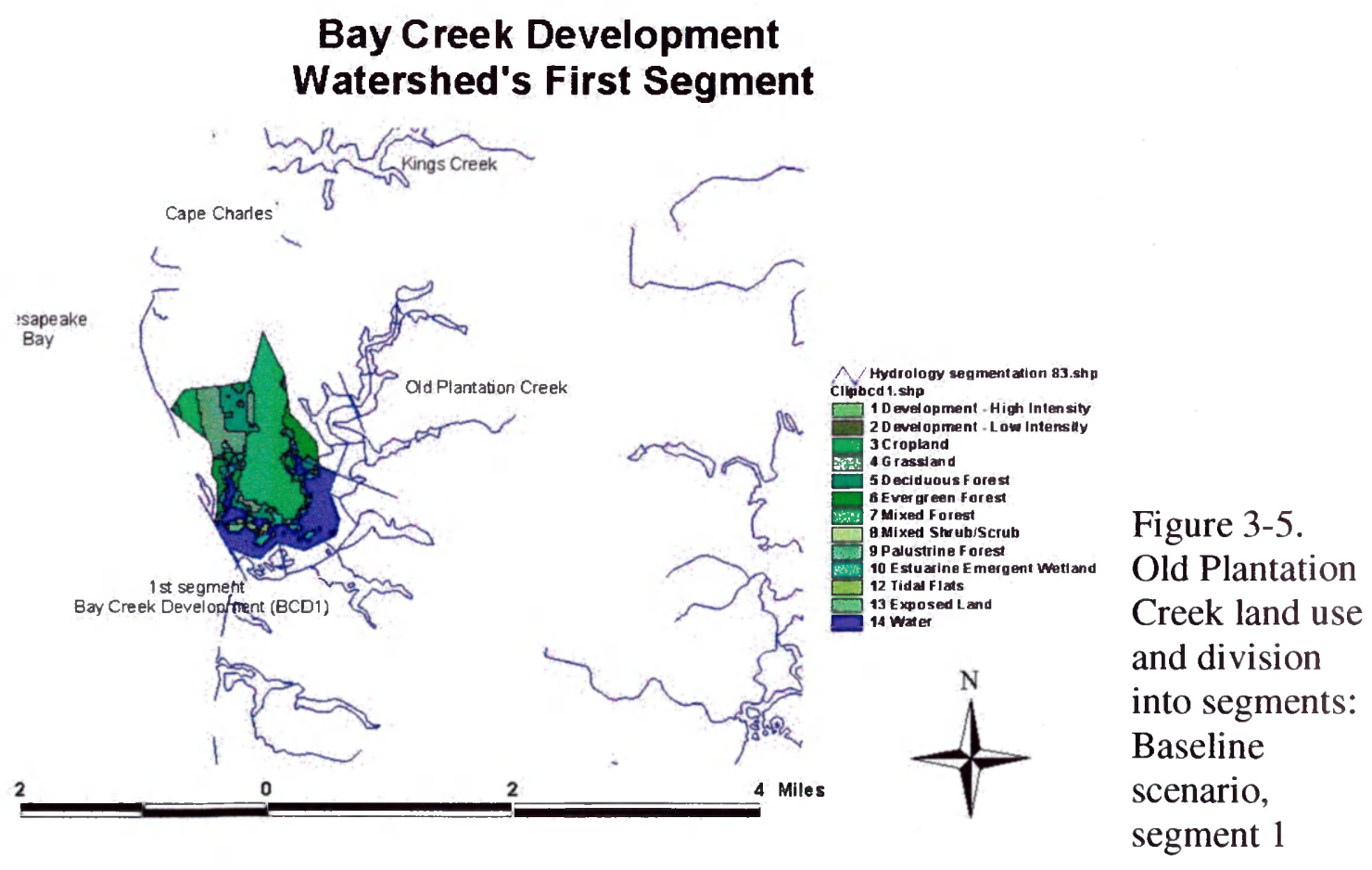


In Figure 3-6 the Bay Creek Development plan is presented.

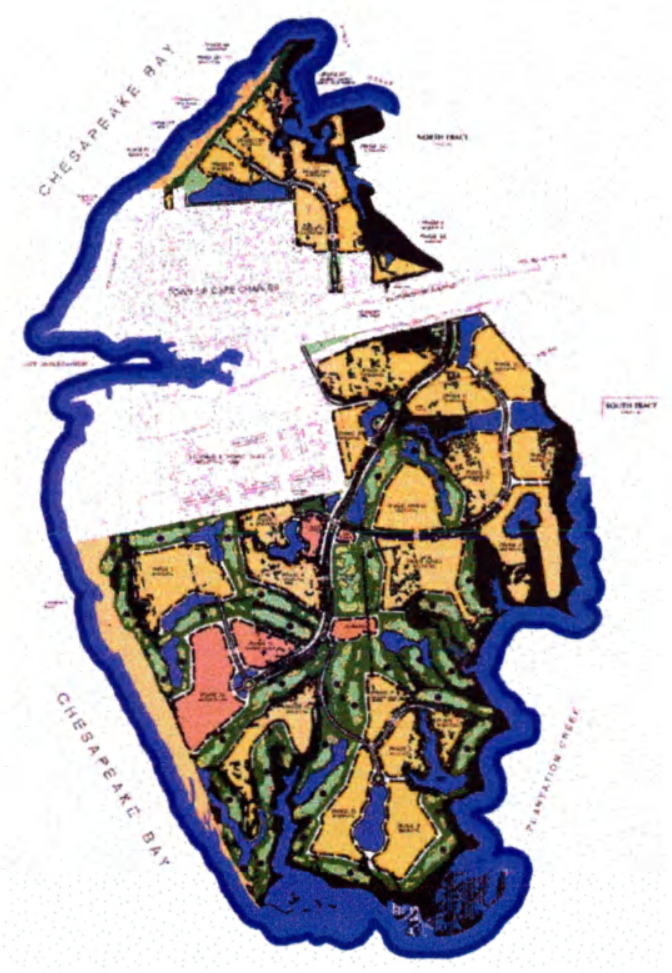

Figure 3-6. Proposed Bay Creek Golf

Course/Residential Area Plan

Yellow areas represent residential area,

light greens show golf course location, darker greens - forest.

\section{Scenarios}

The Cape Charles area was chosen as a model region for the analysis of different development scenarios. The study area was determined according to proposed development (Bay Creek Development). Natural conditions (watershed, topography) were taken into consideration while determining the boundaries of the watershed. Some runoff from the study watershed is draining directly to the Chesapeake Bay and not into the creek: those parcels of land were not taken into consideration (see Fig. 3-4). 
Scenarios are presented bellow:

1. Baseline scenario - year 1989 (based on Proposed Bay Creek Development watershed, part of the Old Plantation Creek watershed) (Figures 3-4, 3-5)

2. Agriculture scenario

3. Forest scenario

\section{Golf Course scenario (Proposed Bay Creek Development)}

As the main activity on the Eastern Shore is agriculture, the Agriculture scenario was created with the assumption that the Baseline scenario is converted to 100 percent agricultural land, seeking to increase benefits from the land. Forest scenario was created on the assumption that forest is the most pristine land use and contributes the least amounts of pollutants to adjacent creeks. The Golf Course scenario is based on the development plan of the Bay Creek Development. In order to get a picture of total pollutant loads and water quality in the creek, the "Whole" watershed sub-scenario was created (see Fig. 3-4). Baseline scenario watershed (546 ha) is at least four times smaller than the creek watershed ("Whole" watershed sub-scenario (2,290 ha)). Different scenarios were created changing land use percentages in each case. Relative land use areas in each scenario are presented in Figures from 3-7 to 3-12.

In 1989 less than one third of the Baseline scenario area was forest and the rest agricultural land with some inclusion of wetlands and residential areas (Figure 3-7, Table 12). Almost the same land use scenario was observed in the whole Old Plantation Creek watershed at the same time (Figure 3-11). In the case of the Agriculture scenario it was assumed that almost all land use (except wetlands and residential area) was converted to agricultural land (Figure 3-8, Table 12). The Forest scenario was created to study the 
differences between background and anthropogenic effects on nutrient and sediment loadings. The Forest scenario (Figure 3-9, Table 12) represents the same land uses as in Baseline scenario except that all agricultural land was assumed to be converted to forest. The Golf Course scenario (Figure 3-10, Table 11) was created to study the effects of the development on the surrounding environment. The plan for the development was taken from the Bay Creek development web site. The developers refused to collaborate in this study so the relative land use areas were calculated from Figure 3-6. The map was scanned to get relative values for each land use. ERDAS Imagine software was used, and relative percentage of each land use was determined. In the Golf Course scenario forest comprised $\sim 30 \%$, residential $\sim 40 \%$, golf course/grass $25 \%$ of land use (tidal flats, wetlands remained unchanged). 


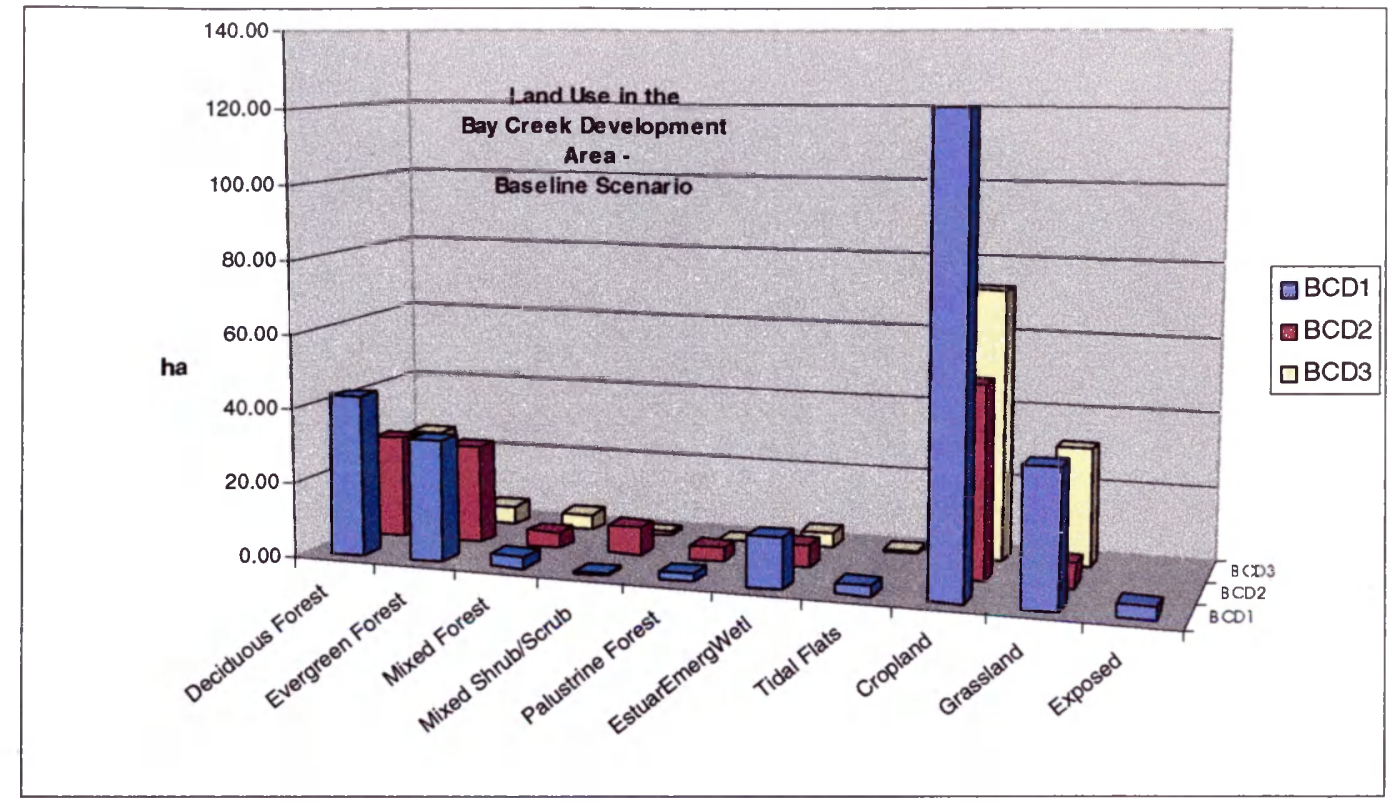

Figure 3-7. Land use - Baseline scenario

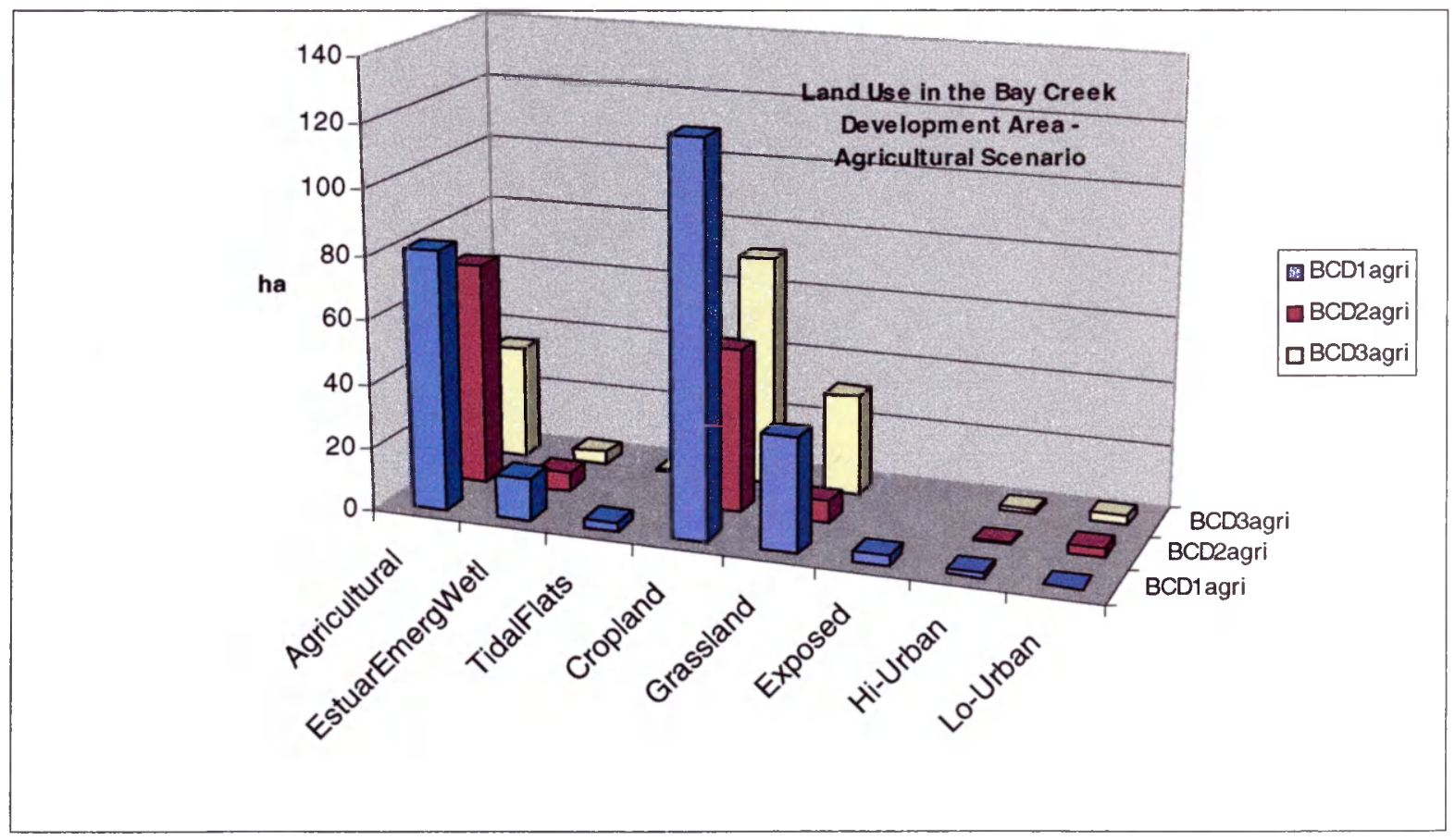

Figure 3-8. Land use - Agriculture scenario 


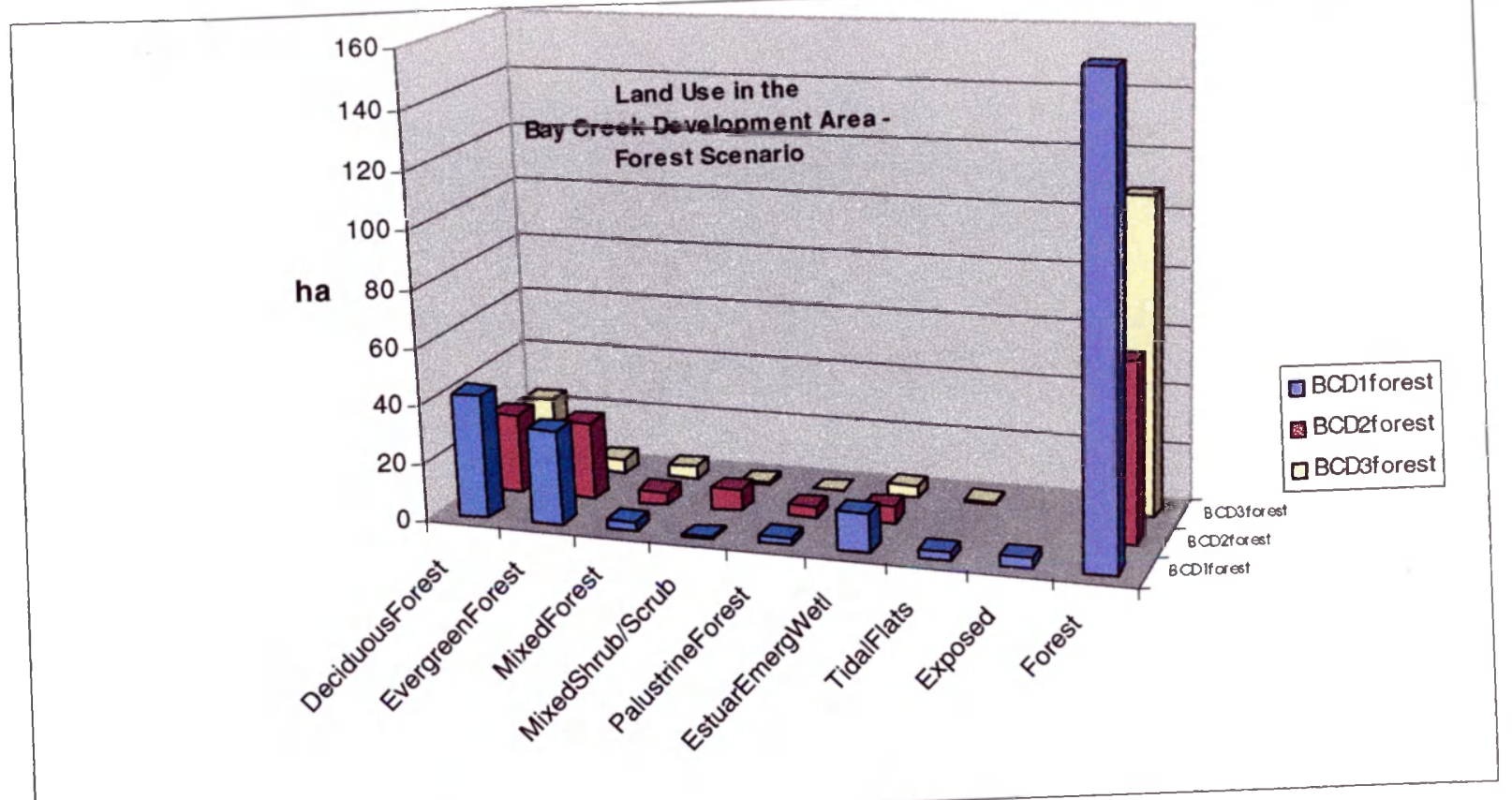

Figure 3-9. Land use - Forest scenario

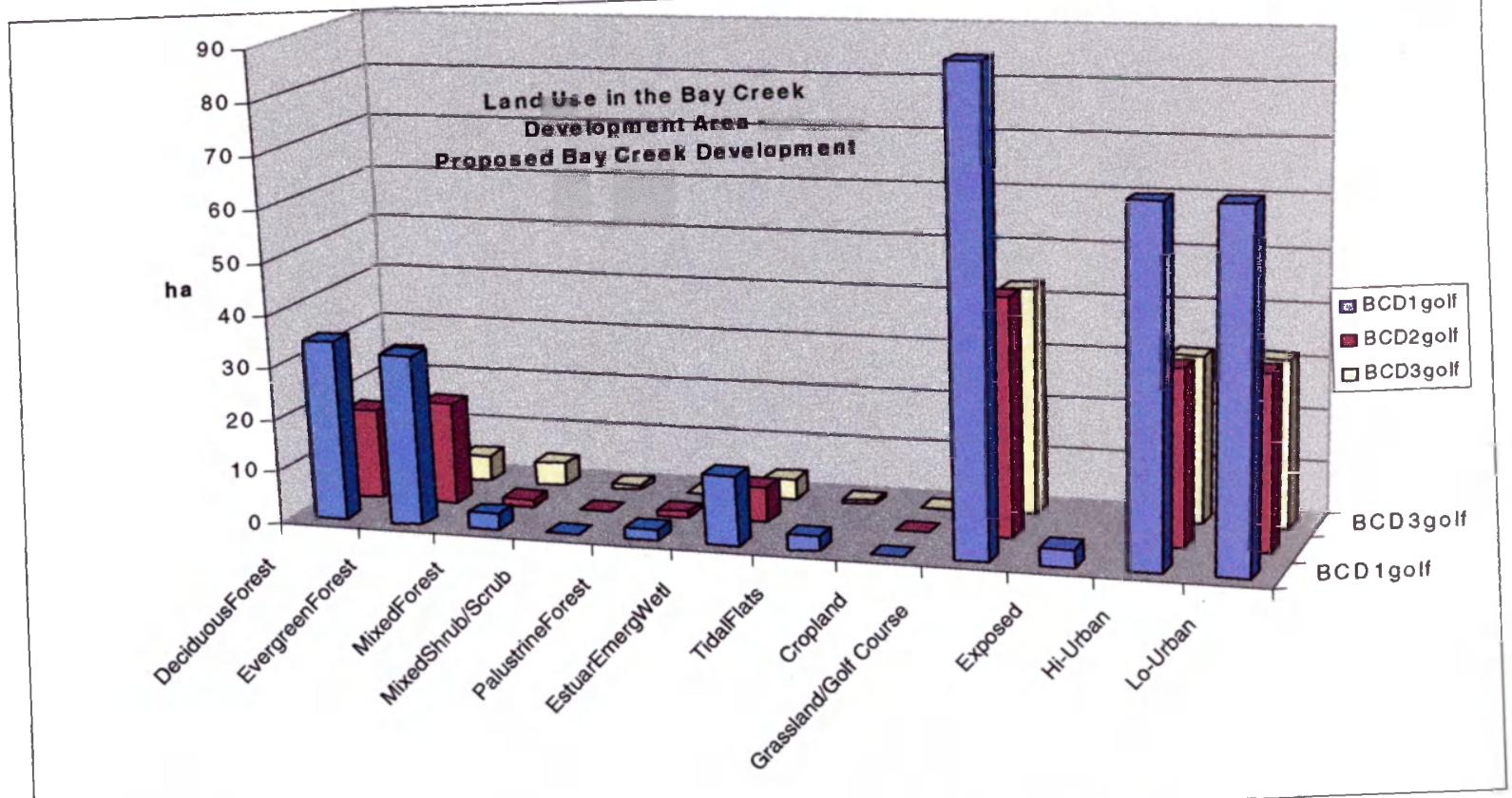

Figure 3-10. Land use - Golf Course scenario 


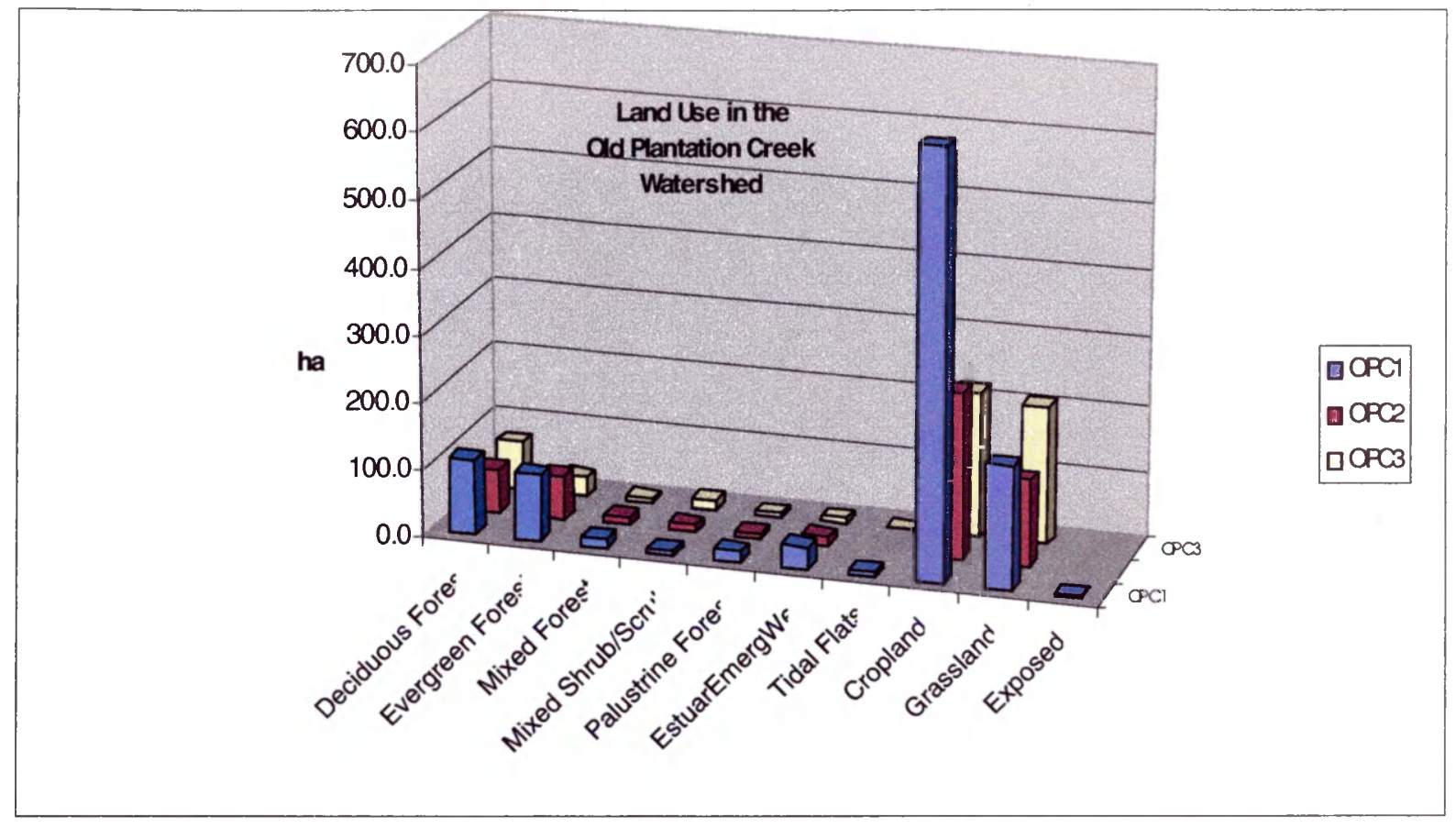

Figure 3-11. Land use - Whole watershed, Old Plantation Creek

Table 3-3. Land use in 4 scenarios: summary

\begin{tabular}{|c|c|c|c|c|c|c|c|c|c|c|}
\hline Scenario & $\begin{array}{l}\text { Baseline } \\
\text { (ha) }\end{array}$ & $\%$ & $\begin{array}{l}\text { Agri } \\
\text { (ha) }\end{array}$ & $\%$ & $\begin{array}{l}\text { Forest } \\
\text { (ha) }\end{array}$ & $\%$ & $\begin{array}{l}\text { Golf } \\
\text { (ha) }\end{array}$ & $\%$ & $\begin{array}{l}\text { Opc } \\
\text { (ha) }\end{array}$ & $\%$ \\
\hline Deciduous Forest & 96 & 18 & 0 & 0 & 425 & 78 & 77 & 14 & 251 & 11 \\
\hline Evergreen Forest & 65 & 12 & 0 & 0 & 65 & 12 & 57 & 10 & 192 & 8 \\
\hline Mixed Forest & 12 & 2 & 0 & 0 & 12 & 2 & 9 & 2 & 31 & 1 \\
\hline Shrub/Scrub & 9 & 2 & 0 & 0 & 9 & 2 & 1 & 0 & 33 & 1 \\
\hline Palustrine Forest & 6 & 1 & 0 & 0 & 6 & 1 & 3 & 1 & 30 & 1 \\
\hline Estuarine Emergent Wetland & 23 & 4 & 23 & 4 & 23 & 4 & 23 & 4 & 55 & 2 \\
\hline Tidal Flats & 4 & 1 & 4 & 1 & 4 & 1 & 4 & 1 & 7 & 0 \\
\hline Cropland & 245 & 45 & 432 & 79 & 0 & 0 & 0 & 0 & 1100 & 48 \\
\hline Grassland & 74 & 14 & 74 & 14 & 0 & 0 & 177 & 32 & 519 & 23 \\
\hline Exposed & 3 & 1 & 3 & 1 & 3 & 1 & 3 & 1 & 5 & 0 \\
\hline Hi-Urban & 4 & 1 & 4 & 1 & 0 & 0 & 95 & 17 & 49 & 2 \\
\hline Lo-Urban & 6 & 1 & 6 & 1 & 0 & 0 & 95 & 17 & 17 & 1 \\
\hline total & 546 & 100 & 546 & 100 & 546 & 100 & 546 & 100 & 2290 & 100 \\
\hline
\end{tabular}


Spatial Data Sources, Format

For the Model preparation and analysis GIS data of the area were obtained from these sources:

Land cover/Land use - Coast Watch Change Analysis Program (C-CAP) Land Cover and Land Cover Change Data, Chesapeake Bay, 1992. The data were obtained in the Imagine ERDAS file format and was converted into Arc View/Info shape file;

Soils - U.S. Department of Agriculture, Natural Resources Conservation Service (Natural Resources Conservation Service. 2000);

Hydrology - The Center for Coastal Resources Management, Virginia Institute of Marine Science.

All spatial data obtained from different sources with different data formats were converted into the following format:

Grid_Coordinate_System_Name: Universal Transverse Mercator

UTM_Zone_Number: 18

Planar_Distance_Units: meters

Horizontal_Datum_Name: North American Datum of 1983

Spatial data analysis (display, overlay of layers, areas calculation) was performed with the help of Arc View Software's Spatial Analyst and 3D Analyst.

\section{BasinSim Model description and data files}

Several models exist for assessing nutrient loads from watersheds. Some of the models such as the Hydrologic Simulation Program-FORTRAN (HSPF) and the General Ecosystem Model require large amount of data, which are not readily available. Simple 
models such as empirical export-coefficient models require small data sets but the accuracy is poor (Dai et al., 2000). According to Dai et al. (2000) the BasinSim model "is a compromise between the empiricism of export-coefficient methods and the complexity of detailed mechanistic models".

BasinSim 1.0 modeling software simulates the small watersheds systems processes that predict sediment and nutrient loads. The simulation system is based on the Generalized Watershed Loading Functions (GWLF) (Dai et al., 2000). In BasinSim 1.0, the GWLF model simulates the hydrologic cycle in a watershed and predicts stream flow based on precipitation, evapotranspiration, land uses and soil characteristics. The general structure of the GWLF model is shown in Figure 3-12.

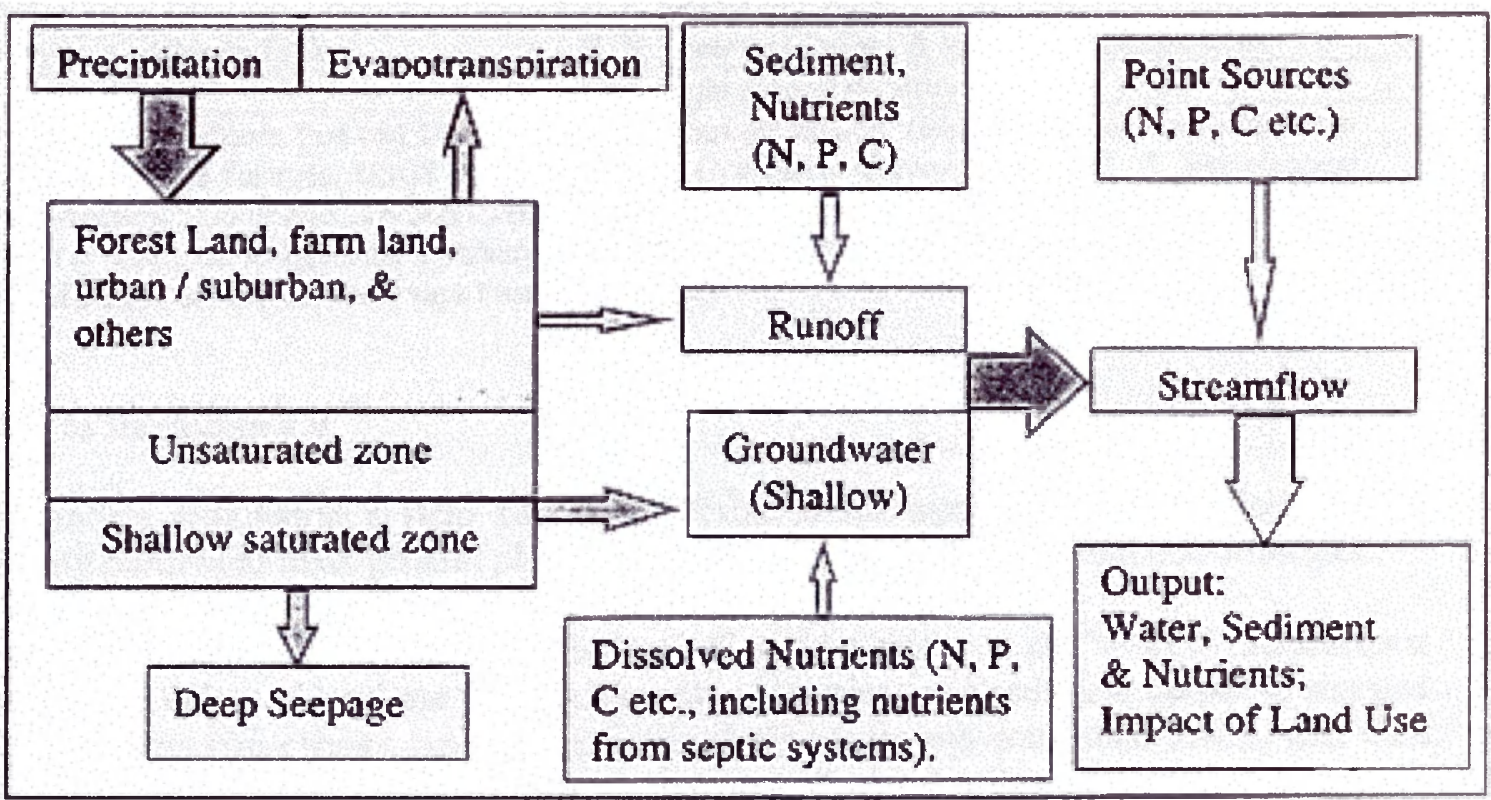

Figure 3-12. Structure of the GWLF model

Shaded arrows indicate the hydrologic cycle (Taken from Dai et al, 2000)

The GWLF model includes dissolved and solid-phase nitrogen and phosphorus in stream flow from the sources shown in figure below: 


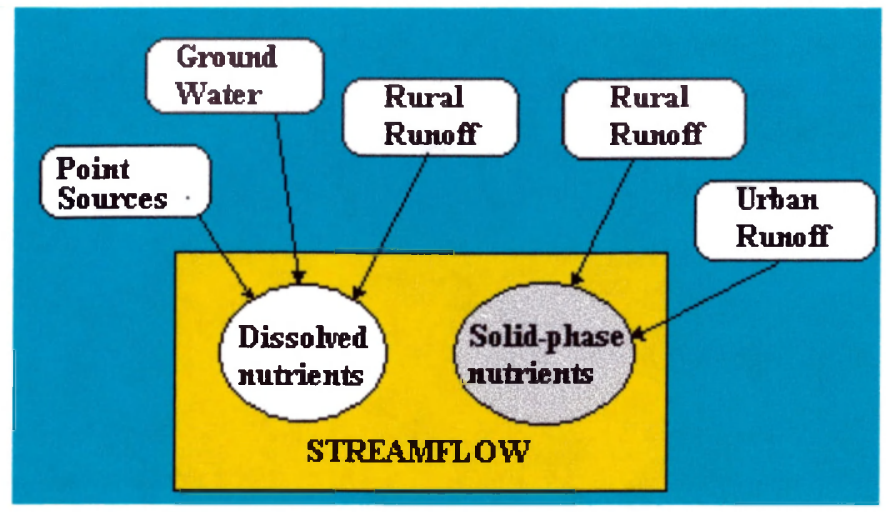

Figure 3-13. Nutrient Sources in GWLF

Rural nutrient loads are transported in runoff water and eroded soil from numerous source areas, each of which is considered uniform with respect to soil and cover. Dissolved loads from each source area were obtained by multiplying runoff by dissolved concentrations. Runoff is computed by using the Soil Conservation Service Curve Number Equation. The product of monthly sediment yield and average sediment nutrient concentrations determines solid-phase rural nutrient loads. Erosion is computed using the Universal Soil Loss Equation and the sediment yield is the product of erosion and sediment delivery ratio. The yield in any month is proportional to the total transport capacity of daily runoff during the month. Urban nutrient loads, assumed to be entirely solid-phase, are modeled by exponential accumulation and wash off functions. The product of a cover factor and potential evapotranspiration defines daily evapotranspiration. The latter is estimated as a function of daylight hours, saturated water vapor pressure and daily temperature (Dai et al., 2000).

Stream flow consists of runoff and discharge from groundwater. The latter is obtained from a lumped parameter watershed water balance. Daily water balances are calculated for unsaturated and shallow saturated zones. Infiltration to the unsaturated and shallow saturated zones equals the excess, if any, of rainfall and snowmelt less runoff and 
evapotranspiration. Percolation occurs when unsaturated zone water exceeds field capacity. The shallow saturated zone is modeled as a linear groundwater reservoir (Dai et al., 2000)

\section{Input files (BasinSim)}

BasinSim requires three input files: weather, transport and nutrients. Transport and nutrient input data files were created for each land use scenario and for each watershed segment, while only one weather file was used for all scenarios and watershed segments. (For the description of the changes made to different files for different scenarios see Tables from 3-4 to 3-6).

\section{Weather File and Data}

The weather file is comprised of temperature and precipitation data. Weather data for the research area were obtained from four University of Virginia stations in the Eastern Shore Reserve. These stations are located on the ocean side of the Eastern Shore, approximately 5-10 miles away from the research area. Seven years of data were used for the project: March 1, 1989 to April 30, 1996. Temperature is recorded in degrees Celsius and precipitation in centimeters. The weather data are presented in Figures 3-14 and 3-15. Data from the four stations were averaged in order to get a better representation of the weather in the region. 


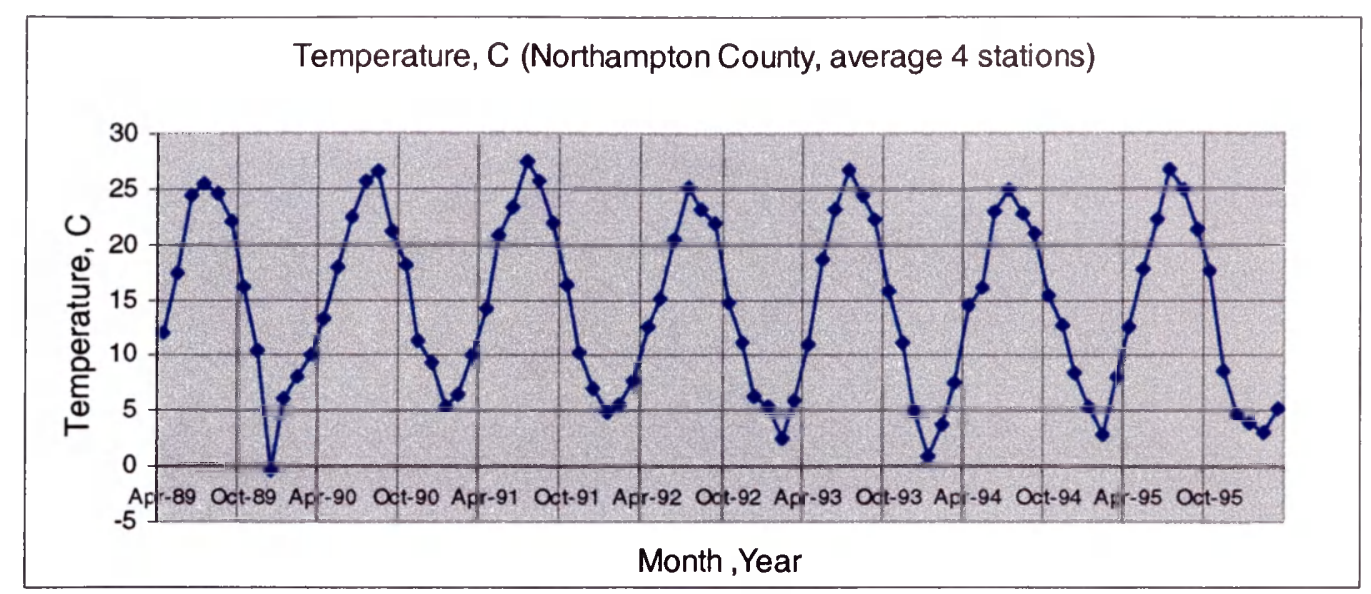

Figure 3-14. Monthly temperatures $\left({ }^{\circ} \mathrm{C}\right)$ for the Eastern Shore

(Krovetz et al., 1996)

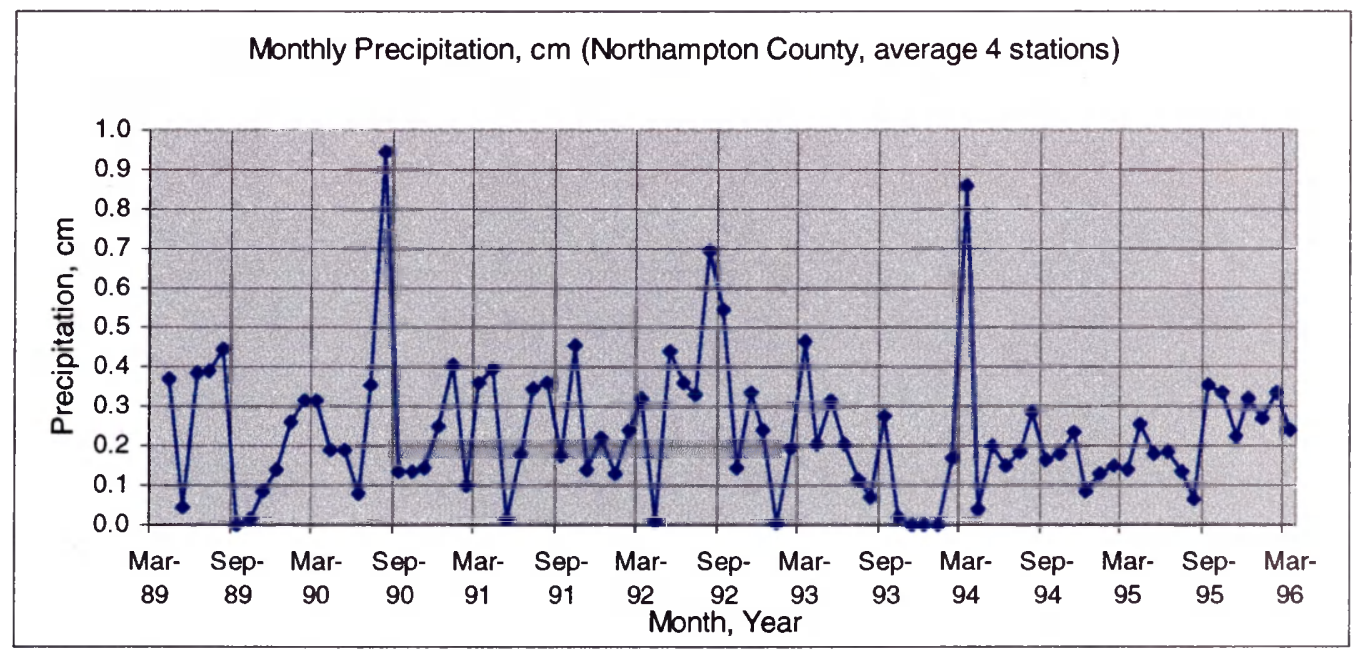

Figure 3-15. Monthly daily precipitation (cm) for the Eastern Shore

(Krovetz et al., 1996).

For the purpose of model calibration and validation monthly freshwater flow data were obtained. The station is located on Guy Creek near Nassawadox, VA. 


\section{Transport Data}

The transport file includes the following parameters: recession coefficient, seepage coefficient, initial unsaturated storage, initial saturated storage, initial snow, sediment delivery ratio and unsaturated zone available water capacity, precipitation values $(\mathrm{cm})$ for the five days preceding the start of the simulation. Monthly parameters include: evapotranspiration cover coefficient, day hours, growing season flag and erosivity coefficient, land types, area in hectares, soil curve \# and KLSCP.

The recession coefficient value of 0.04 was chosen for all transport files. Regarding the four following parameters, the values chosen were default for the region (Virginia): seepage coefficient: 0; initial unsaturated storage: $10 \mathrm{~cm}$; initial saturated storage: $0 \mathrm{~cm}$; initial snow (melt): $0 \mathrm{~cm}$. Sediment delivery ratio (required in the transport file for the calculation of sediment output) was determined according to the research area. Unsaturated zone available water capacity was chosen default: $10 \mathrm{~cm}$. The next five lines of the transport file list precipitation values $(\mathrm{cm})$ for the five days preceding the start of the simulation and they were chosen to be 0 .

The evapotranspiration cover coefficient (ET), growing season flag (is there vegetation or not) and erosivity coefficient varied according to the land use and land cover and according to the growing season of the plants. Day hours were determined according to latitude. The final portion of the transport file lists land types, area in hectares, soil curve number and erosion product $\mathrm{K} * \mathrm{LS} * \mathrm{C} * \mathrm{P}$ for each runoff source. 


\section{Evapotranspiration Cover Coefficient}

The ET cover coefficient is the ratio of water loss by evapotranspiration from ground and plants compared to what would be lost by evaporation from an equal area of standing water (GWLF, 1996). ET cover coefficient varies by land use type and time period within the growing season. The value is usually between 0 (impervious surfaces) and 1 (e.g. water). The numbers entered into the transport file are monthly averages calculated for the entire watershed, weighted by land use percentages.

\section{Soil Curve Number}

Soil Curve Number was determined by using GIS software overlaying the land use map with the soil map. Then areas were calculated for each soil type within each land use (using Arc View Spatial Analyst's Tabulate Area function). The hydrologic group used for the soil curve number was the group expressing the highest percentage within a land use (BasinSim Manual, 2000).

As we can see from the soils map (Figure 3-16) the main soils hydrologic group is A which has low runoff potential and high infiltration rates even when thoroughly wetted. These soils are chiefly deep, well to excessively drained sands or gravels. They have a high rate of water transmission ( $>0.75 \mathrm{~cm} / \mathrm{hr}$ ) (Soil Conservation Service, 1986). 
Figure 3-16.

Proposed Bay Creek Developmet Soils Map

Soils map

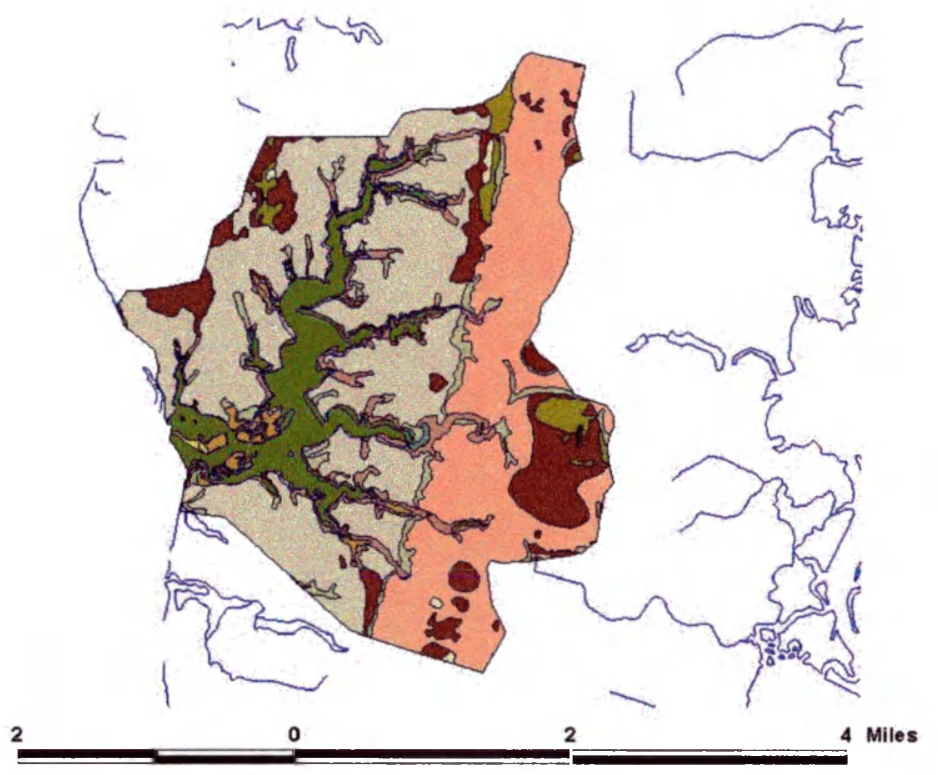

of the study

area

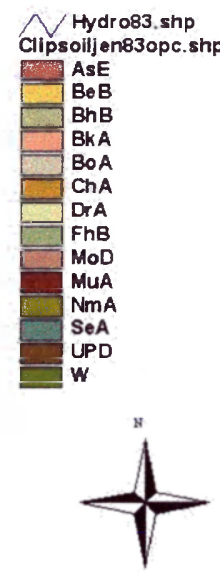

\section{Nutrient Data}

The first data in the nutrient file are concentrations of nitrogen $(\mathrm{N})$ and phosphorus (P) in local sediments and groundwater, and information on agricultural manure application: Sediment $\mathrm{N}$ and $\mathrm{P}$ were determined by getting $\%$ sediment weight from maps (GWLF, 1992). Groundwater N and P was determined according to the tables in GWLF manual (1990). In the investigation area farmers usually do not use manure as a fertilizer (personal communication, Tim Holloway, Fred Diem) so the values for manure application were chosen 0 . Fertilizer application numbers chosen were typical for agriculture practices.

The next section of the nutrient file contains information for calculating $\mathrm{N}$ and $\mathrm{P}$ runoff from various land use types. The first portion contains $\mathrm{N}$ and $\mathrm{P}$ concentrations in runoff for rural land types only. Typical concentrations (mg/l) can be found in the 
GWLF manual (2000). Immediately following are listed the urban land use types. The calculation for these land uses takes a different parameter, called "contaminant accumulation rate", in kilograms per hectare per day. The next required section of the file has information about point sources of $\mathrm{N}$ and $\mathrm{P}$ within the watershed. As far as it is known there are no main point sources in the watershed. So the values chosen were 0. The final part of the nutrient file is the information about septic systems. At the moment there are very few septic systems in the area because the land is mainly used for agriculture and there are not many human settlements. For simplicity it was assumed that there were no septic systems in the area.

While creating different development scenarios the general input file format was kept the same in all files. First Baseline scenario file was created and after that all other files were adapted. Parameters that were changed in Agriculture scenario input files are presented in Table 3-4.

Table 3-4. Changes in the input files (BasinSim) for Agriculture scenario

\section{Parameters that were changed in Agriculture scenario input files}

This represents one form of worst-case scenario.

Transport File:

- ET cover coefficient: recalculated weighted average based on agricultural and urban land uses only

- Any agricultural, urban, water and wetland categories remained unchanged

- The number and order of the land uses remained the same, but forested areas were renamed to general "Agriculture".

- The soil curve number and KLSCP for forested areas changed to a generalized (average) number for agricultural land

Nutrient File:

- Groundwater $\mathrm{N}$ and $\mathrm{P}$ changed to that of agricultural loads

- Concentration of $\mathrm{N}$ and $\mathrm{P}$ in runoff: change Forested values to match those of agricultural land

- Build-up rates for urban land uses unchanged 
For Forest types coefficients (for example evapotranspiration) are assumed to be

the same. In other words the new forest was not differentiated into different types.

Parameters that were changed in Forest scenario input files are presented in Table 3-5.

Table 3-5. Changes in the input files (BasinSim) for Forest scenario

Parameters that were changed in Forest scenario input files

This represent one form of pristine conditions scenario

Transport File:

- First seven lines of input file remained the same

- ET cover coefficient (in next 12 lines) changes to that of forest ( 1 in growing season, 0.583 in non-growing season), while the other numbers in this section remain the same

- Forested, water, and wetland categories remain unchanged

- The number and order of the land uses kept the same, but renamed the agriculture and urban areas to "Forest"

- The soil curve number and KLSCP for agricultural and urban areas changed to the numbers for non-harvested forest

Nutrient File:

- Changed groundwater $\mathrm{N}$ and $\mathrm{P}$ to that of Forest

- Concentration of $\mathrm{N}$ and $\mathrm{P}$ in runoff: Agriculture values were changed to match those of non-harvested forest

- Build-up rates for urban land uses changed to the lowest values given in GWLF manual

No point sources

The parameters that have been change from the Baseline scenario for the Golf

Course scenario are presented in Table 3-6

Table 3-6. Changes in the input files (BasinSim) for Golf Course scenario

Parameters that were changed in Golf Course scenario input files

Transport File:

- First seven lines of input file remain the same as the Base line scenario

- ET cover coefficient (in next 12 lines) changed to one that represents $25 \%$ forest, $30 \%$ grassland, $40 \%$ residential area while the other numbers in this section remain the same

- Forested, water, and wetland categories remain unchanged

- The number and order of the land uses remained the same, but renamed "agriculture" to "grassland" and urban areas were increased

- The soil curve number and KLSCP for agricultural and urban areas change to the numbers for mixed agriculture residential area and forest

Nutrient File:

- Changed groundwater $\mathrm{N}$ and $\mathrm{P}$

- The values of fertilizer application changed to those of golf course for grassland area.

- Concentration of $\mathrm{N}$ and $\mathrm{P}$ in runoff: all values changed to match those of golf course fertilizer application.

- Build-up rates for urban land uses changed to the values for a residential area. Half of the urban area was considered as high intensity development and the other half as low intensity development.

- No point sources

- There will be no septic systems in the proposed development 
For the Baseline scenario in the Bay Creek watershed there were no septic systems or the influence that they were making was deemed negligible. The population density was very low $(<1 \%)$. In the proposed development area (Bay creek

Development) all sewage will be collected into one pipe and will be directed to the Cape Charles Sewage Treatment Plant. So again there will be no threat of nutrients from septic systems. In the case of the Agricultural scenario it was assumed that no new people would move to the area. According to the Chesapeake Bay Program database there are no significant point sources in the Old Plantation Creek (Chesapeake Bay Program. 2000. Watershed Profiles)

\section{Tidal Prism Water Quality Model}

Simulation results were taken from BasinSim model and were input to the Tidal Prism Water Quality Model (TPWQM). TPWQM was used as a tool for assessing pollutant concentrations in the water column of the Old Plantation Creek. Although the computer model is designed to model point source pollution from the land, the program was used for simulation of the non point source pollution. Albert Y. Kuo and SungChan Kim (pers. communication) suggested that the model could be used for non point source pollution if we treat non point source loads as point source loads. The creek was divided into segments, which allowed for better analysis of pollutant concentrations in different parts of the creek.

In this research, the Nutrient-Sensitive version of the TPWQM was used, which can include the following ten water quality state variables: 1) algae, 2) organic phosphorus, 3) inorganic phosphorus, 4) organic nitrogen, 5) ammonium nitrogen, 6) 
nitrate nitrogen, 7) organic carbon, 8) dissolved oxygen, 9) fecal coliform bacteria 10) salinity. In this project algae, nitrogen and phosphorus were examined, because these are the parameters important for SAV.

The state variables and their interactions in the nutrient-sensitive version are found in TPWQM users manual (Kuo et al. 2000). Total algal biomass is quantified using one state variable. Organic matter for each of phosphorus, nitrogen and carbon also is represented by one state variable, which includes both particulate and dissolved organic matter. The nitrate state variable represents the sum of nitrate and nitrite nitrogen. The external sources including point and non point source inputs are taken care of in the formulations of physical transport processes.

Model Features:

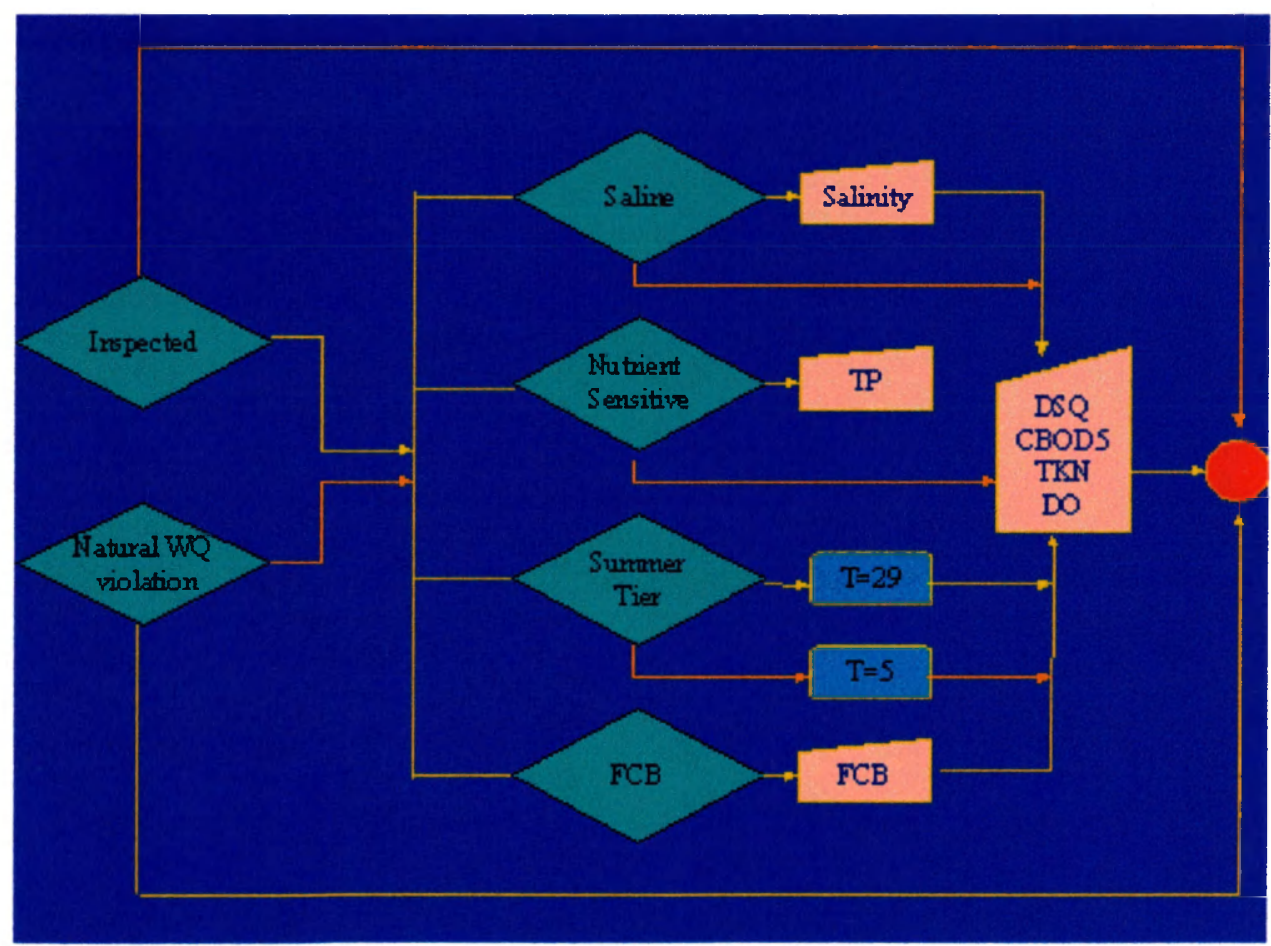

Figure 3-17. The flowchart of the TPWQM (from TPWQM users manual) 
The flowchart of the TPWQM components is shown in Figure 3-17. T he model has four options: (1) saline or freshwater system; (2) nutrient sensitive or insensitive cases; (3) summer season or winter season; and (4) including fecal coliform bacteria (FCB) or not. For the basin information, salinity at the mouth and fresh water discharge rate to all the branches are needed. For each point source, the required information includes location, discharge rate, 5 day carbonaceous biochemical oxygen demand $\left(\mathrm{CBOD}_{5}\right)$, total Kjeldahl nitrogen (TKN), and dissolved oxygen (DO), and total phosphorous (TP) or (FCB).

\section{Input files (TPWQM)}

Data that were input to the TPWQM are as follows:

For the non point source pollution we assume that water quality is not violated naturally. Salinity at the mouth of the creek was $22 \mathrm{ppt}$. Freshwater discharge in millions gallons per day (MGD) was different in different scenarios and different segments. In the analysis it was assumed that there are three point source polluters (three segments of the watershed), draining into three different parts of the creek for each scenario. In the case when the pollution was calculated only from one source, all three sources (pollution from all three segments) were added by multiplying each segment pollution by the coefficient of the area that was drained.

The model is designed to calculate the point source impacts to the creek and does not take into consideration the pollution from the whole watershed: we have to assume that part of the runoff to the creek (from the watershed not affected by development) will come as freshwater containing undefined pollution. In the final phase of data input the model ask to input the CBOD5, nitrogen and phosphorus concentrations in the runoff. 
For the CBOD5 and DO the value $10 \mathrm{mg} / \mathrm{l}$ was chosen (pers. communication A. Kuo).

In the case of nitrogen and phosphorus the values were different in each case. Nutrients

and freshwater input parameters are presented in Table 3-7.

\section{Table 3-7. TPWQM input parameters}

\begin{tabular}{|c|c|c|c|c|c|c|c|c|c|c|c|c|}
\hline Nutrients & $\mathrm{mg} / \mathrm{l}$ & & & & & & & & Freshwater & MGD & & \\
\hline & baseline 1 & & baseline2 & & baseline 3 & & total baselin & & baseline 1 & baseline2 & baseline3 & 3 total \\
\hline & TN & TP & $T N$ & TP & TN & TP & TN & TP & & & & \\
\hline march & 0.685 & \begin{tabular}{l|l|}
5 & 0.0335 \\
\end{tabular} & 1.551 & 0.0947 & 0.997 & $\quad 0.0528$ & 0.968 & $8 \quad 0.0528$ & 2.7 & 1.3 & 1.2 & 5.20 \\
\hline monthly average & 0.496 & 0.0234 & 1.757 & 0.1182 & 0.905 & 0.0428 & 0.897 & 0.0508 & 1.3 & 0.6 & 0.6 & 2.50 \\
\hline & agri1 & & agri2 & & agri3 & & total agri & & agri1 & agri2 & agri3 & total \\
\hline & TN & TP & TN & TP & TN & TP & TN & TP & & & & \\
\hline march & 3.203 & $\begin{array}{ll}3 & 0.0628 \\
\end{array}$ & 4.324 & 0.1305 & 4.383 & 0.0913 & 3.755 & $5 \quad 0.0859$ & 2.8 & 1.4 & 1.3 & 5.50 \\
\hline monthly average & 2.333 & 0.0446 & $6 \quad 3.924$ & 0.1444 & $4 \quad 3.980$ & 0.0764 & $\quad 3.110$ & 0.0762 & 1.3 & 0.6 & 0.6 & 6 $\quad 2.50$ \\
\hline & forest1 & & forest2 & & forest 3 & & total forest & & forest 1 & forest2 & forest3 & total \\
\hline & TN & TP & TN & TP & TN & TP & TN & TP & & & & \\
\hline march & 0.119 & $9 \quad 0.0038$ & 0.180 & 0.0057 & 0.164 & 0.0052 & 0.144 & $4 \quad 0.0046$ & 2.7 & 1.3 & 1.2 & 5.20 \\
\hline monthly average & 0.086 & 0.0027 & 0.175 & 0.0055 & 0.149 & 0.0047 & 0.123 & 0.0039 & 1.3 & 0.6 & 0.6 & 2.50 \\
\hline & golf1 & & golf2 & & golf3 & & total golf & & golf1 & golf2 & golf3 & total \\
\hline & TN & TP & TN & TP & TN & TP & TN & TP & & & & \\
\hline march & 1.105 & 0.0728 & 1.774 & 0.1460 & 1.130 & $\quad 0.0719$ & 1.271 & $1 \quad 0.0902$ & 2.8 & 1.4 & 1.6 & 5.80 \\
\hline monthly average & 1.214 & 0.0973 & 2.260 & 0.2113 & 1.215 & 0.0922 & 1.465 & 0.1234 & 1.3 & 0.6 & 0.7 & 2.60 \\
\hline & OPC1 & & OPC2 & & OPC3 & & total OPC & & OPC1 & OPC2 & OPC3 & total \\
\hline & $\mathrm{TN}$ & TP & $\mathrm{TN}$ & TP & $\mathrm{TN}$ & TP & TN & TP & & & & \\
\hline march & 0.833 & 0.0381 & 1.431 & 0.0883 & 1.115 & 0.0584 & 1.044 & 0.0550 & 10.5 & 5 & 4.7 & 20.20 \\
\hline monthly average & 0.696 & 0.0305 & 1.597 & 0.1039 & 1.087 & 0.0516 & 1.006 & 0.0532 & 4.9 & 2.3 & 2.1 & 9.30 \\
\hline
\end{tabular}




\subsection{Environmental Results (BasinSim)}

Monthly freshwater flow data was compared with the BasinSim simulation results to evaluate the predictive power of the model. Stream flow data were also used for hydrologic calibration. Observed stream flow was normalized to the area of the watershed. The regression coefficient (the coefficient of determination) $\left(r^{2}\right.$ or $\left.R^{2}\right)$ for different scenarios and different segments of the watershed fell into the range between 0.6 and 0.67 . The comparison of predicted and observed stream flow data is presented in Figure 3-18:

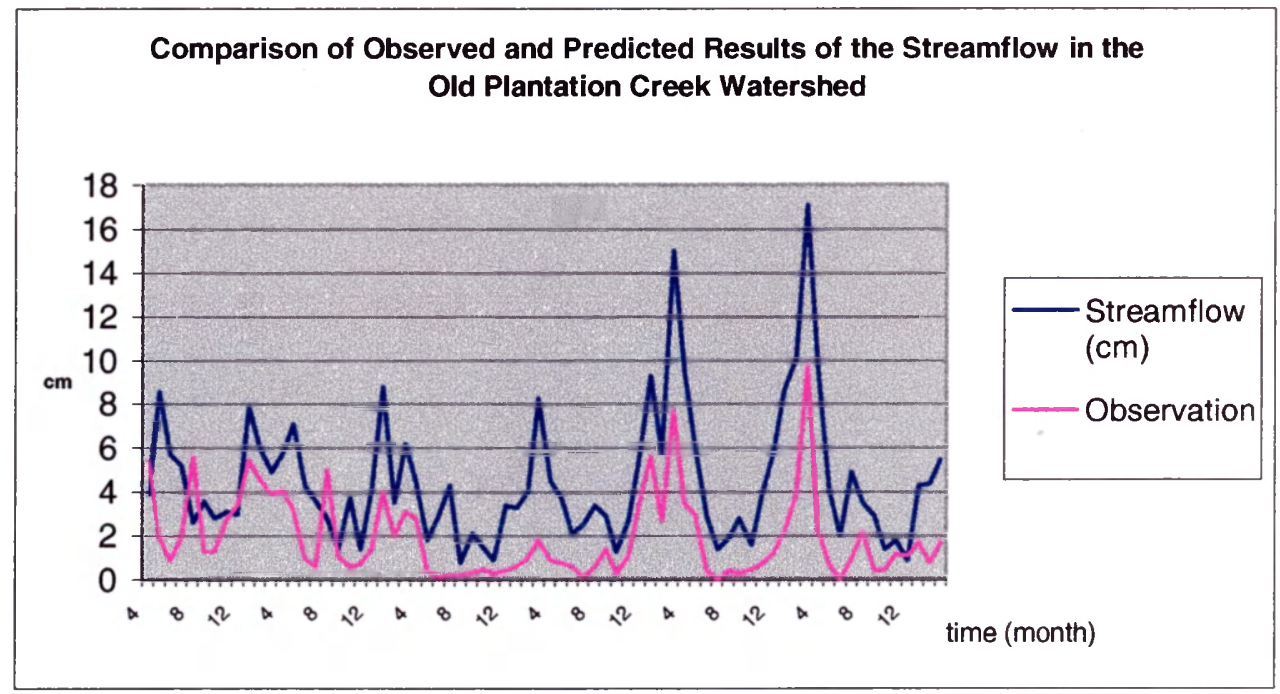

Figure 3-18. Comparison of observed and predicted stream flow data

(source: USGS at http://waterdata.usgs.gov/nwis-w/US/)

\section{Loading (BasinSim)}

An example of data output is provided in Table 3-8. The following principal variables are given in the BasinSim output files:

Monthly Stream flow - "Stream (cm)" in the table

Monthly Watershed Erosion and Sediment Yield - "Erosion (t)" and "Sediment (t)" 
Monthly Total Nitrogen and Phosphorus Loads in Stream flow - "Tot N" and "Tot P" Annual Erosion from Each Land Use - "Erosion (t/h)"

Annual Nitrogen and Phosphorus Loads from Each Land Use -, "tot $\mathrm{N} \mathrm{kg",} \mathrm{"tot} \mathrm{P} \mathrm{kg"}$

Monthly Precipitation and Evapotranspiration - "Precip $(\mathrm{cm})$ ", "Et $(\mathrm{cm})$ "

Monthly Ground Water Discharge to Stream flow - "Groundwater $(\mathrm{cm})$ "

Monthly Watershed Runoff - "Runoff $(\mathrm{cm})$ "

Monthly Dissolved Nitrogen and Phosphorus Loads in Stream flow - "Dis. N (kg)", "Dis. P $(\mathrm{kg})$ "

Annual Dissolved Nitrogen and Phosphorus Loads from Each Land Use - "dis N kg", "dis P kg"

Table 3-8. Example output table from BasinSim (Baseline scenario, first segment)

\begin{tabular}{|c|c|c|c|c|c|c|c|}
\hline baseline 1 & Precip (cm) & Et $(\mathrm{cm})$ & $\begin{array}{l}\text { Jroundwater } \\
\qquad(\mathrm{cm})\end{array}$ & Runoff $(\mathrm{cm})$ & Stream $(\mathrm{cm})$ & & $\begin{array}{l}\text { area }\left(\mathrm{m}^{2}\right) \\
3314900\end{array}$ \\
\hline APR & 7.3 & 6.1 & 4.4 & 1.9 & 6.3 & & \\
\hline MAY & 11.4 & 8.9 & 2.2 & 3.1 & 5.3 & & \\
\hline JUNE & 8.0 & 10.6 & 1.2 & 2.1 & 3.3 & & 6 year means \\
\hline JULY & 12.4 & 8.6 & 0.4 & 3.3 & 3.7 & & \\
\hline AUG & 9.1 & 7.6 & 0.1 & 2.4 & 2.5 & & \\
\hline SEPT & 9.7 & 5.0 & 0.0 & 2.6 & 2.6 & & \\
\hline OCT & 7.7 & 4.2 & 0.0 & 2.1 & 2.1 & & \\
\hline NOV & 8.0 & 1.7 & 0.2 & 2.2 & 2.3 & & \\
\hline DEC & 9.4 & 1.0 & 1.4 & 2.4 & 3.8 & & \\
\hline JAN & 9.2 & 1.0 & 4.6 & 2.5 & 7.1 & & \\
\hline FEB & 6.8 & 1.2 & 3.8 & 1.8 & 5.6 & & \\
\hline MAR & 13.3 & 2.3 & 5.9 & 3.6 & 9.5 & & \\
\hline annual & 112.4 & 58.2 & 24.0 & 30.1 & 54.1 & & \\
\hline & Erosion $(t)$ & Sediment $(t)$ & Dis. $N(\mathrm{~kg})$ & Tot. $N(\mathrm{~kg})$ & Dis. $P(\mathrm{~kg})$ & Tot. $P(\mathrm{~kg})$ & \\
\hline APR & 2.4 & 0.0 & 157.4 & 158.3 & 4.2 & 4.4 & \\
\hline MAY & 6.2 & 0.4 & 78.4 & 80.9 & 2.1 & 3.0 & \\
\hline JUNE & 2.7 & 0.2 & 42.0 & 43.2 & 1.1 & 1.6 & \\
\hline JULY & 5.4 & 0.7 & 12.5 & 15.0 & 0.3 & 1.7 & \\
\hline$A \cup G$ & 3.9 & 0.6 & 3.5 & 5.4 & 0.1 & 1.2 & \\
\hline SEPT & 3.9 & 0.8 & 1.0 & 3.4 & 0.0 & 1.6 & \\
\hline OCT & 1.5 & 0.8 & 0.3 & 2.4 & 0.0 & 1.6 & \\
\hline NOV & 2.0 & 0.8 & 5.8 & 8.4 & 0.2 & 1.8 & \\
\hline DEC & 1.4 & 0.9 & 49.7 & 52.6 & 1.3 & 3.1 & \\
\hline JAN & 1.3 & 1.1 & 163.1 & 166.5 & 4.4 & 6.5 & \\
\hline FEB & 0.8 & 0.7 & 135.5 & 137.5 & 3.6 & 4.9 & \\
\hline MAR & 3.0 & 2.6 & 209.5 & 215.3 & 5.6 & 10.5 & \\
\hline annual & 34.5 & 9.5 & 858.8 & 888.8 & 23.1 & 41.9 & \\
\hline & Area ha & Runoff cm & Erosion $\mathrm{t} / \mathrm{h}$ & dis $\mathrm{N} \mathrm{kg}$ & tot $\mathrm{N} \mathrm{kg}$ & dis $\mathrm{P} \mathrm{kg}$ & tot $P \mathrm{~kg}$ \\
\hline DeciduousForest & 42.97 & 0.00343 & 0.000 & 0.00044 & 0.00044 & 0.00001 & 0.00001 \\
\hline EvergreenForest & 32.68 & 0.00343 & 0.000 & 0.00213 & 0.00213 & 0.00007 & 0.00007 \\
\hline MixedForest & 3.12 & 0.00343 & 0.000 & 0.00020 & 0.00020 & 0.00001 & 0.00001 \\
\hline MixedShrub/Scrub & 0.29 & 0.00343 & 0.000 & 0.00002 & 0.00002 & 0.000 & 0.000 \\
\hline PalustrineForest & 2.26 & 0.00343 & 0.000 & 0.00015 & 0.00015 & 0.000 & 0.000 \\
\hline EstuarEmergWetl & 13.38 & 112.29830 & 0.000 & 0.000 & 0.000 & 0.000 & 0.000 \\
\hline TidalFlats & 2.91 & 112.29830 & 0.000 & 0.000 & 0.000 & 0.000 & 0.000 \\
\hline Cropland & 121.75 & 0.00343 & 0.16321 & 0.07517 & 7.78104 & 0.01086 & 10.01748 \\
\hline Grassland & 35.76 & 0.00343 & 0.40787 & 0.03680 & 5.69307 & 0.00307 & 7.34814 \\
\hline Water & 70.92 & 112.29830 & 0.000 & 0.000 & 0.000 & 0.000 & 0.000 \\
\hline Exposed & 3.44 & 21.25350 & 0.000 & 0.000 & 0.000 & 0.000 & 0.000 \\
\hline Hi-Urban & 1.65 & 64.46420 & 0.000 & 0.000 & 12.90377 & 0.000 & 1.43375 \\
\hline Lo-Urban & 0.36 & 1.56817 & 0.000 & 0.000 & 3.80730 & 0.000 & 0.04653 \\
\hline groundwater & & & & 858.65 & 858.65 & 23.06 & 23.06 \\
\hline
\end{tabular}


Nitrogen and Phosphorus Loads

While looking into each segment separately we can see the difference in each segment: e.g. the area of the first segment is twice as large as the second segment in the Baseline scenario but loads from the second segment are twice these of the smaller first segment, which shows that it is not the area, but what is in this area (what land use dominates) that matters for pollutant loadings. (Average numbers showing what is coming from each scenario are presented in Figures 3-19, 3-20 and 3-25).

Results show that we could expect highest nitrogen loads from the Agriculture scenario: in the First segment we expect an increase in nitrogen loads equal to that of the whole watershed - i.e., more than 3 tons. The relative impact of the Baseline scenario, compared to the "Whole" watershed loadings, reflects the area ratio, which is $1 / 4$. In the case of the Golf Course scenario we expect that nutrient loads would double compared to the Baseline scenario. The lowest loads are expected to come from the Forest scenario.

A different picture can be seen in the case of phosphorus. The highest loads are expected to come from the Golf Course scenario where loads are higher even than in the Agriculture case. The Golf Course scenario will contribute almost 1/3 of the phosphorus loads to the creek (compared to the "Whole" watershed). Phosphorus loads from the Forest scenario would not exceed $100 \mathrm{~kg}$ per year. Nutrients loadings are presented in Figures 3-19 and 3-20: 


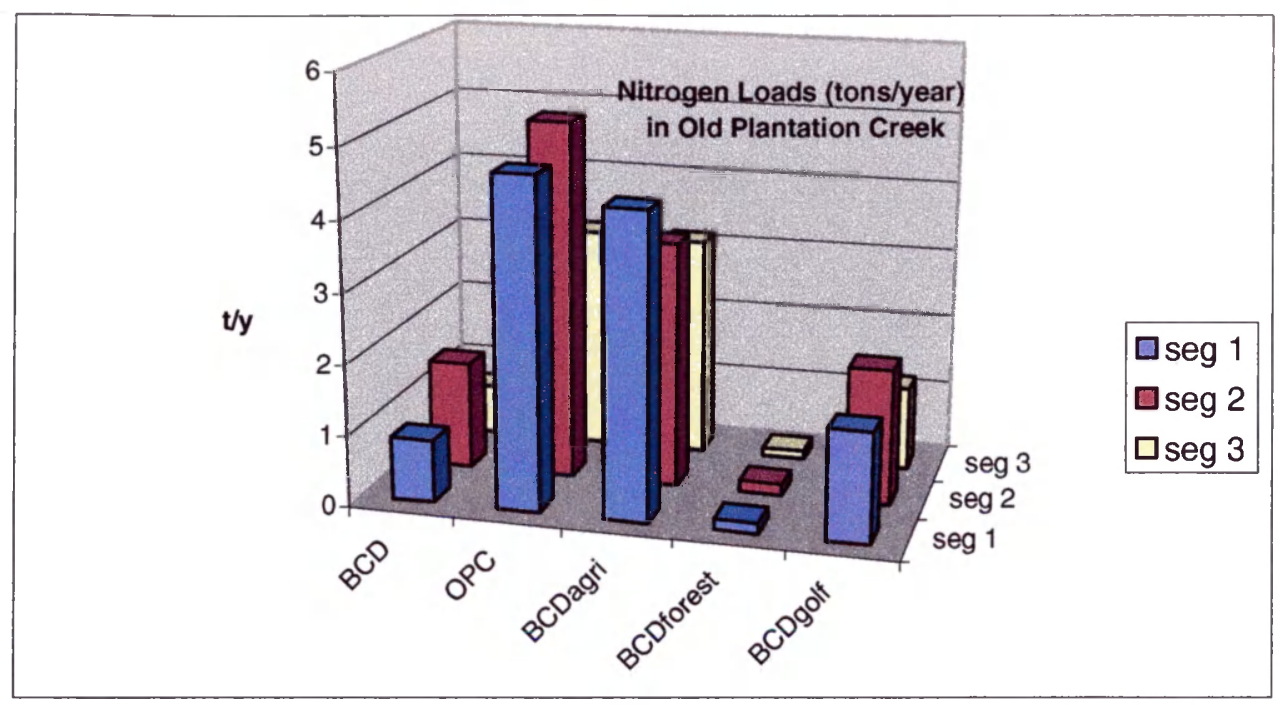

Figure 3-19. Yearly Nitrogen Loads from the Old Plantation Creek watershed under different scenarios.

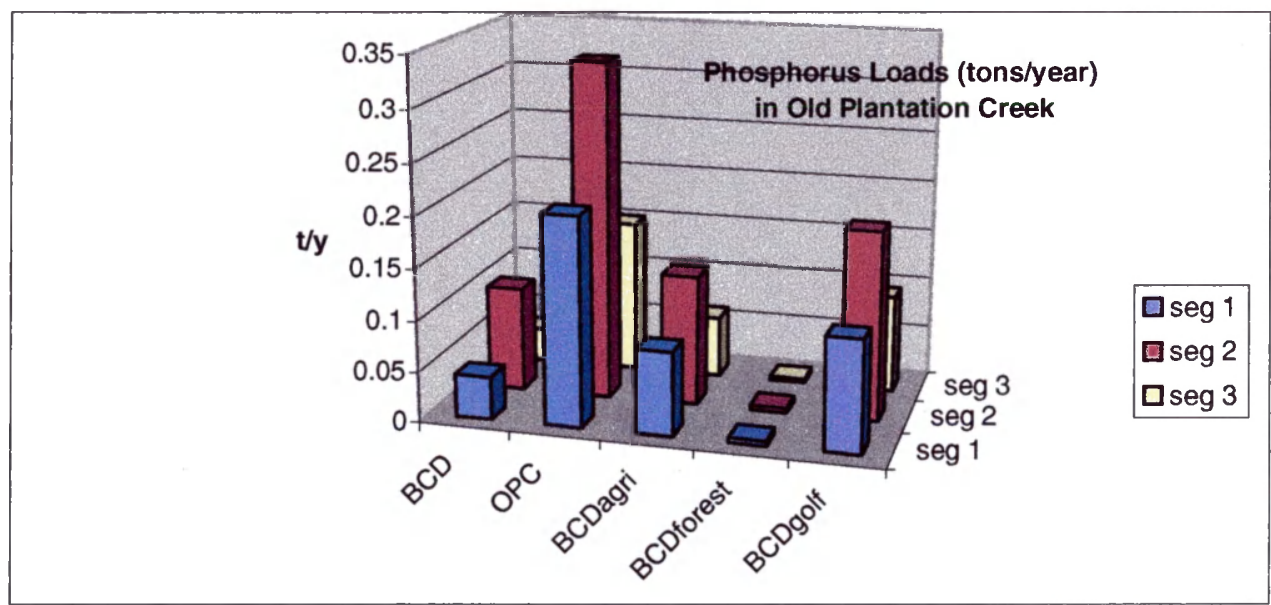

Figure 3-20. Yearly Phosphorus Loads from the Old Plantation Creek watershed under different scenarios. 
Weather data indicate that the amount of freshwater entering the creek varies from year to year. We also could expect that nutrients dynamics are affected by those changes. The freshwater input also varies by season. For example in 1993 freshwater inputs were the highest through the study time (from 1989 to 1997). The year 1991 was chosen as representative with no significant freshwater peak and relatively low freshwater inputs (see Figure 3-18). The results show that, in fact, the loads in a high freshwater flow year are higher (Figure 3-21, 3-22)

Monthly loadings data show that the seasonal flux of nutrients to the creek has especially high values in spring (March and April) and winter (January and February) (Figures from 3-21 to 3-24). The lowest loads were observed in summer (August) for phosphorus and autumn (September and October) for nitrogen.
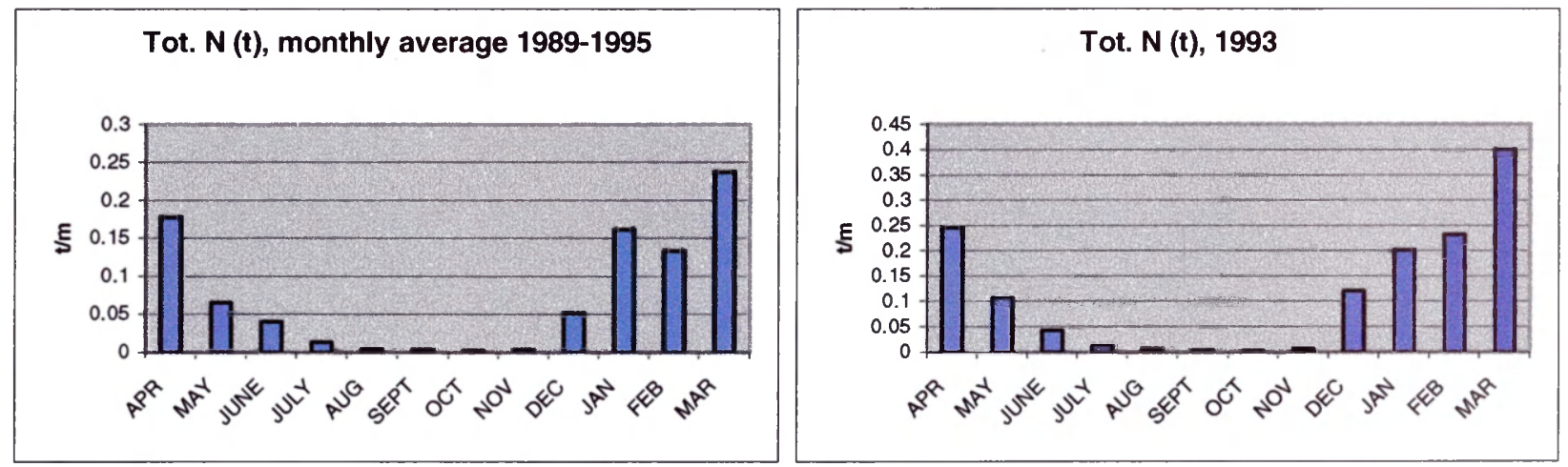

Figure 3-21. Monthly average (years Figure 3-22. Monthly total nitrogen 1989- 1995) nitrogen loads from loads: Baseline scenario, segment 1 Baseline scenario, segment 1 

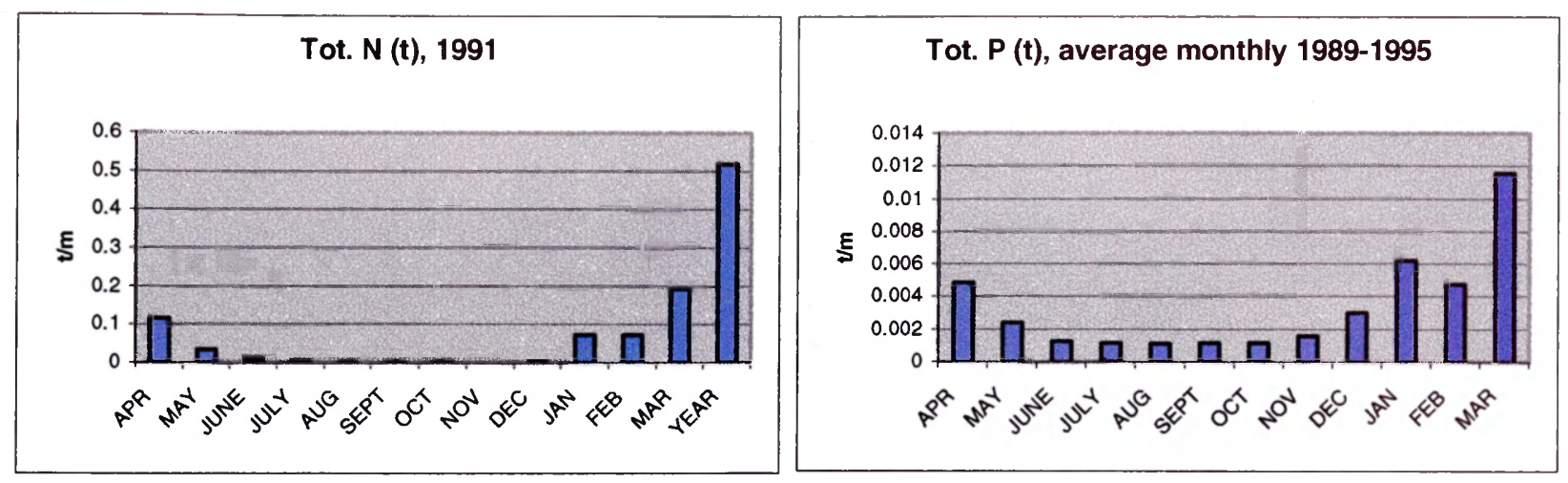

Figure 3-23. Monthly total nitrogen

Figure 3-24. Monthly Average (years

loads: Baseline scenario, segment 1

1989- 1995) Phosphorus Loads: Baseline

scenario, segment 1)

In the case of suspended solids, largest loads are expected from the Agriculture scenario. For the Baseline and Golf Course scenarios solids loads are expected to be almost the same. Forest scenario solids loads are expected to be only a few kilograms per year (Fig. 3-25). 


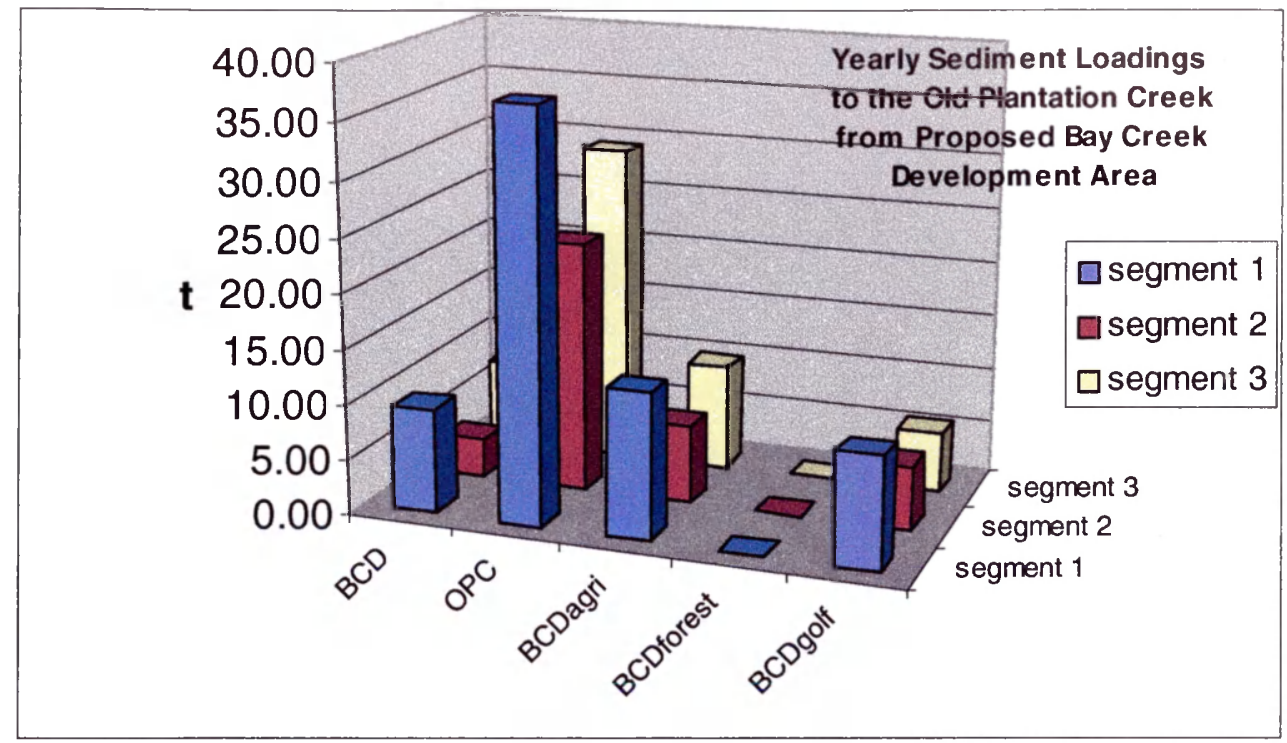

Figure 3-25. Yearly sediment loads from Segments 1, 2 and 3

Monthly sediment loads exhibit a different picture than nutrients, with the peak occurring in March. Unlike nutrients in April, suspended solids loads are negligible (Figure 3-26 and 3-27). Loads fluctuate from April to August then have a tendency to increase slightly every month until January.

While looking into monthly data (Figure 3-27) from one year (as opposed to a 6 year average) loads seem to follow runoff patterns. (The year 1991 was chosen as a moderate year regarding precipitation). 


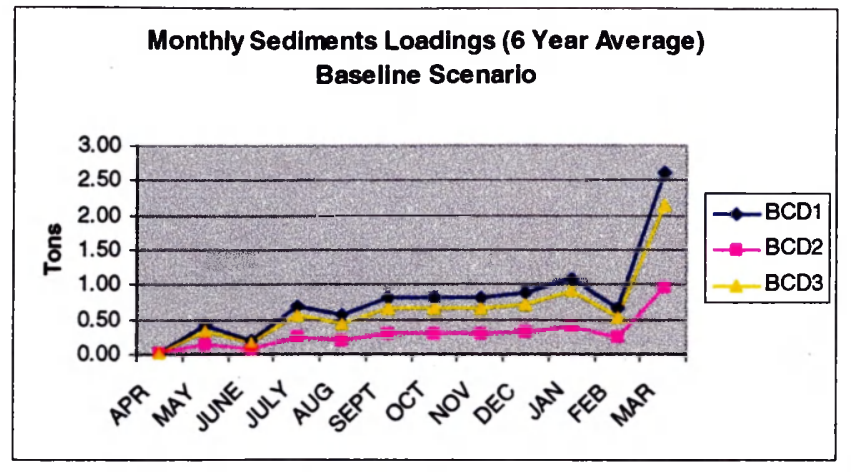

Figure 3-26. Monthly sediment loads

from Segments 1, 2 and 3

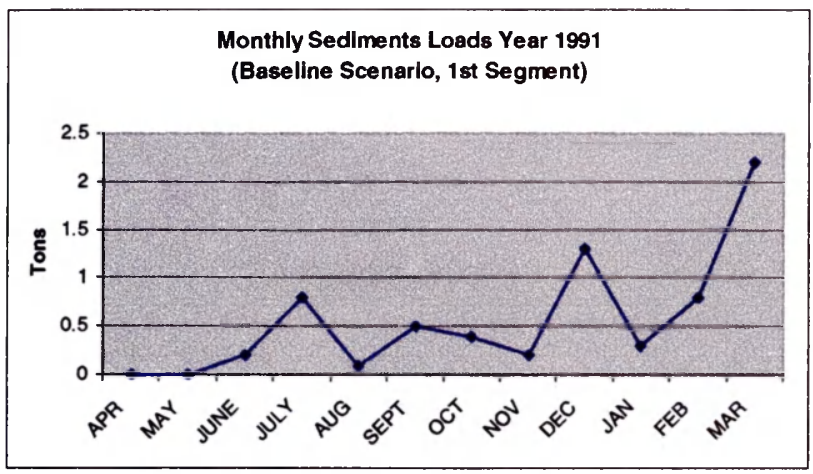

Figure 3-27. Monthly sediment loads:

segment 1 


\section{Nitrogen and Phosphorus concentrations in runoff (BasinSim)}

Nitrogen and phosphorus concentrations in the runoff reflect not only loadings amounts but also incorporate freshwater inputs carrying those nutrients to the system.

The general pattern is the same as in actual loading with the highest values reached in the Agricultural scenario and lowest in the Forest scenario. The highest concentrations in the year are expected to be in March. Nitrogen concentrations are higher in March by 0.5 mg/l (Figures 3-28 and 3-29). In the case of phosphorus the loading, concentrations are higher for March in the Agriculture and Forest scenarios, but lower in Golf Course and almost the same in the Baseline scenario cases (Figures 3-30 and 3-31).

Figures 3-28, 3-29. Nitrogen concentrations in Baseline scenario: March and monthly
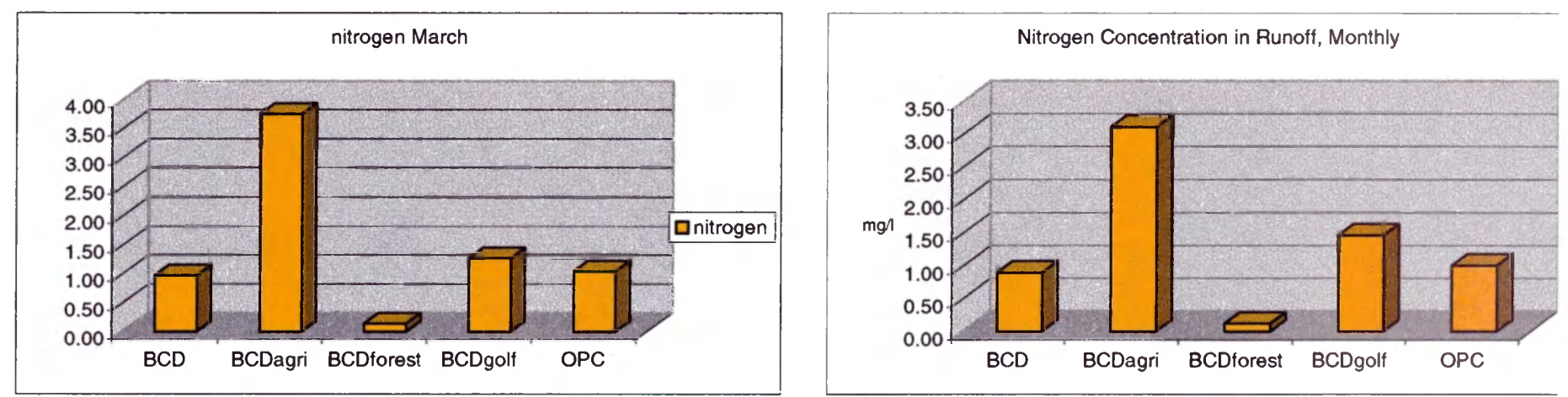

Figures 3-30, 3-31. Phosphorus concentrations in Baseline scenario: March and monthly
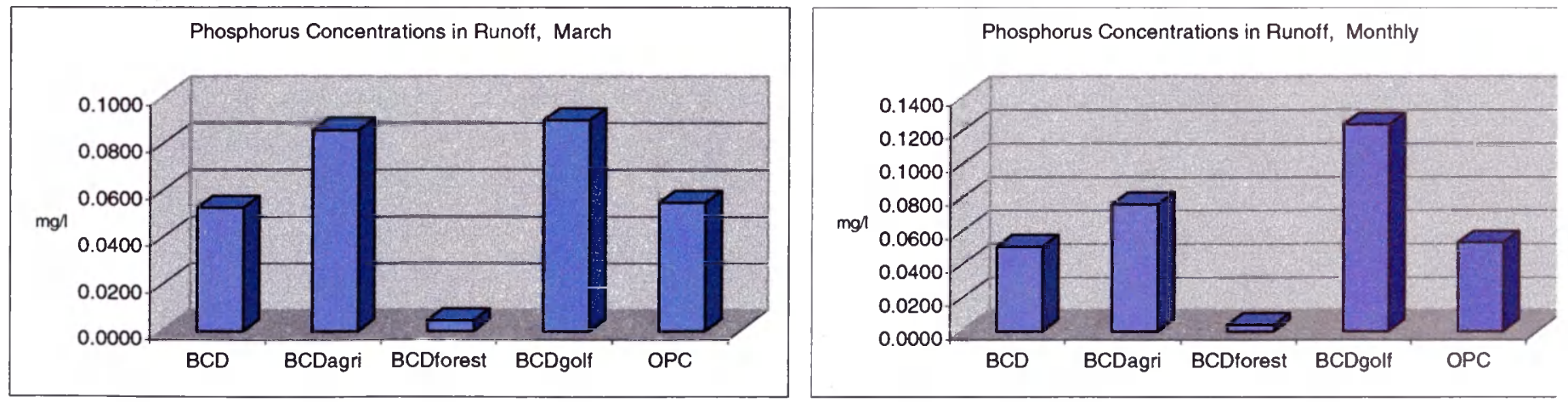


\subsection{Environmental Results (TPWQM)}

Tidal Prism Water Quality Model takes the concentration in runoff and runoff volumes and gives out the output pollutant concentrations in the water column of the creek taking into consideration geometry, runoff water volume, and water volume in the creek as well as biological processes such as assimilation of nutrients, phytoplankton amounts, etc. (more in APPENDIX B). The model is run 100 times/100 tidal cycles before presenting the results (concentrations of materials in water column). Also the model examines summer conditions (high temperature) under the assumption that such conditions present the highest possibility of contamination of a water body with excess phytoplankton and its consequences (hypoxia, shading, etc.). In wintertime the nutrient loads might be high but it would not have a significant impact on the ecosystem.

Tidal Prism Water Quality Model outputs show that the highest Chl "a" concentrations could be expected from the Agriculture scenario. There is a slight increase in Chl "a" over the Baseline scenario in the Golf Course case. Forest scenario concentrations are expected to be the lowest. For comparison, loads from the Agriculture scenario would induce phytoplankton blooms of nearly the same magnitude as we could expect from the "Whole" watershed. Chl "a" average concentrations in the creek under different development scenarios are presented in Figure 3-32.

The highest concentrations of nitrogen are expected to be in the Agriculture scenario, the lowest in Forest (Figure 3-33). Golf Course loadings will increase the nitrogen concentration in the creek compared to the Baseline scenario. In the case of phosphorus (Figure 3-34) the highest concentrations are expected to be in Forest scenario 
with the lowest Agriculture. In the Golf Course scenario, concentrations are expected to be almost as high as in the Forest scenario leaving the Baseline line scenario in the third position.

The values in figures 3-32 to 3-34 show the nutrient concentrations calculated after taking into consideration the proposed development area loadings plus the Whole watershed loadings. Each scenario reflects the impacts of the whole watershed plus the difference that is expected from different development scenarios. (It is possible to run the TPWQ model considering only the changing parameters in the proposed development area and assuming that loadings from the Whole watershed will not have an influence on water quality in the creek (water quality will not be violated), but the results show that in doing this we are generating large errors.) 


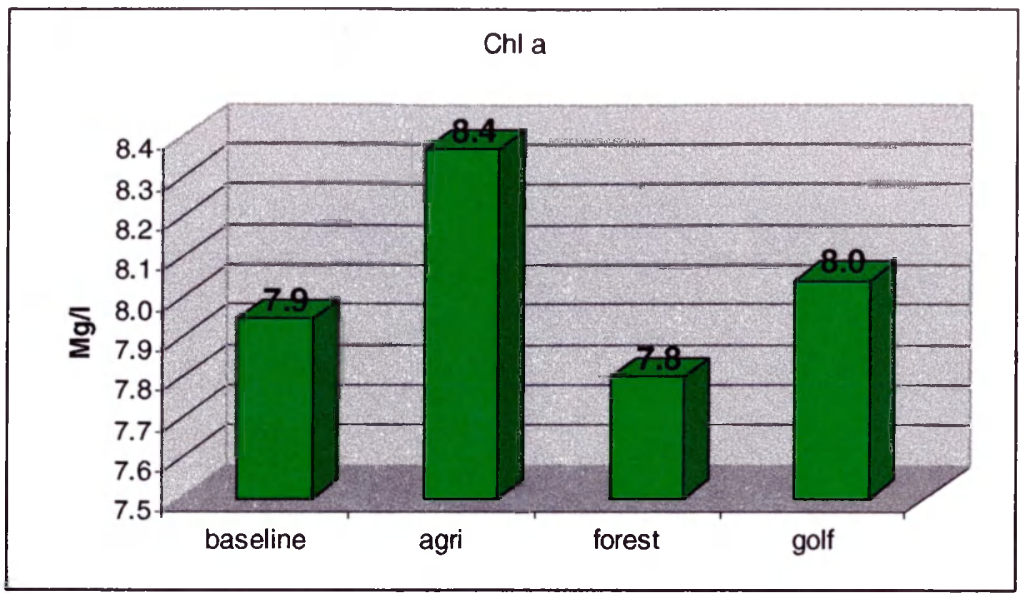

Figure 3-32. Chlorophyll "a" concentrations in all scenarios in Old Plantation Creek

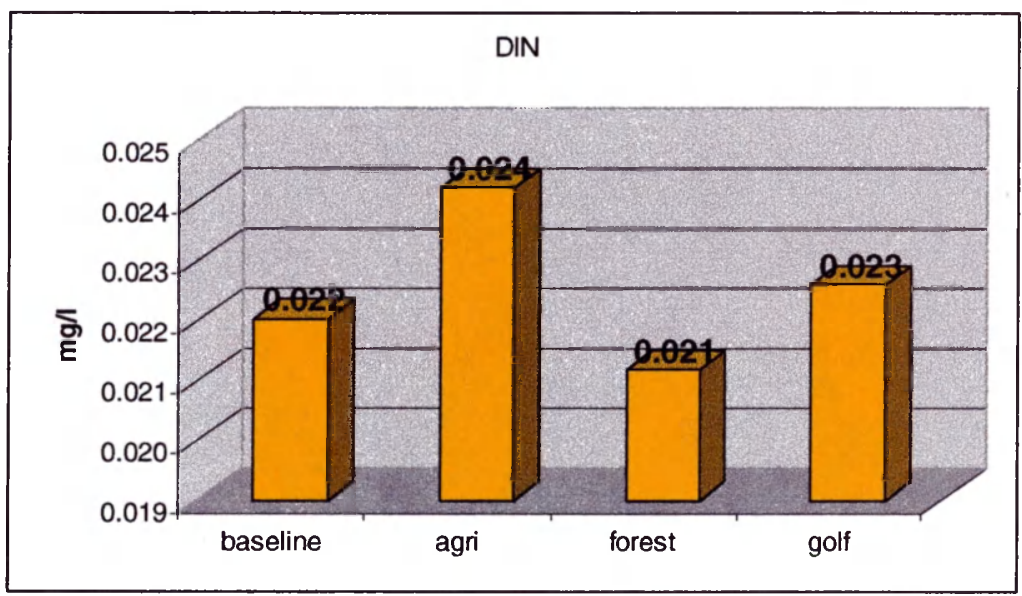

Figure 3-33. Dissolved inorganic nitrogen concentrations in all scenarios in O. P. Creek

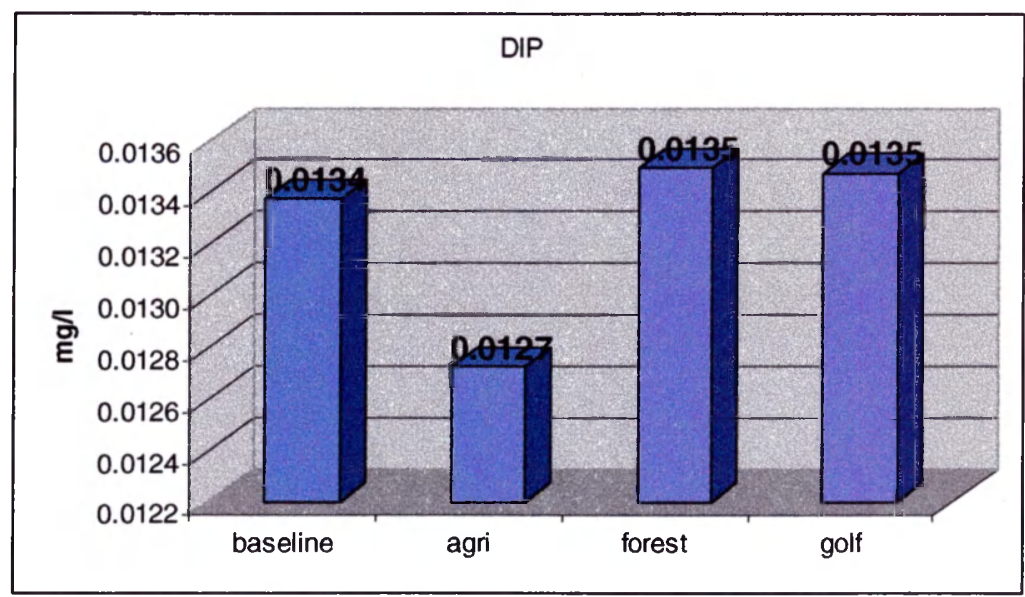

Figure 3-34. Dissolved inorganic phosphorus concentrations in all scenarios in Old Plantation Creek 
The model was run for the loadings/concentrations predicted in March. It is at this time of the year when loadings are the highest, because of the lack of vegetation on the ground and high rainfall. We can see that in March in Agriculture the Chl "a" concentrations (Figure 3-35) in the creek are increasing upstream. The nitrogen shows concentrations at their lowest in the middle of the creek. The phosphorus concentrations are increasing upstream (Figure 3-37). Looking at different segments we see that Chlorophyll "a" follows the phosphorus trend more closely than that of nitrogen.

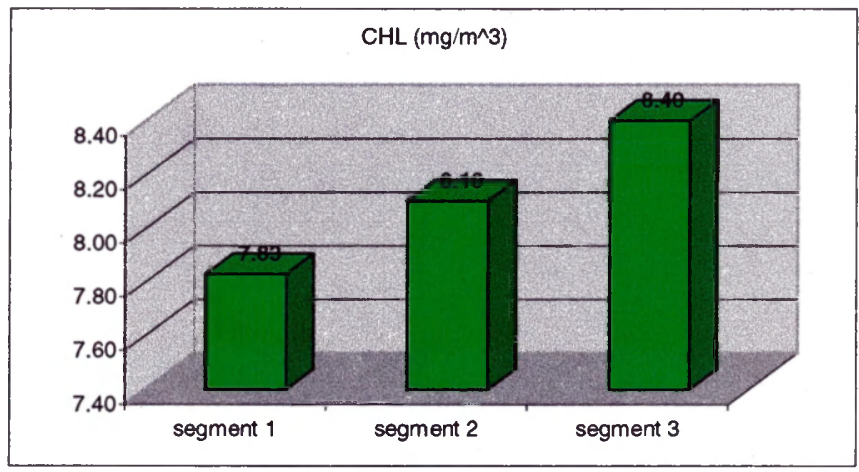

Figure 3-35. Chlorophyll "a" in March, Agriculture scenario (6 Years average)

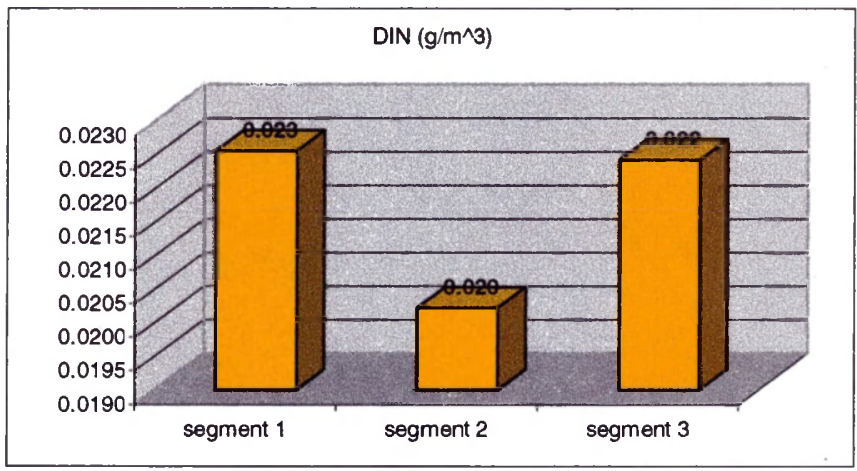

Figure 3-36. Nitrogen in March, Agriculture scenario (6 Years average) 


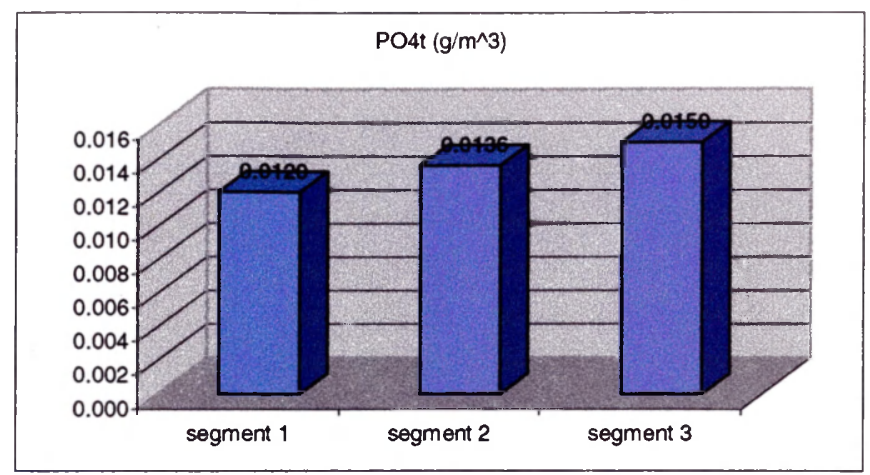

Figure 3-37. Phosphorus in March, Agriculture scenario (6 Years average)

Looking at nitrogen concentrations in Old Plantation Creek under the different development scenarios we find very little variation in the $1^{\text {st }}$ segment compared to the other two. It appears that further upstream, nitrogen concentrations better reflect relative nutrient loads from the land, compared to the loadings numbers (Figure 3-36). A similar situation was observed in the case of chlorophyll "a". 


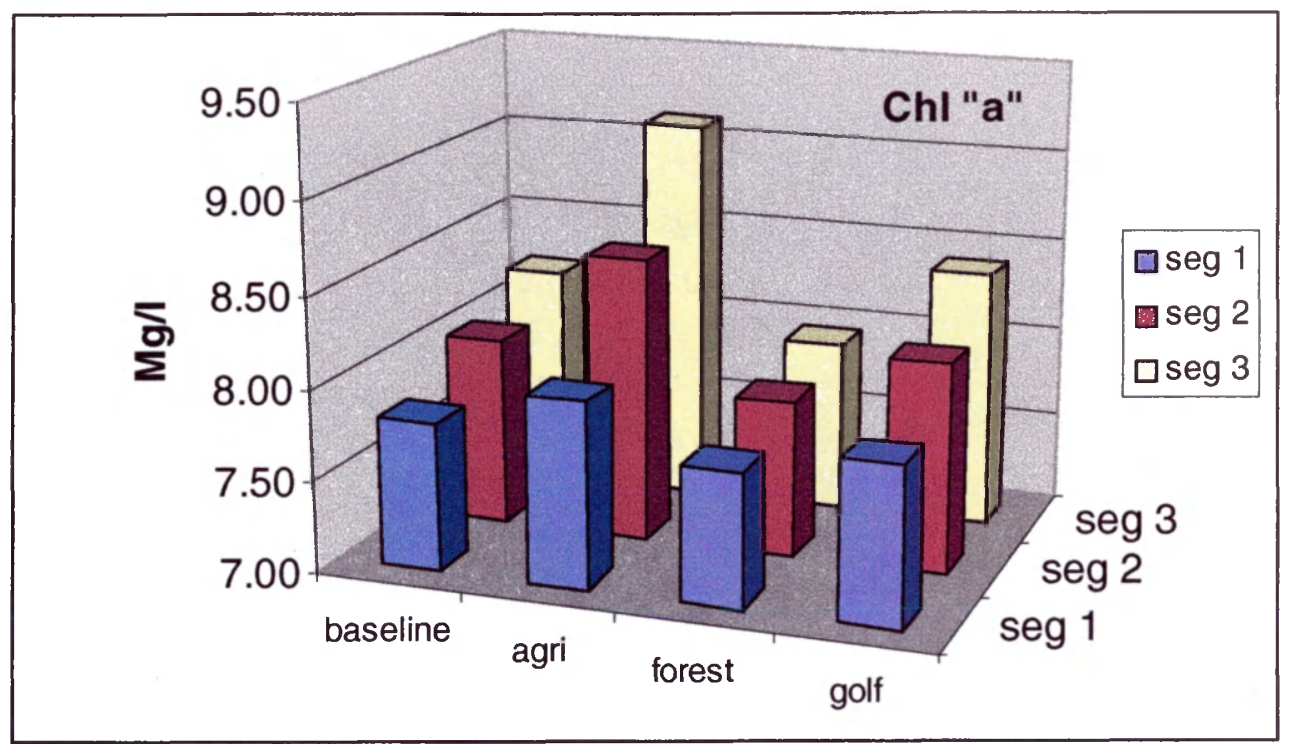

Figure 3-38. Chlorophyll "a" concentrations (Mg/l) in Water Column in the Lower, Middle and Upper Old Plantation Creek

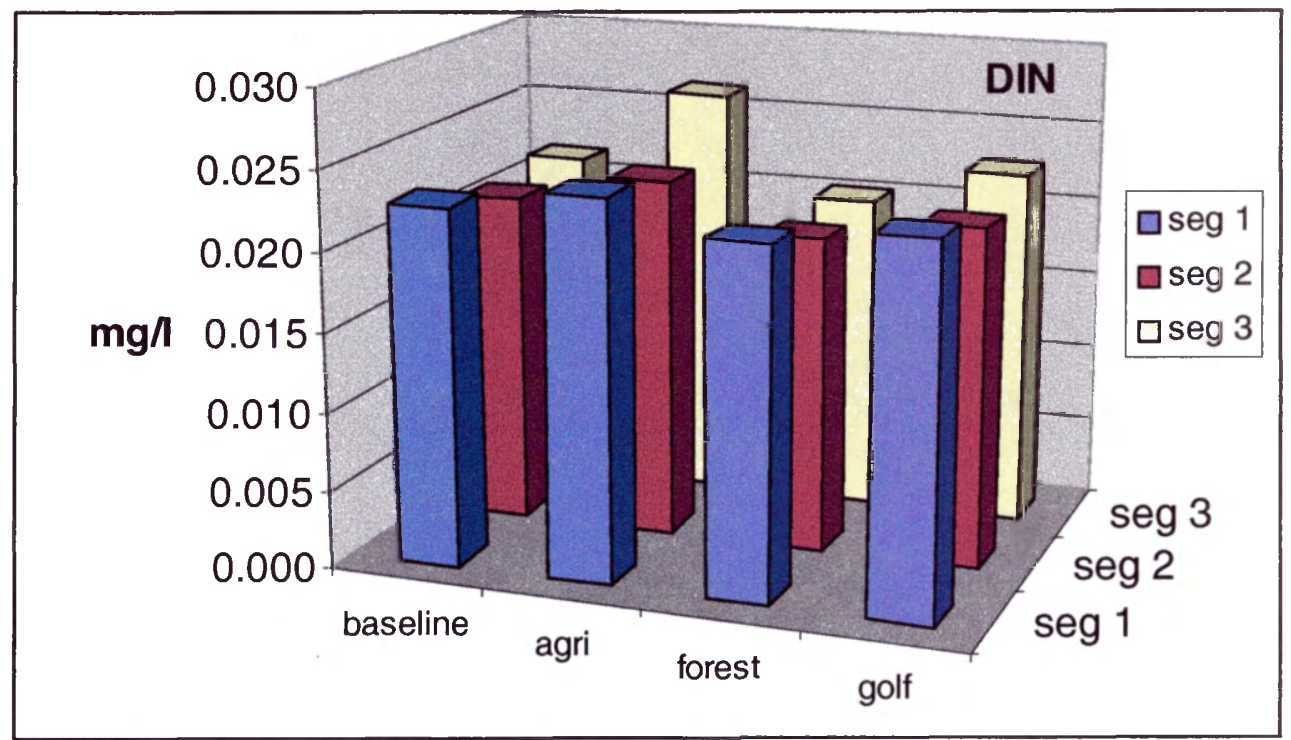

Figure 3-39. Nitrogen Concentrations ( $\mathrm{mg} / \mathrm{l})$ in Water Column in the Lower, Middle and Upper Old Plantation Creek 
With phosphorus, there is very little variation in the different scenarios in different segments. Unlike nitrogen and Chl "a", the highest amounts are seen in the $3^{\text {rd }}$ segment.

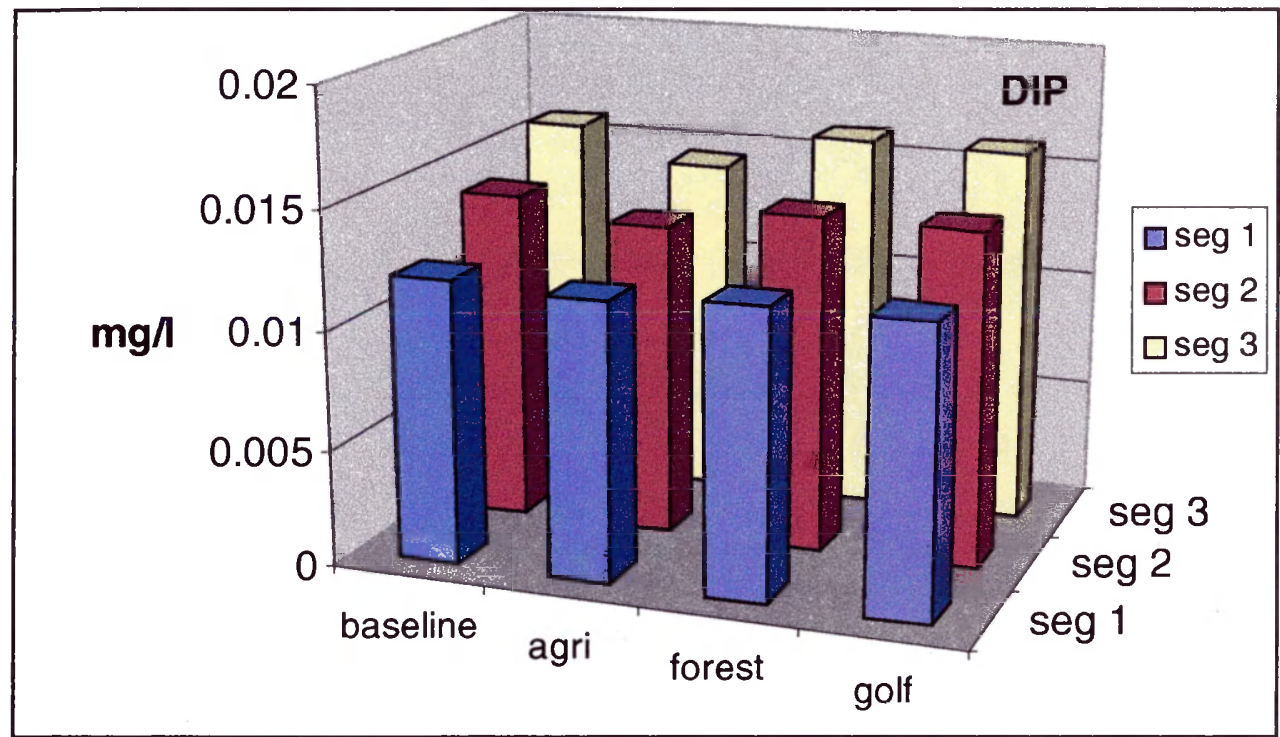

Figure 3-40. Phosphorus Concentrations (mg/l) in Water Column in the Lower, Middle and Upper creek 


\subsection{Discussion}

The objective of this part of the research was to determine the impact of development to water resources (SAV) of creeks adjacent to the development. There is a proposed development in what was earlier an agricultural parcel of land next to the town of Cape Charles, VA. Recently the town annexed the proposed development area. Developers will build two golf courses and a residential area for up to 3000 people. It is expected that the development will affect the surrounding Old Plantation and Kings creeks, where the runoff from land will end up. Until now there has been little conflict between land use and water quality of the creeks, though studies show that the water quality in Eastern Shore creeks is directly related to the land use patterns in adjacent areas. Robinson and Reay (1999) found that land use patterns were reflected in the water quality of ground waters in an area located to the north of Old Plantation Creek (Cherrystone inlet watershed). Average DIN concentrations underlying agricultural land, developed, and forested lands were $7.06,4.68$, and $0.77 \mathrm{mg} / \mathrm{L}$ respectively.

In this study, only Old Plantation Creek was studied as it is the creek where the greatest impacts from development are expected. Kings Creek watershed is not as large as Old Plantation Creek and it might be difficult to determine the effects of changing environment with the techniques used in this research. Also, part of the watershed of the proposed development is draining straightly into the Bay, which for the same reasons as King Creek was also not investigated. It would be more accurate to say that the impacts of development on Old Plantation Creek was determined, but the findings may be used/adapted for the areas not investigated, because the same general patterns of systems (soils, elevation, etc.) could be observed in those areas. 
In the first stage of the research BasinSim model was used for assessment of non point source pollution. That particular model was chosen because it is calibrated for Virginia watersheds, also it was an exercise to test a new technique for the small coastal basin. For example in previous studies Kuo et al. (1998) used the STORM model produced by the US Army Corps of Engineers for non point source pollution loads. After the study they concluded "a better non point source model than STORM should be used, and calibrated for basins with different land use characteristics". The loads were recalculated with the help of TPWQM. The latter model was chosen because of its ability to calculate pollutant concentrations in the water column and because it has been tested in the creeks of Virginia. TPWQM was designed to calculate point source pollutants concentrations in small creeks, but the model works for non point source pollution as well (A. Kuo, S. Kim pers. communication), if one assumes that the runoff from land is point source pollution. It was discovered later and also could have been predicted knowing the tidal peculiarities of the creeks in the Eastern Shore, that after several tidal cycles water and pollutants are well mixed in the creek and it is not so important if it is point or non point source pollution. Also taking into consideration that the TPWQM is run automatically 100 times before outputting information, we could expect that the influence of considering the pollution as point source instead of non point source is minimal (after 100 tidal cycles the water is mixed and diluted). The assumption is supported by the fact that tidal volume is almost equal to the volume of the creek or, in other words, with every tide half of the water in the creek is changing. 


\section{Concerns}

Pollutant loadings effects to the creek's water quality (nutrient loads in different scenarios vary by the order of three) are distributed in a much bigger area than the creek adjacent to the study watershed. Keeping in mind the dilution factor, we could predict that the assessment of the impacts of development will not show a significant deterioration of water quality. Pollutants are mixed and diluted in the water column and most likely it is the Chesapeake Bay that assimilates the excess nutrients. TPWQ model runs showed that even very high pollutant loads (for example if we take a nitrogen concentration in runoff of $10 \mathrm{mg} / \mathrm{l}$, when in the Baseline scenario nitrogen concentration was only $1 \mathrm{mg} / \mathrm{l}$ ) are not detrimental to water quality in the creek. Bearing that in mind we can say that we can tolerate the pollution because it is not significantly harming the local ecosystem. But in this case we could encounter a dilemma, such as smoke stacks and acid rains. For that reason we decided to look into the relative impacts of the pollution. We could do that while examining the concentrations in the water column (output from TPWQM), also the total loads from land (outputs from BasinSim). In the case of the first idea we and other scientists (Kuo et al., 1998) encountered one more issue which forces us to reevaluate the indicator capabilities of the methods in the case of the small creeks: research shows that the closer is segment to the Bay, the less variability is observed in different scenarios. The loading from the land may vary by a factor of two allowing us to see the difference at the head of the creek, but at the mouth the water quality values will be almost the same. For that reason this method can be used but the influence of larger water body from which tides are coming must be taken into consideration. So it seems that for the relative impacts assessment, total loading is a 
better indicator. In this work both methods were investigated. The hypothesis about the diversity in water quality in different parts of the creek was corrected by the fact of tidal flushing - water volume that is added with every tide dilutes and mixes pollutants in the creek. We might expect estuarine circulation in the creek, but field observations suggest that the creek is very shallow and most likely well mixed.

\section{Segmentation}

Given the geography of the creek (relatively long and narrow), the influence from the land (relative land use patterns in different parts of the watershed), and the fact of tidal flushing, it was expected that there would be variability in water quality in different parts of the creek. For that reason the creek was divided into segments. While segmenting the creek TPWQM calculates the volume (in each segment) of the creek. It was discovered that the input information that is required by the model is not comprehensive in the sense that the model takes only a few point in the creek from which the general geometry is automatically determined and the creek is divided into segments and the volume of the creek is determined. Examination of a bathymetric map of the creek shows that there are many tidal flats. The general depth of the creek is also not well presented in the sense that the depth shown in the map indicates the main channel depth. Taking into consideration that most of the creek is not in the main channel, one might argue that interpolating the volume of the creek would be incorrect. For that reason the volume of the creek was calculated from the Digital Elevation Map of the area. Our concerns were correct: the TPWQM with initial measurements overestimated the volume (the depth) of the creek by two million gallons. The whole volume of the creek 
in high tide is three million gallons. The input files were adjusted to match this volume. The watershed of the creek was also divided into segments to meet the segmentation of the creek. The segmentation revealed several important features of the creek described below.

\section{Groundwater}

The importance of the ground waters is emphasized in several works done on the Eastern Shore and in the Chesapeake Bay region. Robinson and Reay (1999), Robinson et al. (1998), Simmons and Reay (1990) stated that ground water is the dominant source of water to non-tidal stream flow in Chesapeake Bay coastal watersheds, and direct ground water discharge to its estuarine waters is significant. The other study (Richardson, 1992) showed that the Eastern Shore has an average annual rainfall of 43 inches $(109 \mathrm{~cm})$ of which an estimated 12 inches $(30 \mathrm{~cm})$ recharges the Columbia aquifer. The remainder is lost to run-off and evaporation. BasinSim model predicted that the main freshwater discharge form from the study watershed is groundwater (in some cases up to $100 \%$, APPENDIX A).

Moreover, the studies show that groundwater plays an important role in pollutants transport. Robinson and Reay (1999) found that subsurface losses generally represent between 75 and $95 \%$ of the total nitrogen runoff losses. Reay et al. (1992) study showed that coastal areas along the Chesapeake Bay have high potential for contaminated submarine ground water discharge (SGWD) due to elevated water table heights, highly permeable sandy soil and flat topographic features which reduce rain runoff potential. 
The other important fact about groundwater is that the residence time might be very long and the effects of the pollution might not be felt until decades later. Robinson and Reay (1999) reported that the average residence time of ground water within Eyreville Creek (Cherrystone Inlet) watershed was 20.6 years. Approximately $95 \%$ of the ground water resource would reflect land use activities within the past fifty years. Sooner or later the runoff from watersheds will reach creeks. At this point it might seem that land use does not have influence on the creek's water quality. The proposed irrigation system by the Bay Creek Developers where all runoff would not go directly to the creek, but to water retention ponds, may solve the problem of suspended solids, but not the nutrients ( $\mathrm{N}$ and $\mathrm{P}$ ) issue, which in dissolved form may travel through ground waters.

Robinson and Reay (1999) stated that if nitrate comprises greater than $90 \%$ of the inorganic nitrogen within shallow ground water, it means soils are characterized as well drained. According to the soil maps of the Eastern Shore in the research area the soils are from hydrologic group A, defined as highly permeable soils. Also our findings show that almost $90 \%$ of the nitrogen in the runoff was in dissolved form.

\section{Loads (BasinSim)}

The BasinSim model was tested with the observed stream flow data. The regression coefficient showed a significant relationship between predicted and observed values. As the stream flow is responsible for carrying the pollutants to the creeks we expect that the model will perform with the same accuracy regarding nutrients and suspended solids loads. 
It is known that what is coming from the land depends on the activities in the watershed. In our study the results showed that the highest nitrogen concentrations were observed in the Agriculture scenario, the lowest in Forest scenario. Forest is considered to be the most pristine among all scenarios. Nutrients are expected to be used by vegetation and also there is no fertilizer application. In the Agriculture scenario the loads are expected to approach the loadings of the whole watershed even though the proposed development area is only $1 / 4$ of the whole watershed. The Agriculture scenario would bring three times more nutrients to the creek than would the Baseline scenario. In the case of the Golf Course, the loads are not expected to increase as much as in Agriculture, even though application of fertilizer to a particular part of the watershed (grassland) is expected to be three times greater than in the Agriculture scenario. But in the case of the Golf course scenario it is expected that $1 / 3$ of the land will remain forested, which might be the reason for lower nitrogen loads. We could expect that with the diversity of land uses, the loads would not be as high as in monoculture land use.

In the case of phosphorus, comparing the Baseline scenario with the Whole watershed, the relative loads to the creek are similar to the ratio of the smaller watershed and the whole watershed (1/4). The largest P loads would be in the Golf Course scenario. It is different than nitrogen scenario; the Agriculture scenario would be contributing less that the Golf Course. The Golf Course scenario would be contributing almost $1 / 3$ compared to the Whole watershed. This might be related to the fact of higher phosphorus application to the Golf Course (three times more than in agricultural practices). Also, the residential area, which comprises $40 \%$ of the Golf Course scenario area, contributes 
more phosphorus because impervious surfaces comprise $20 \%$ of all surfaces and it is assumed that the runoff goes straight to the creek and does not penetrate into ground.

Fertilizer application to the fields and the area with application, vegetation and impervious surfaces all add up to difference in loads in the different scenarios. In the case of nutrients ( $\mathrm{N}$ and $\mathrm{P}$ ) in the Golf Course and Agriculture scenarios compared with the Baseline scenario, it is expected that the loads will increase and bring relatively more nutrients to the creek. This is related to the fact that the amount of fertilizers applied to the land increase in the Golf Course scenario and the area with fertilizer application increases in the Agriculture scenario. Also the impervious surfaces increase in the Golf course scenario. Forest area is replaced in those two scenarios.

Suspended solids movement in the system is determined by the different thickness and quality of vegetation cover, which varies through the year (e.g. forest vs. agriculture field). Suspended solids from the Forest scenario should contribute zero tons to the overall watershed, since it is expected that the vegetation cover prevent suspended solids from running off the land. In the Baseline scenario we found that solid loads are much higher (20 tons/year). The loads from the Golf Course are expected to be almost the same as in the Baseline scenario. The highest loads are expected to come from the Agriculture case. The reason for that might be that the BasinSim looks into the land cover through the year and in the case of Agriculture it is expected that during winter the land would be bare, without plants in agricultural areas. In the case of the Golf Course, the land would be covered with grasses through out the year.

Our study showed that almost $90 \%$ of the runoff waters reach the creek through ground waters, so we could expect that suspended solids runoff to the creek is not 
significant because of the permeable soils (filtration) in the watershed. But studies by Kuo et al. (1998) showed that total suspended solids (TSS) exceeding the requirements were observed in four (all of the studied basins) coastal basins of Virginia (Hungars Creek, Cherrystone Inlet, etc) and in all four seasons. One of the reasons for that might be coastal erosion. This matter needs further investigation.

While looking into the loads from each separate segment in different scenarios we can see that even though the segment might be larger in size it can bring less nutrients and suspended solids to the creek. This supports the hypothesis that loads are correlated with land use differences in different segments. For example the $1^{\text {st }}$ segment is the largest (331 ha). The other two segments are smaller $\left(2^{\text {nd }} 161\right.$ ha, $3^{\text {rd }} 150$ ha). But the largest loads are expected to come from the $2^{\text {nd }}$ segment. The $1^{\text {st }}$ segment has some wetlands and more forests. The segment influence will be important in analysis of the pollutant concentrations in the creek. It was expected that according to the loads in particular segments we could expect to find relative concentrations in adjacent creek segments.

\section{Concentrations in Runoff (BasinSim)}

In the previous chapter we examined nutrients and suspended solids loads from the watershed. Loads usually come to the creek with runoff, so it is important to know not only the quality but also the quantity of runoff. In other words, we want to know the concentration of nutrients in runoff, which is determined by freshwater inputs (precipitation). Each segment varies in land use, which influences nutrient loading. For example, in the agricultural area we expect more nutrients coming to the creek because of 
land use practices. By examining concentrations in the actual freshwater that is running from the land we are able to predict from which watershed/scenario the most nutrient laden runoff is expected. The results show that the most nutrients would come from the Agriculture scenario, followed by the Golf Course scenario. The Baseline scenario runoff would have a moderate amount of nutrients in runoff while the Forest scenario nutrients concentrations in runoff approach zero. This is very important in the next stage of the research where we investigate the concentrations and relationship of nutrients and phytoplankton (Chl "a"). While examining the seasonal loads of the pollutants we notice that the largest loads are expected to be in the spring (March). This matter was investigated while averaging the loads with the runoff volumes, which showed that the runoff water quality actually does not change much in spring $(\mathrm{N} \sim 0.5 \mathrm{mg} / \mathrm{l}, \mathrm{P} \sim 0.75 \mathrm{mg} / \mathrm{l}$ in the different scenarios), perhaps because the larger runoff dilutes the increased nutrient loads.

Concentrations in the Old Plantation Creek (TPWQM)

Pollutant concentrations in the creek might be helpful in assessing water quality if compared to known habitat suitability indexes of natural resources. In this study water quality was compared to habitat suitability indexes of submerged aquatic vegetation (SAV). Parameters measured were Chlorophyll "a" (Chl "a"), total dissolved nitrogen (DIN) and total dissolved phosphorus (DIP). These parameters are interrelated in the ecosystems. Nutrients are used by phytoplankton; if concentrations are low we could expect low Chl "a" concentrations in the creek. On the other hand, phytoplankton is regulating nutrient levels. 
Kuo et al. (1998) ran the TPWQ Model for the coastal creeks of the Eastern Shore in 1997. Their results show that there was essentially no instance of nutrient concentrations exceeding the SAV habitat requirements in Eastern Shore creeks. Our study confirms those facts. In our study we found that DIN, DIP and Chl "a" concentrations did not exceed SAV habitat requirements in the creek under the different development scenarios. That shows us that land use change will not have a significant impact on the water quality (based on SAV habitat suitability requirements) in any of the development scenarios, but some trends could be determined, e.g. when and where we could expect the most pollution, and the relationship between nutrients and phytoplankton.

In this study it was not possible to determine suspended solids concentrations in the creek. From our results we can see that the worst scenario would be Agriculture because we could expect the highest suspended solids loads and for management purposes we could suggest making this number as low as possible. Kuo et al. (1998) showed that total suspended solids (TSS) concentrations exceeding the requirements were observed in four (all studied basins) coastal basins of Virginia (Hungars Creek, Cherrystone Inlet, etc) and in all four seasons. Kuo et al. (1998) found that the TSS concentrations show either an increasing trend or no trend landward from different basin mouths. This suggests that local watershed runoff/or shoreline erosion contribute to the excessive TSS concentrations. These finding are partly consistent with current research (our) findings which show that in the middle segment of the creek solids loads are expected to be lower that in the more upstream watershed. But also our results show that 
larger loads are expected in the lower part of the creek (first segment). This might be related to segment size (segment 1: 300 ha, segment 2: 160 ha, segment 3:150 ha).

Yearly concentrations of Chl "a" will not exceed the SAV habitat suitability requirements. The $\mathrm{Chl}$ "a" concentration follows the nitrogen loads pattern. This shows that the relationship between $\mathrm{N}$ and algae growth is stronger than between $\mathrm{P}$ and algae (Chesapeake Bay Program. 1999). Also it is expected that in the Agriculture scenario the concentrations in the creek are expected to be as high as if we have runoff from the whole watershed. The scenarios are assumed to be loadings from the smaller watershed alone on the assumption that loading from the bigger watershed does not violate water quality.

Other research showed that we could expect that Chl "a" concentration exceed SAV Habitat Suitability Requirements. According to Kuo et al. (1998), most of the excessive Chl "a" concentrations were observed in late winter and early spring (February and April) in four Virginia coastal basins. No concentration exceeding the requirements was observed in fall and early winter. To test the hypothesis that the loads are higher in the springtime we performed an analysis for the March month alone. Spring concentrations showed that the water quality is changing going up the creek, but that the concentrations are not exceeding water quality requirements for SAV. The reason for that might be that in the spring months the most freshwater runoff occurs. Results also show that in the middle of the creek the nitrogen concentrations are lower than upstream and downstream. The reason for that could be the creek bathymetry: in the middle of the creek there are several deeper places where the water might stay longer and not be readily mixed with the incoming tide waters. As water stays longer in one place nutrients are used up by the phytoplankton. The above finding shows a mismatch of our data and 
findings of Kuo et al. (1998). The reason for that might be the techniques used (Kuo et al. use STORM) or the creek peculiarities. Further investigation is needed

There is not much empirical data for validation of the model. Monitoring in the creeks of the Eastern Shore has not previously been performed. Kuo et al. (1998) conducted some research in the creeks to the north of the Old Plantation Creek. Also some measurements were done in the creek in 1990 by Espey, Huston \& Associates, Inc. (Baseline Environmental.., 1990, Water Quality..., 1999). They found that the nitrogen (TKN) levels in the lower creek were $0.11 \mathrm{mg} / \mathrm{l}$ in April and $0.36 \mathrm{mg} / \mathrm{l}$ in June.

Phosphorus (TP) levels were accordingly 0.03 and $0.02 \mathrm{mg} / \mathrm{l}$ in April, and 0.15 and 0.8 in June. This is consistent with (our) findings: water quality is worse upstream and better downstream. Also the amount of nutrients is almost the same from the simulation and from the actual measurements (See APPENDIX C).

Results show that the more nitrogen input to the creek the more Chl "a" we could expect in the creek. This demonstrates that nitrogen is a limiting factor in the system. In this case it is possible that the loads from the Forest scenario are the lowest, but when it comes to concentrations in the water column, phosphorus reaches the highest concentrations (from all other scenarios) because it is not used up by phytoplankton, which are nitrogen- limited. For example in the Agriculture scenario there is a lot of nitrogen in the system as well as Chl "a" but, there is not so much phosphorus: it is used up by phytoplankton. In the Baseline scenario there is less nitrogen and $\mathrm{Chl}$ "a" but there is more phosphorus. In the case of Whole watershed there is a lot of nitrogen and there is a lot of phytoplankton (Chl "a") and phosphorus is used up. 
One more fact that explains these results was described earlier. This is the factor of dilution and tidal flushing. The volume of the creek and the volume of the tidal waters that are coming to the creek with every tide were almost equal (creek volume: $\sim 1.7$ million cubic meters, tidal volume: $\sim 1.8$ million cubic meters). The Bay water has a lot of influence on the water quality of the creek. Water quality is not degraded in the different parts of the creek because water coming from the Chesapeake Bay dilutes the pollutants. The runoff from the watershed might not be significant because it is only $\sim 10$ million gallons per day (MGD), while the whole volume of the creek in high tide is 700 MG. Several studies indicate that we should have expected that the influence of the Bay to the creek ecosystem is significant and in most of the cases it is the Bay that controls concentrations in the creek. On the other hand the Eastern Shore Coastal Basins Nutrient Reduction Strategy (1999) says that the water in the tidal portions of the local Eastern Shore creeks have little influence on the water quality of the Bay itself. Our research supports the hypothesis regarding the Bay. Incoming loads from the Old Plantation Creek are diluted by the tidal water and are not significant in the creek and probably not significant in the Bay because there is so much more water volume. Kuo et al. (1998) concludes that both model and field data indicate that the water quality in the lower portions of small basins is dominated by the conditions at the mouth in the Bay. The upper portions of the basins may be temporarily dominated by non point source loadings during and immediately following runoff events.

In sum, the results how that water quality in the creek is not exceeding the SAV habitat suitability indexes in any of the proposed scenarios. Also we can conclude that the highest concentrations of pollutants are expected to be in the Agriculture scenario, 
lowest in the Forest scenario. In the Golf Course scenario, the concentrations are expected to be slightly higher than in the Baseline scenario.

\subsection{Future research}

High nutrient levels are not always harmful for the environment. Nutrients might have a positive influence on chlorophyll "a" (phytoplankton) concentrations, which in turn positively influence clams that are extensively grown in the Old Plantation Creek. The other question not answered in this study: how much water quality in the creek is influenced by the filtration of the shellfish beds? Some studies show that clams might have a significant effect (Mark Luckenbach 2001, pers. communication).

Fecal coliform bacteria may jeopardize the well-being of the clam beds. If the levels exceed the threshold determined by Department of Environmental Quality, shellfish beds will be closed. In the Eastern Shore the study by Schima (1993) showed that groundwater transport could not be statistically linked to high bacteria counts in the

creeks. As our and other studies show, most of the waters come to the creek from ground waters, thus we could expect that fecal colliform bacteria levels would stay stable through time.

Luckenbach et al. (1996) reported that water quality in the Eastern Shore creeks may be generally good but storm events can cause environmental degradation. The only discernable trend of water quality in the Eastern Shore is in total suspended solids, which are increasing and generally tied to runoff from land uses in a particular watershed (Luckenbach et al. 1996). These findings are consistent with our findings that, in general, water quality is not degraded. 
Predicted nutrient concentrations will not exceed the habitat suitability index of SAV. But there are other concerns not investigated in this study: the peaks of nutrient and sediment flushing in particular parts of the year (spring), which might be vital in the life cycle of aquatic organisms. Several studies have dealt with SAV survival in the Chesapeake Bay region and worldwide. They revealed that, in some cases, it may be the peak rather than the long-term average concentrations of nutrients that determines the stress level experienced by seagrass (e.g. Zostera marina). Although the mechanism is not understood, it is hypothesized that chronic water column nitrate enrichment may promote internal nutrient imbalances that lead to plant death (Moore et al. 1996, Moore et al., 1997). Further, extended periods when community respiration exceeds production may have important implications for seagrass survival. Although seagrasses such as eelgrass appear well adapted for survival in anaerobic sediment environments, periods of sediment hypoxia have been associated with the decline of seagrass species in other regions. Increased sediment sulfide levels, which are associated with sediment anoxia in marine seas, have been related to depressed photosynthetic potential (a measure of a macrophyte's ability to maximize the use of available light) in eelgrass. Depressed photosynthetic potential may result in loss of vegetation in stressed environments. Relatively short-term stressful conditions, especially during certain critical periods, can have long-term consequences for these plants even after conditions have improved. Therefore, studies investigating the causes of seagrass decline need to look at the impacts of pulsed and extreme events in addition to changes in average conditions to determine the factors limiting seagrass survival. (Orth and Moore, 1984, Dennison et al., 1993) 
While looking into the environmental problems we had to take into account the relationship of the watershed with the research area. Similarly study of the socioeconomic aspects of development between sections of this study requires a view from the perspective of the whole county. This might induce some discrepancies regarding geographical area, but once again confirms that we cannot place boundaries on environmental issues. 


\section{SOCIOECONOMIC INDICATORS}

\subsection{Introduction}

The many uses of a given resource will each yield a benefit to some segment of population. Though they need not be consumptive, damaging, or in conflict with each other, any foregone benefits from conflicting uses impose costs on others in society (Beekman et al., 1997). That is why in Sustainable Development Action Strategy the Northampton community decided that: "The true measures of success must come in the enhancement of the community's economic, social and environmental health. Specific indicators to be tracked in each of these areas include: economic, social and environmental indicators" (Northampton County Board..., 1994).

This chapter deals with socioeconomic indicators. Population growth, employment and income dynamics are analyzed. A smaller portion of Northampton County, for example the town of Cape Charles could have been chosen as the economic unit, but because of data limitation and the impact that the selected development will have on the region it was decided to investigate the whole county. The historic information was extrapolated into the future in order to see what would happen under different development scenarios.

Recently rural retirement counties have started to fill the area between metropolitan counties along the East Coast of the United States. A retirement county is 
one with greater than $15 \%$ in-migration of people 60 years or older during the preceding decade. In these counties, the in-migration of the elderly prevents a relative population decline, but the migration certainly changes the counties' age distribution (Shabman L., 1997). Eastern Shore, VA remains undeveloped because of the limited access and distance that separates the region from big development centers. Recent development proposals show that the in-migration scenario might happen to the Eastern Shore as it has to the rest of the East Coast. The proposed Bay Creek Development in Cape Charles area is a good example.

The biggest industries on the Eastern Shore are chicken farming and tomato growing. Recently shellfish (hard clam) aquaculture has become the third largest industry (Eastern Shore of Virginia Economic Development Commission. 2001). The largest private employers on the Shore are Perdue Farms (1,900 employees) and Tyson Foods (1,000 employees), both of which operate chicken processing plants and are located in Accomack County. Eastern Shore of Virginia provides good incentives for development, for example, general income tax credit; i.e. ten years of credits against the Virginia income tax $(80 \%$ reduction of 1 st year's tax, and $60 \%$ reduction in years 2 through 10) and recycling equipment tax credit; i. e. an income tax credit available to manufacturers for the purchase of certified machinery and equipment for processing recyclable materials (Eastern Shore of Virginia Economic Development Commission. 2001). In addition, Virginia Industrial Access Road Program grants funds to assist in constructing industrial access roads to new and expanding manufacturing or processing companies (Eastern Shore of Virginia Economic Development Commission. 2001). Despite these advantages Northampton County is showing poor economic results. 


\section{Northampton County Overview}

Northampton County is located at the southern tip of the Delmarva Peninsula and occupies the southern half of Virginia's Eastern Shore. A thin landmass separating the Atlantic Ocean and Chesapeake Bay, 225 miles of shoreline enclose some 134,000 acres of prime cropland, saltmarsh and forest. The Chesapeake Bay Bridge-Tunnel, its sole physical connection with the Virginia mainland, is a dramatic seventeen-mile span. Open landscapes and a pastoral atmosphere persist today- a small but distinct interruption in the East Coast's solid line of seashore development. Founded in 1620, the County was one of the eight original shires of colonial Virginia. Today it is home to the oldest continuous court records in the United States, as well as a wealth of history, historic and archaeological sites, early buildings and artifacts (Northampton County Board..., 1994).

\section{Development Urgency}

Despite prime cropland, saltmarsh and forests, Northampton has severe problems. The County is the most impoverished of the 136 counties in the Commonwealth of Virginia, with a declining population and steep job losses resulting from reversals in its dominant seafood and agricultural industries. According to the 1990 census, twenty seven percent of the County's 13,000 inhabitants live in poverty compared with ten percent statewide. Much of the poverty is concentrated in the African-American population, which constitutes forty-seven percent of the total population. Sixty-four percent of families with female heads of households and children under age 18 live below the 
poverty level. This number increases to seventy percent in households with children under five years of age (Northampton County Board..., 1994).

Large numbers of the population are unemployed, underemployed, or working for minimum wage in part time jobs. According to the census, $30 \%$ of the residents earn less than $\$ 10,000$ and half of those residents have annual incomes of less than $\$ 5,000$. Unemployment in 1991 measured $9.4 \%$ compared to $5.8 \%$ statewide. Many of Northampton's residents have only seasonal employment. More than 1500 jobs have been lost during the past five years due to seafood and vegetable processing plants closing, manual farm labor disappearing, and seafood not replenishing to the degree that is necessary for substantial harvesting. In fact, total employment dropped six percent from the third quarter of 1988 to the third quarter of 1992. Total wages (in 1992 dollars) dropped eleven percent during the same 1988 to 1992 period (Northampton County Board..., 1994). Twelve percent of housing units lack indoor plumbing and eightpercent lack complete kitchen facilities. At least nine percent of homes do not have a central heating system and ten percent do not have indoor toilet facilities. Over thirty percent of the County's housing stock was built prior to 1940. As there are almost no affordable rental units that meet minimal standards of safety, families are forced to rent from slum landlords whose units are substandard and lack indoor plumbing. Many houses have started to collapse due to age and neglect, so that an already insufficient housing stock is continually shrinking. Many former dwellings stand empty and quickly deteriorate because absentee heirs cannot reach agreement as to the disposition of the property. Forty-two percent of the renter population pays thirty-five percent or more of its income for housing. Due to the lack of housing, every available dwelling is full or 
overcrowded. It is not unusual to find two or three families sharing a three- or four-room house.

Perhaps the most revealing economic composite of Northampton County is the $20.5 \%$ of Northampton County residents over 25 who have less than a ninth-grade education, compared to $11.2 \%$ in the State. Further, only $10.1 \%$ of Eastern Shore residents have obtained bachelor, or higher degrees compared with $24.5 \%$ for the State. The low educational attainment of the County's work force further limits industrial development. Northampton County continues to see out migration (decreased population for the past three censuses) and a rising level of unemployment (Northampton County Board..., 1994). Some comparative statistics of Northampton County and Commonwealth of Virginia are presented in the Table 4-1. 
Table 4-1. County and State economic and social statistics comparison

(Source: U.S. Census Bureau: State and County Quick Facts at http://quickfacts.census.gov/qfd/states/51/51131.html)

\begin{tabular}{|lll|}
\hline People Quick Facts & \multicolumn{2}{l|}{ Northampton County } \\
& $0.20 \%$ & $14.40 \%$ \\
Population, percent change, 1990 to 2000 & $53.30 \%$ & $72.30 \%$ \\
White persons, percent, 2000 (a) & $43.00 \%$ & $19.60 \%$ \\
Black or African American persons, percent, 2000 (a) & $65.70 \%$ & $66.30 \%$ \\
Homeownership rate, 1990 & 2.52 & 2.61 \\
Persons per household, 1990 & $26.90 \%$ & $\$ 40,209$ \\
Median household money income, 1997 model-based estimate & $\$ 22,912$ & $11.60 \%$ \\
Persons below poverty, percent, 1997 model-based estimate & $26.00 \%$ \\
Children below poverty, percent, 1997 model-based estimate & $37.90 \%$ & $17.00 \%$ \\
\hline Business Quick Facts & & \\
& Northampton County & Virginia \\
Private nonfarm employment, percent change 1990-1998 & $-7.00 \%$ & $16.30 \%$ \\
Retail sales per capita, 1997 & $\$ 55,716$ & $\$ 9,293$ \\
Housing units authorized by building permits, 1999 & 114 & 53,151 \\
Federal funds and grants, 1999 (\$1000) & 128,640 & $57,842,231$ \\
Local government employment - full-time equivalent, 1997 & 736 & 253,219 \\
\hline Geography Quick Facts & & \\
& Northampton County & Virginia \\
Land area, 2000 (square miles) & 207 & 39,594 \\
Persons per square mile, 2000 & 63.3 & 178.8 \\
\hline
\end{tabular}

\section{Development Potential}

In the Northampton County Sustainable Development Action Strategy (1994) the community has targeted several existing industries with immediate and ongoing potential to provide more and better jobs, income and revenue. These industries can be sustained indefinitely if developed and managed wisely. These target industries included agriculture, seafood/aquaculture, heritage tourism, arts/crafts/local products, research/education, value-added produce/seafood, and new industry (Northampton County Board..., 1994). 
Agriculture

Today, agriculture is the largest component of Northampton County's economy. With total industrial output exceeding $\$ 68$ million annually, the sector drives the rest of the local economy. According to a 1993 analysis by the Virginia Polytechnic Institute \& State University, agriculture supports more than 450 full time jobs in Northampton County and provides a net fiscal benefit (taxes minus cost of services) exceeding $\$ 400,000$ annually (Northampton County Board..., 1994). The same study indicated that the level of industrial output can be maintained and that the number of agriculture jobs can be doubled while producing the current mix of crops and using alternative, low-input agricultural practices. Chemical-free "organic" produce presents market opportunities for Northampton County (Northampton County Board..., 1994).

\section{Seafood and Aquaculture}

Throughout the County's history, watermen have harvested ample quantities of fin and shellfish from Northampton's bayside and seaside waters. For nearly 400 years, seafood, along with agriculture, has supported the local economy. In recent years, the Northampton County seafood industry (excluding aquaculture) has generated approximately $\$ 6.8$ million in income annually and supported 478 jobs (Northampton County Board..., 1994).

Since the late 1980's, aquaculture has come to play a very significant role in Northampton's economy. Northampton County's Cherrystone Aquafarms is one of the largest clam producers in North America with an annual harvest approaching 50 million clams and valued at over $\$ 7$ million. There are other successful clam hatcheries in the 
County as well as some soft shell crabbing operations. Aquaculture currently supports approximately 95 full- and part-time jobs in Northampton County and its economic impact is estimated at $\$ 10.5$ million. Currently, Northampton's aquaculture industry is built on a thriving hard clam market (Northampton County Board..., 1994).

\section{Heritage Tourism}

Heritage Tourism is defined as recreational travel activities, which depend on the appreciation, interpretation and protection of the community's authentic natural, scenic, recreational, historical and cultural assets. The heritage tourism industry in Northampton County is a significant component of Northampton's economy. People engaged in recreation, travel, and tourism in the county spent a total of $\$ 9.9$ million on lodging, restaurants, retail groceries, fuel and oil, and other goods and services in 1992. This initial spending generated $\$ 14,297,200$ in direct, indirect, and induced economic impacts and supported 454 jobs (Northampton County Board..., 1994).

There were an estimated 70,300 recreation party-trips in Northampton County in 1992 for fishing, boating, sightseeing, observing wildlife, visiting historic sites and other travel activities. These parties spent an average of \$203 in Northampton County (Northampton County Board..., 1994).

Fishing and boating on the Bay are the primary attractions for tourists and recreationists visiting the county. The First Annual Eastern Shore Birding Festival, held in October 1993 during the peak of fall migration, demonstrated the potential of birding to the County. Bird-watching tourists brought $\$ 52,000$ into the County during the twoday event, the equivalent of nearly two full-time, permanent jobs. Northampton County is 
known for its place in the annual Historic Garden Tour that is held each April (Northampton County Board..., 1994).

Given the cultural and natural resources found in Northampton County, it is likely that the county can attract a much larger share of the east coast tourism market. Demand for nature-based and heritage-based tourism outlets is great. According to a U.S. Fish and Wildlife Service study, over 3 million people in Maryland, Virginia and Pennsylvania reported traveling for the purpose of observing, feeding, or photographing fish and wildlife in 1991. In pursuit of these activities, residents of these three states spent over $\$ 819$ million on food, lodging, transportation and other trip-related expenses, and $\$ 952$ million on equipment (Northampton County Board..., 1994).

\section{Research and Education}

Research and education activities currently bring significant new dollars into Northampton County. Total known research expenditures in the county in 1992 amounted to about $\$ 377,500$ and supported 25 local jobs. These expenditures generated $\$ 691,200$ in direct, indirect, and induced economic impacts. In 1992, there were seven reported research groups active in the county spending over 5,900 research days. However, research and education activities in Northampton County have the potential to be significantly expanded beyond current levels (Northampton County Board..., 1994).

Northampton County is an ideal location for specialized research requiring the presence of relatively unspoiled coastal natural and cultural systems which are becoming increasingly rare throughout the world (Northampton County Board..., 1994). 


\section{Value-added Produce}

A recent analysis by Virginia Polytechnic Institute and State University of the economic potential of targeted industries in Northampton County indicated that the local agriculture and seafood/aquaculture industries could support development of a valueadded produce/seafood industry with an estimated potential of more than $\$ 20$ million in gross regional product and more than 500 jobs. The growing number of health-conscious American consumers and the growing demand for fresh produce and seafood, specialty products and chemical-free products grown in clean waters and "organic" soils present significant market opportunities for Northampton County (Northampton County Board..., 1994).

\section{Cape Charles Area Development}

Within Northampton County the Bay Creek development is expected to have significant impacts on the fiscal conditions of both the Town of Cape Charles and Northampton County, and on the economic conditions in the region. Some of these projections are described below (Table 4-2). 
Table 4-2. Predicted growth in Cape Charles and Northampton County due to Bay Creek

Development

(Source: Accowmacke Plantation, Fiscal and Economic Impacts Highlights, 1993 Cost benefit analysis study by consulting firm)

\begin{tabular}{|l|l|l|l|l|}
\hline & 1996 & 2000 & 2005 & 2010 \\
\hline Incremental Resident Retail Spending & 229,079 & 3970935 & 15,524322 & $37,240,761$ \\
\hline Incremental Tourist Spending & 665,916 & $3,597,163$ & $10,716,303$ & $21,645,611$ \\
\hline $\begin{array}{l}\text { Incremental positions for permanent } \\
\text { employment (construction jobs not included) }\end{array}$ & 34 & 351 & 1220 & 2,797 \\
\hline Construction jobs & 293 & 269 & 300 & 462 \\
\hline $\begin{array}{l}\text { Real and Personal Property Tax Revenues: } \\
\text { Estimates for town of Cape Charles }\end{array}$ & 147,635 & 415,644 & $1,020,046$ & $2,468,570$ \\
\hline $\begin{array}{l}\text { Real and Personal Property Tax Revenues: } \\
\text { Estimates for Northampton County }\end{array}$ & 382,459 & $1,103,535$ & $2,728,003$ & $6,592,269$ \\
\hline
\end{tabular}




\subsection{Methods}

\section{Forecasting}

Following the environmental section of the study different development scenarios were examined regarding social and economic changes under each of them. In order to predict what would happen in the future under different scenarios, forecasting techniques were used. First, historic trends of several socioeconomic parameters were examined and several indicators were chosen, among them: population, income, employment and property taxes.

Systematic, quantitative forecasting can help coastal zone management programs. Most forecasting is still judgmental and intuitive. People must integrate information from a large variety of sources, qualitative and quantitative, and this is probably best done by using the extraordinary pattern of recognition capabilities of the human brain (Stellwagen and Goodrich, 1997). The main advantage of statistical forecasting is that it separates the process of forecasting from that of goal setting, and makes it systematic and objective. The future is uncertain and this uncertainty must be represented quantitatively. Statistical forecasting represents uncertainty as a probability distribution. Two kinds of information are needed to describe the distribution: the point forecast and the forecast interval (or confidence interval) (Stellwagen and Goodrich, 1997). 
A point forecast is the median value of the distribution of future values, and can be thought of as a best estimate of the future value. Its forecast interval describes the spread of the distribution above and below the point forecast (Stellwagen and Goodrich, 1997). The upper confidence limit is often calibrated to the ninety-fifth percentile. This means that the actual value should fall at or below the upper confidence limit about $95 \%$ of the time. Forecasting methodologies forecast the future by fitting quantitative models to statistical patterns from the past. The forecast accuracy depends on the degree to which the statistical model can detect and extract statistical patterns from the historic data. The stronger these patterns are, compared to background irregularity, the more accurate is the forecast (Stellwagen and Goodrich, 1997). Univariate methodologies are based solely on the history of the variable we are forecasting. The most popular univariate techniques are moving average, exponential smoothing. Multivariate techniques relate the forecast to explanatory variables like demographic or macroeconomic indicators. The most widely used multivariate technique is dynamic regression (Stellwagen and Goodrich, 1997; Hibon and Makridakis, 1999) found that the rankings produced by various methods vary according to the accuracy measure being used. The performance of the various methods depends upon the length of the forecasting horizon. The performance of the various methods also depends upon the type (yearly, quarterly, monthly, others) of the data and the category (micro, industry, macro, finance, demographic, other) of the data. Statistically sophisticated or complex methods do not necessarily produce more accurate forecasts than simpler ones.

These five steps were followed in regression forecast (according to Roy Pearson, 2000, pers. communication) 
1) A specific plan of action was developed

2) Data were examined before regression

3) First regression runs were performed - just an exploration

4) Second set of regression runs - got models we can live with

5) Final models were selected

\section{Forecasts evaluation}

The parameters of a statistical model are estimated by fitting the model to a historic data set. Generally, this is done by finding the parameter values that minimize the sum of the squared fitted errors. The parameters were thus adapted to the sample data, and reflected any of its peculiarities. They explain the sample data better than any other parameter values, but they may not generalize well to out-of-sample data.

As a result, confidence limits based upon goodness of fit to the sample data are often too narrow. Out-of-sample testing can give a more accurate picture of actual forecasting performance. It can also help identify the model that performs best (p. 61).

\section{Testing the forecast model}

While using the Forecast Pro out-of-sample evaluator, we define a hold out sample for our data set and fit the model. Forecast Pro automatically calculates out-ofsample measures of accuracy for each possible forecast horizon. These include the Mean Absolute Percent Error (MAPE), the Mean Absolute Deviation (MAD), and the Geometric Mean Relative Absolute Error (GMRAE). The mean absolute deviation is also called the Mean absolute Error. The number of terms used in the average is $\mathrm{N}$, the 
sample size for forecast horizon $\mathrm{H}$. The MAD can be validly computed for any data with an interval scale. However, one cannot usually meaningfully compare the MAD from one variable with that from another, since its value is proportional to the scale of the variable. The MAD is most useful for comparing two forecast methods for the same variable. The MAPE is computed by dividing the forecast errors by the actual, taking absolute values and averaging. Thus the MAPEs for different variables are usually comparable. However, the MAPE is valid only for ratio scale data, i.e. positive data with a meaningful zero.

The final comparison statistic, the GMRAE is calculated using the relative error between the naïve model and the currently selected model. (Forecast from the naïve model equals the last historical data point.) A GMRAE of 0.67 indicates that the size of the current model's error is only $67 \%$ of the size of the error generated using the naïve model for the same data set.

By measuring relative errors, the GMRAE avoids some of the scaling problems associated with the MAD and MAPE. It is a good statistic to use when averaging measurements across series.

The column marked Cumulative lists the cumulative averages of MAD, MAPE and GMRAE up to and including the current horizon. In the example shown above, the cumulative MAD, MAPE and GMRAE for $\mathrm{H}=12$ involve a sample of 78 forecasts, ranging from horizon 1 to horizon 12 . 
Profiles of the Counties used for the analysis of Agriculture and Forest scenarios

In order to get better understanding of economic processes and trends under different development scenarios several counties were selected from Virginia. The selection was performed using a land use map of Virginia's counties. For the Agricultural scenario, Clarke and Loudon counties were initially selected. Later it was decided to eliminate Loudon county because the county is located near Washington DC and very likely the economic growth is influenced by the proximity of the Nation's capital. Also the number of people $(140,000)$ living in the county indicated that it is not likely that Northampton County would ever reach such a large population. For the Forest scenario, five counties were initially selected: Bath, Craig, Botetourt, Buchanan and Dickenson. It was decided to eliminate Botetourt and Buchanan counties in the further analysis, as their population numbers were three times larger than Northampton County. A description of each selected county follows:

The hallmark of government in Clarke County is the effort to conserve the county's agricultural character. Keeping land for agriculture is key to maintaining its important role in the local economy as well as preserving the natural character the county has enjoyed since its inception (Clark County. 2000).

Bath County offers some of the finest scenery and outdoor recreational opportunities in Virginia, is home to a world-renowned resort, and is populated by villages that exist today much as they did 30 years ago (Hodges R. 2001). Formed in 1790 , present-day Bath County has a total population of approximately 4500 . It is 90 percent wooded, and the George Washington National Forest encompasses over 250 square miles of its woodland and river valleys. The county also boasts the 2530 -acre 
Lake Moomaw, surrounded by undeveloped State forests and a source of mountain streams. It was its famous thermal springs, however, that first brought Europeans to settle the Bath County area over 200 years ago (Hodges R. 2001).

Craig County is located on the border of West Virginia and Virginia. The George Washington - Jefferson National Forest's natural beauty beckons people to Craig County. The region features many sites and activities for those who enjoy the outdoors. National Forest lands contain two wilderness areas and are home to an abundance of wildlife. Agriculture is the principle industry of Craig County. Twenty-four percent of the county is farmland (Craig County. 2001).

Dickenson County was formed in 1880 . The rough mountainous terrain influenced development of the area. Early settlers located along the streambeds where the best farmland was to be founded (Dickenson County, 2001). With the completion of the railroad, lumber and coal companies which had purchased mineral rights during the late 1800's moved in and began to develop their rich holdings. Between 1910 and 1920 , Dickenson County's population increased 47.2 percent as people moved in to work for the new coal mining and lumber companies. The county continued to grow until the 1950's at which time the mining companies began to incorporate automation into the mining process. Also, the lumber companies exhausted the timber supply and ceased operations. The resulting loss of jobs in these two major industries forced many people to leave Dickenson County. As the coal industry continued to decline during the 1960's, Dickenson County's population continued to decrease (Dickenson County, 2001).

Selected county's populations profiles are presented in Figures 4-1 and 4-2. Because of population numbers, some counties were not used in further analysis. For 
example Loudon County is located near Washington DC and its economy is positively influenced by the metropolis. In other counties, the population was too high (Buchanan and Botetourt Counties)

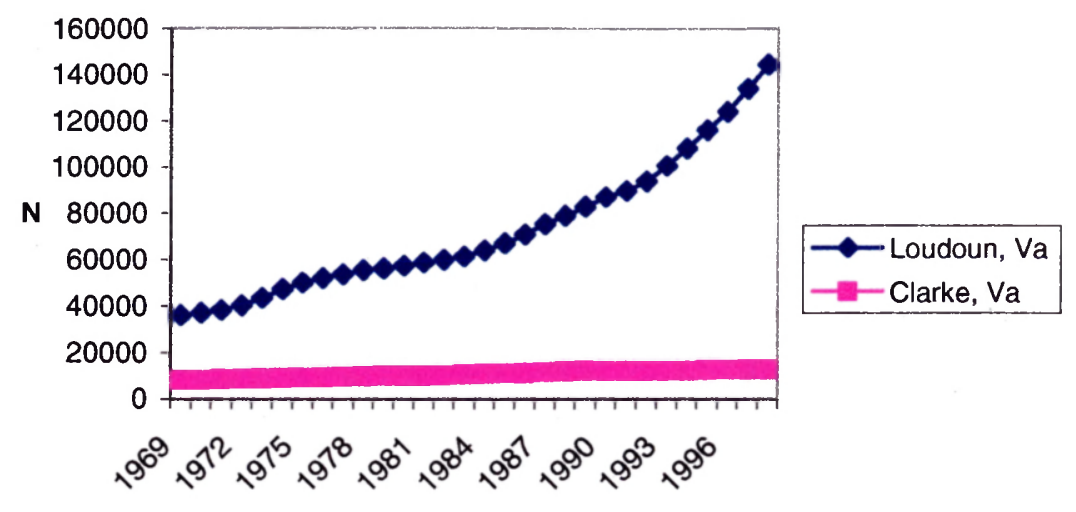

Figure 4-1. Counties with Agricultural Profile of Development (population N)

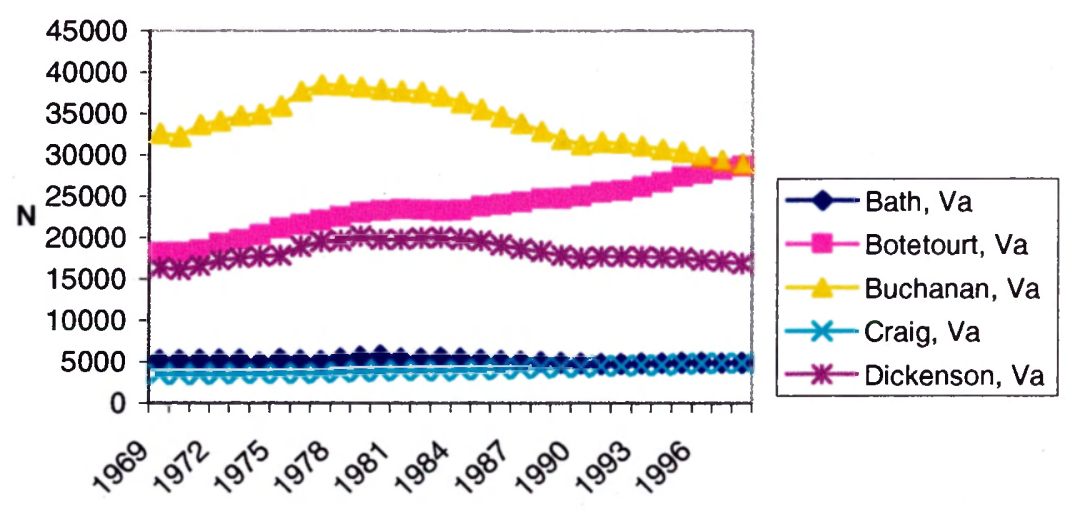

Figure 4-2. Counties with Forest Profile of Development (population N) 


\subsection{Socioeconomic Results}

\section{Baseline Scenario, Population}

Population is a controversial indicator, but change in the number of people in a particular area is very informative. For example if population is increasing we can say that people are satisfied and can afford to have more children. The increase might also reflect the in-migration of people who will be working in the area. In the case of the Eastern Shore it is most likely that in-migration might be induced by retired people looking for a pleasant and peaceful place to live. If people do not find those amenities or employment to their liking they have less children, they are moving to a different place and population declines. That is occurring today in Northampton County. Growth of population sometimes can be attributed to poverty, when people have more children in order to have someone to take care of them and to work in their agriculture fields when they get older, but such a trend is most likely to be found in developing countries; the social security system in most cases eliminates this need in the U.S.

The population of Northampton County has declined since 1978 (Fig. 4-3). Before that it was fluctuating around 15,000 people. According to the forecast the population decline might be expected to continue in the future if nothing changes in the county (the forecast was performed using Holt's Exponential Smoothing technique. The validation of the forecast is presented in the APPENDIX 4). The decline might be 
attributed to the changes in local seafood and agricultural industries: there was a steep decline in employment in two last decades. Other changes were more specific to localities: Cape Charles town lost its significance as a port after the construction of the Chesapeake Bay Bridge Tunnel in 1964 and the military base at the southern tip of Delmarva peninsular which was a home for several hundred families was vacated in the $1980 \mathrm{~s}$.

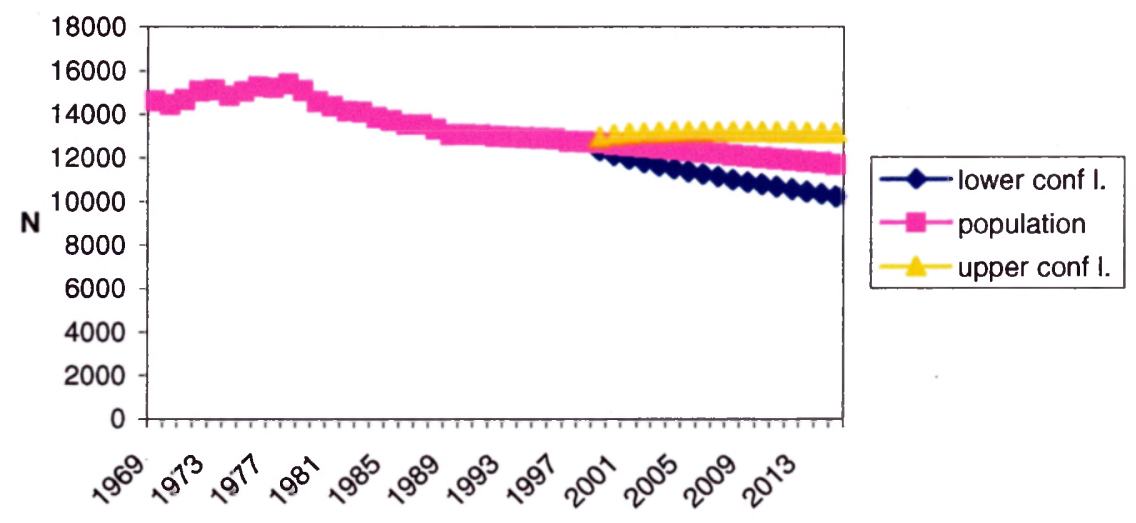

Figure 4-3. Baseline Scenario Population, Historic and Projected Number of People

The suitability of the model was performed by use of the common forecast coefficients (Durbin Watson, Ljung Box statistics, correlation coefficient). Also the performance of the model was tested while forecasting historic data (Fig. 4-4) and comparing with known history.

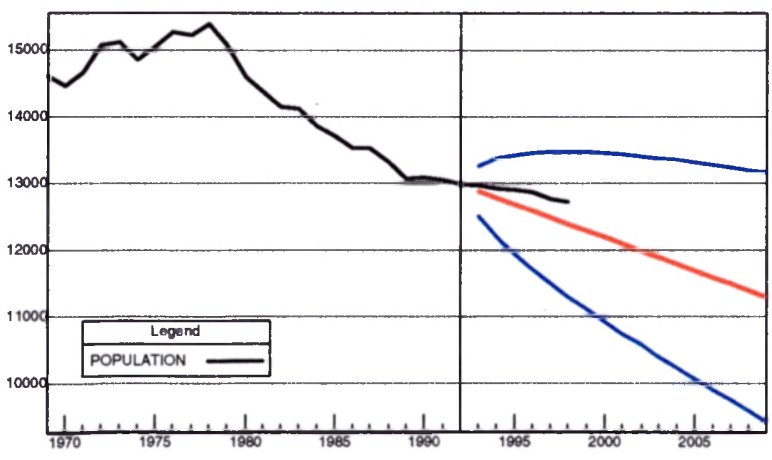

Figure 4-4. Population

forecast and historic data

comparison with the forecast

by holding out 6 history years

(forecast - red line, historic data- black line, confidence intervals - blue line). 


\section{Baseline Scenario, Employment}

Employment in Northampton County was following the population pattern until the beginning of the 1990 s, with a tendency to increase until the beginning of the eighties. At that point the employment numbers started to go down but picked up at the beginning of nineties (Fig. 4-5). Because Northampton County is largely agricultural, the fluctuations are attributed to changes in agriculture. Employment decline might be attributed to the earlier mentioned decrease in demand of agricultural products. As fruits and vegetables in the Eastern Shore were grown mostly manually, the cost of the products was higher than the products from other regions. The decline in employment might also be attributed to the decline in the natural resources in the adjacent Chesapeake Bay on which some of the population were making their living. Apparently, at the beginning of nineties farmers introduced more valuable crops such as cotton or tomatoes, which brought more revenue and required more work. Also at that time the prices for wheat went up and that might explain some increase in the employment (Luckenbach M. 2001, pers. comm.). The other source of employment that contributed to the growth was hard clam aquaculture. Demand for aquaculture products rose significantly and the aquaculture industry in the Eastern Shore grew as well. Even though the historic data shows that we might expect growth in the number of employed people, the forecasting model show uncertainty in what will happen in the future: historic decline in employment might repeat in the future. Recent years of employment growth (from 1992) suggest that it is likely that employment numbers will increase but the data set is too short to predict growth with certainty. 
We will never know if our forecast is good or not until the event happens and we can compare the results. In Fig. 4-6 we can see that because of the economy shift in 1992 the model was not able to forecast the future events correctly. Instead of growth the model showed further decline in employment. At this point we can make a conclusion that forecasting cannot be based only on statistics and historic data but we need to incorporate our own judgment. If we knew that some new crop was introduced, or new industry was coming to the county we probably could have predicted the sudden growth in employment.

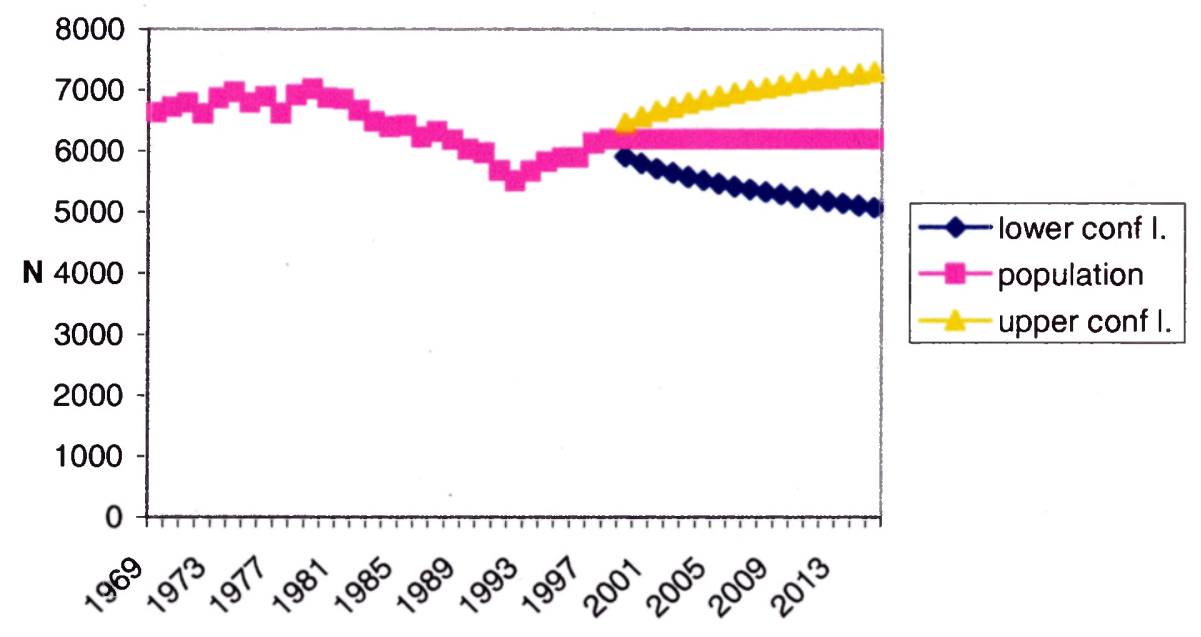

Figure 4-5. Baseline Scenario, Total Employment

Historic and Projected Number of People (N) 


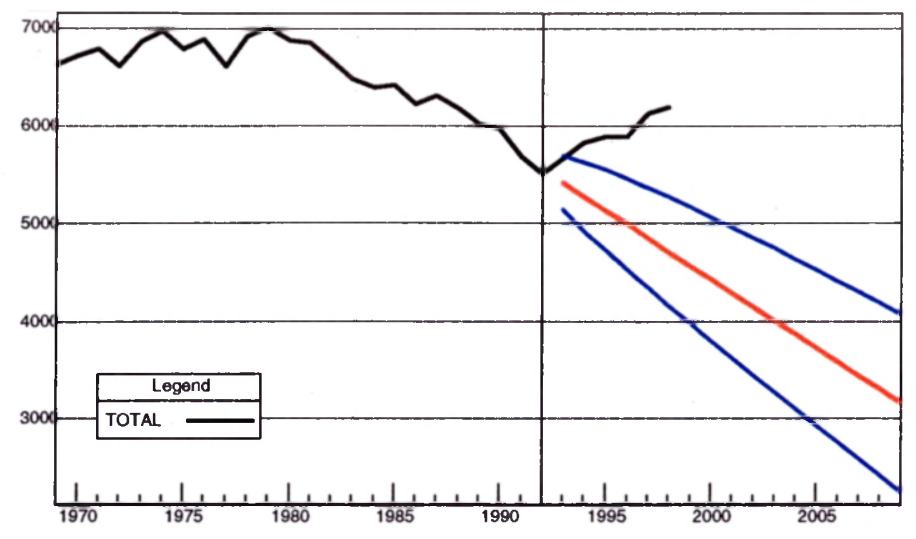

Figure 4-6. Employment forecast and historic data comparison with the forecast by holding out 6 history years (forecast - red line, historic data- black line, confidence intervals - blue line)

\section{Baseline Scenario: Income}

The income numbers showed a consistent trend through time. There was a slight decline in per capita personal income in 1989, but it lasted only for two years (Fig. 4-7). It is expected that per capita income will keep rising in the future as well. Probably the income increase can be attributed more to the overall national trend than to fluctuations in the local economy. Income growth in the County is lower, on average, than in the state or around the nation. 


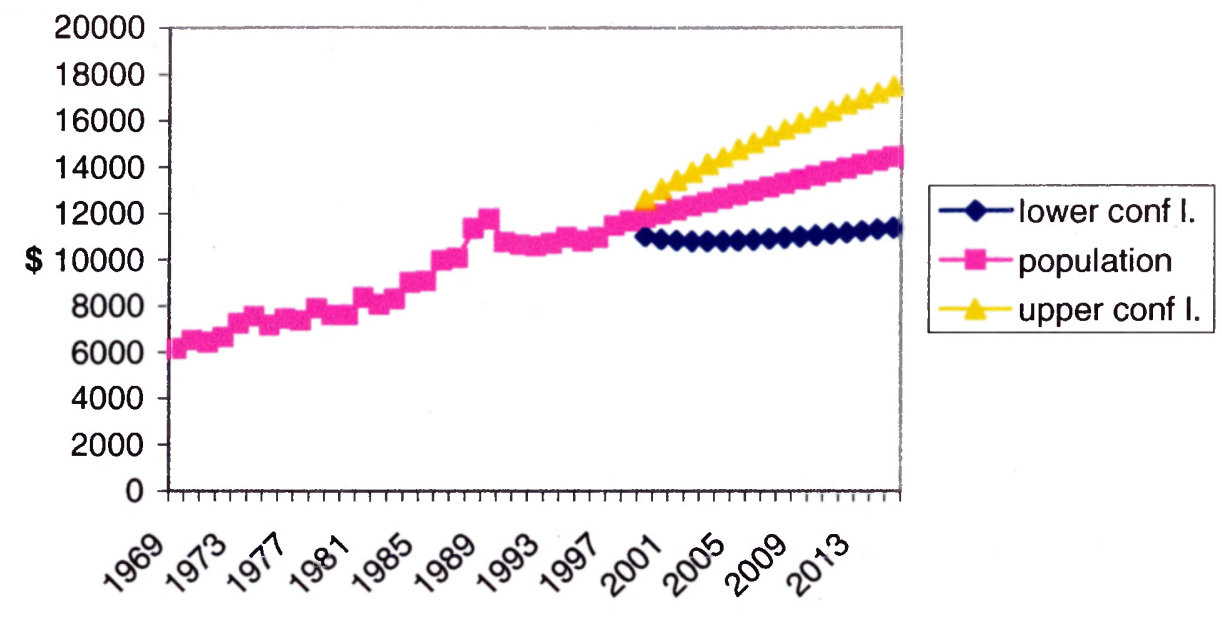

Figure 4-7. Baseline scenario per capita income, forecast and historic data

From examination of the forecast of historic information (Fig. 4-8) we see that the model performed very well: the difference between forecast and actual historic data did not exceed $\$ 100$ after six years.

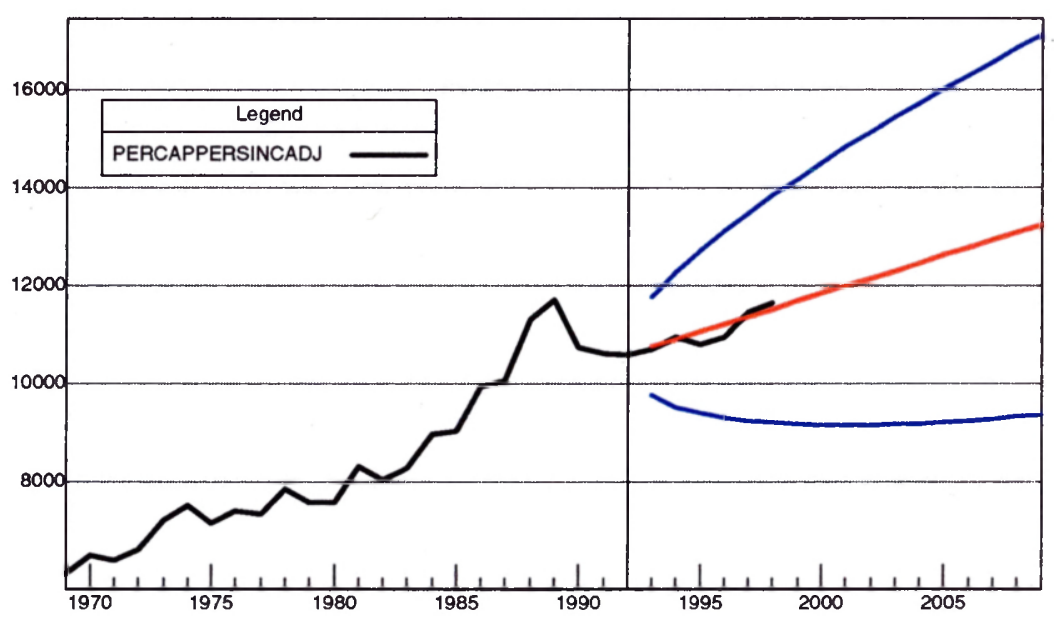

Figure 4-8. Baseline scenario per capita personal income, forecast and historic data comparison comparison by holding out 6 history years (forecast - red line, historic data- black line, confidence intervals - blue line) 
Total income closely followed the personal income pattern, perhaps because the number of people in Northampton County was fluctuating around 14 to 13 thousand (the total income equals the personal income times population). The hold out analysis confirmed the suitability of the model (Fig 4-10).

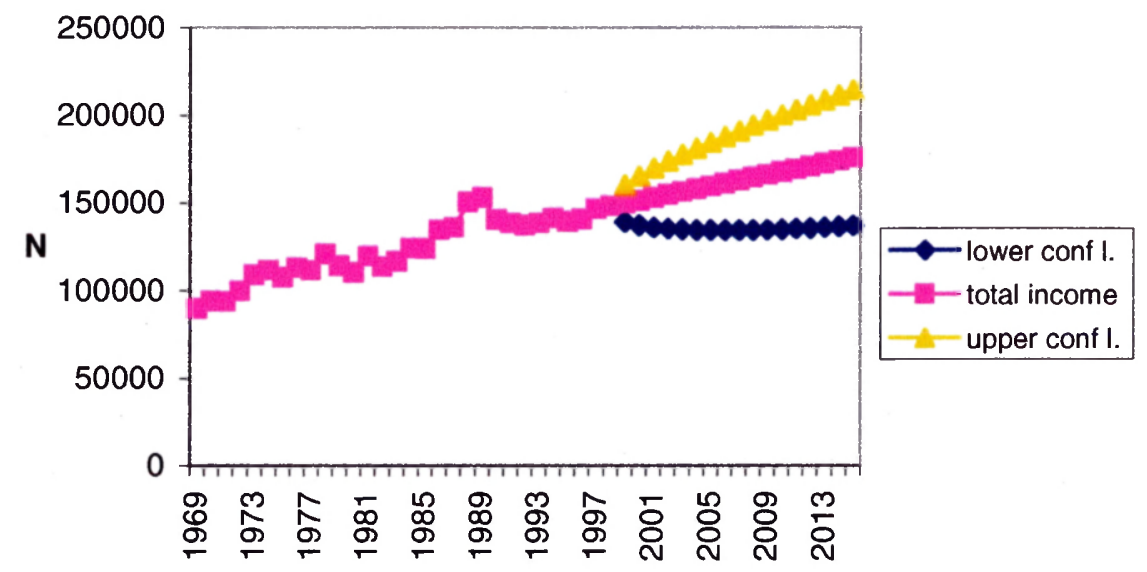

Figure 4-9. Baseline Scenario, total income forecast and historic data

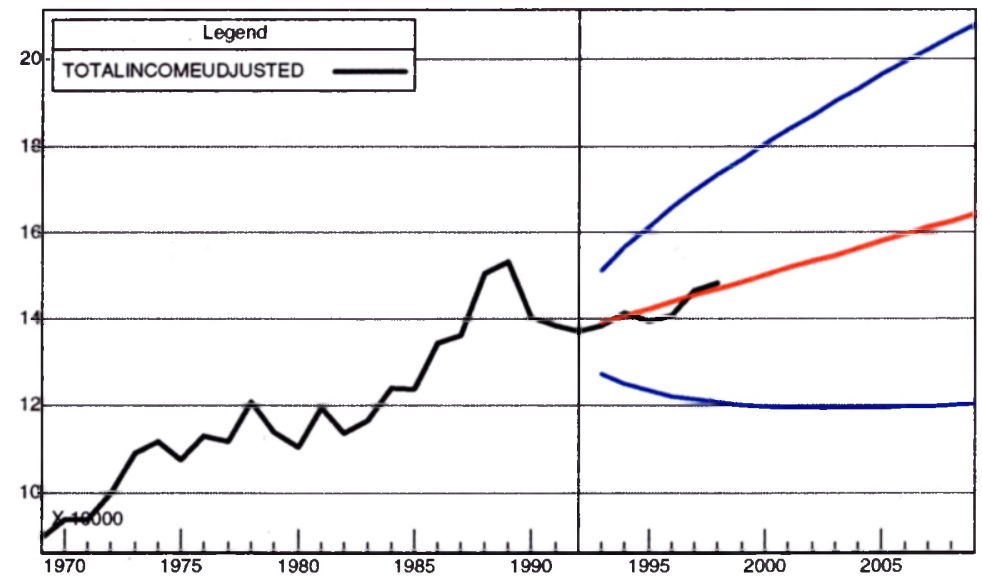

Figure 4-10. Total income forecast and historic data comparison by holding out 6 history years (forecast - red line, historic data- black line, confidence intervals - blue line) 
Baseline Scenario: Taxes

Tax policy in the region might be used as tool for development promotion. It appears to serve as a political tool. In table 4-4 we can see the tax rates for the Northampton County.

Table 4-3. Tax ration and tax rate in the Northampton County (bold text shows reassessment years)

\begin{tabular}{rrr} 
Year & \multicolumn{2}{c}{ Ration } \\
1978 & 70.6 & 0.78 \\
1979 & 63.8 & 0.78 \\
1980 & 70.6 & 1.09 \\
1981 & 66.9 & 1.09 \\
1982 & 75.8 & 1.09 \\
1983 & 66.7 & 1.09 \\
1984 & 84.9 & 0.77 \\
1985 & 84.2 & 0.77 \\
1986 & 92.2 & 0.77 \\
1987 & & - \\
1988 & 78.3 & 0.89 \\
1989 & 72.1 & 0.89 \\
1990 & 79.3 & 0.76 \\
1991 & 69.1 & 0.76 \\
1992 & 58.2 & 0.94 \\
1993 & 92.0 & 0.68 \\
1994 & 92.2 & 0.68 \\
1995 & 87.7 & 0.68 \\
1996 & 85.1 & 0.68 \\
1997 & - & - \\
1998 & 79.7 & 0.68 \\
1999 & 95.2 & 0.61
\end{tabular}

Ration is the ratio between real value of the land and the value, which was determined by the Northampton County Commissioner of Revenue. The rate is the number representing how much people pay in tax for their property for each $\$ 100$ in assessed value. It seems that Northampton County is trying to keep the tax rates the same over time. Reassessments are performed when the land value assigned by county officials does not match the real commercial value. After reassessment the ration is also changing. 
In this way the county is able to keep their taxes constant over time which might be important for the elected officials (aiding reelection). Also, relatively low taxes attract more investment and development into the county. Nationally recognized for its conservative fiscal practices, Virginia has one of the fairest and most stable tax structures of the 50 states. The state corporate income tax has not increased since 1972. And on Virginia's Eastern Shore real estate tax rates are low (Eastern Shore of Virginia Economic Development Commission. 2001). In 1994 Northampton County was ranked as the second most fiscally stressed locality out of 136 in the Commonwealth (Northampton County Board...,1994). Apparently the county revenue from the taxes are not high and are designed to meet the basic needs of the municipality (building schools, maintenance of local government, etc.). For example the Town of Cape Charles total budget was $\$ 1,820,592$ in fiscal year 2001 from which $41 \%$ is provided through some type of governmental grant support, $26 \%$ is from the utility services provided by the Town and paid by the users. The tax money provides only about $13 \%$ of the revenue. And that number is comprised of real estate and personal property taxes together. It clearly suggests that reliance on grant funding for basic services must be weaned. The state government reduced the grant funds from over $50 \%$ just a couple of years ago (Chirps, 2000).

The Town of Cape Charles input to the revenues from real estate taxes is increasing. In Table 4-5 we can see that a decade ago revenues from the Town were around 5 percent to the whole Northampton County. In the year 2000 revenues amounted to 7 percent. This increase is already attributed to the Bay Creek development. 
Tax information is limited:

Table 4-4. Tax revenues dynamics

\begin{tabular}{|l|l|l|l|l|l|}
\hline & 1984 & 1985 & 1986 & 1987 & 2000 \\
\hline $\begin{array}{l}\text { Cape Charles } \\
\text { (CC) }\end{array}$ & 99,500 & 100,374 & 112,532 & 113,166 & 331,497 \\
\hline $\begin{array}{l}\text { Northampton } \\
\text { County (NC) }\end{array}$ & $1,967,976$ & $1,983,772$ & $2,010,160$ & $2,047,927$ & $4,592,500$ \\
\hline $\begin{array}{l}\text { Ratio of CC } \\
\text { to NC }\end{array}$ & 5.06 & - & - & 5.52 & 7.21 \\
\hline
\end{tabular}


Population: Agriculture, Forest and Golf Course Scenarios

Anticipated population numbers in Northampton County in different development scenarios are presented in Fig. 4-11. It was assumed that, in the whole Northampton County, population dynamics will remain steady, and only in the proposed development area there will be changes. In other words, the forecasts for the whole Northampton County were taken and the forecasts only for the proposed development area were added to them. According to the selected counties profiles the anticipated growth for the Agriculture scenario were 1.54 percent, and 0.19 percent for Forest. The growth rate for the Golf Course scenario was determined from the cost benefit analysis. In the case of the Forest scenario even though there is an expected growth in the area of Cape Charles the whole county would remain in steady state and that is why we see the forecasted decline in the population. The Agriculture growth rates are faster but the whole county "weight" still keeps the number stagnant. In the case of the Golf Course there is an anticipated exponential growth of population, which will affect the whole county population growth. It is expected that the rate will be exponential because people will start to move to the new development more readily when initial settlement has already begun. Developers have several scenarios in regard to how many households the area will accommodate. The maximum number of people is calculated to be 3,000 households. Home construction will be adjusted according to demand: if there will be more people willing to buy larger and more expensive homes there will be fewer home units. If people choose the less expensive houses the developers will try to accommodate more houses per unit area. The scenario upon to which the forecasts were based is calculated to accommodate 2,500 households. 
In the Forest scenario it is expected that part or even all forest might be designated as a national park or reserve which would attract some tourist and visitors.

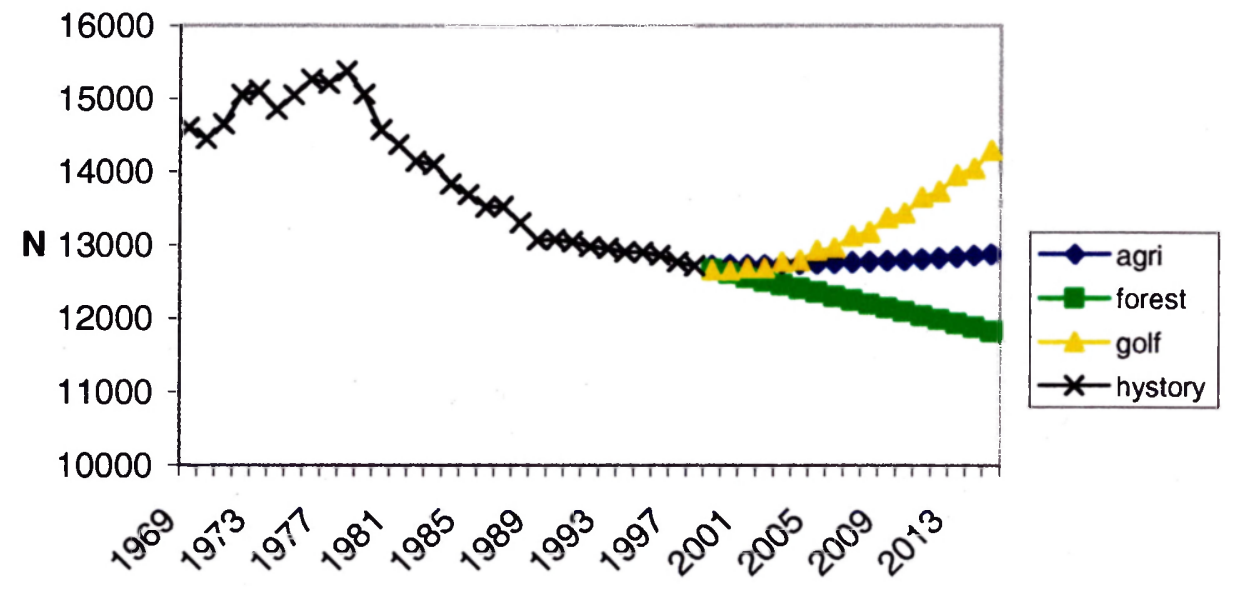

Figure 4-11. Agriculture, Forest and Golf Course Scenarios Population Historic and Projected Series Number of People (N) 
Employment: Agriculture, Forest and Golf Course Scenarios

It is expected that under all development scenarios employment would rise: only by few employment positions in the case of Forest scenario ( 0.11 percent growth according to counties in Virginia). Moderate growth is expected in the Agriculture scenario ( 1.02 percent growth according to selected counties in Virginia) and exponential for the Golf Course scenario (Figure 4-12).

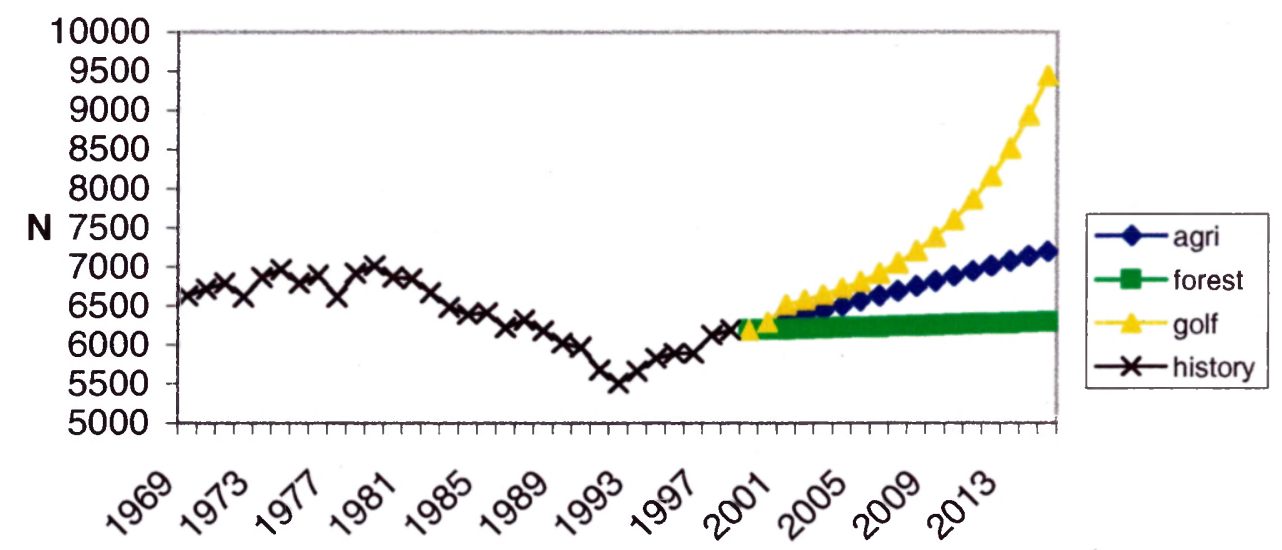

Figure 4-12. Agriculture, Forest and Golf Course Scenarios Total Employment Historic and Projected Series Number of People (N)

For employment forecasts for agriculture and forest scenarios coefficients were used for the counties in Virginia. In the case of the Golf Course scenario the cost benefit analysis of the Bay Creek Development was used (Fiscal and Economic Impacts Highlights, 1996).

The numbers show the growth only in the area of the proposed development on the assumption that the other part of the county would develop at the same rate as it was developing before (the growth rate was added to the forecasted Baseline scenario numbers). 
Per Capita Income: Agriculture, Forest and Golf Course Scenarios

In order to better assess the change in income dynamics in Northampton County the actual dollar values were converted to constant dollar values using the consumer price index of years 1982-1984. The difference in those two dollar values are presented in Fig. 4-13.

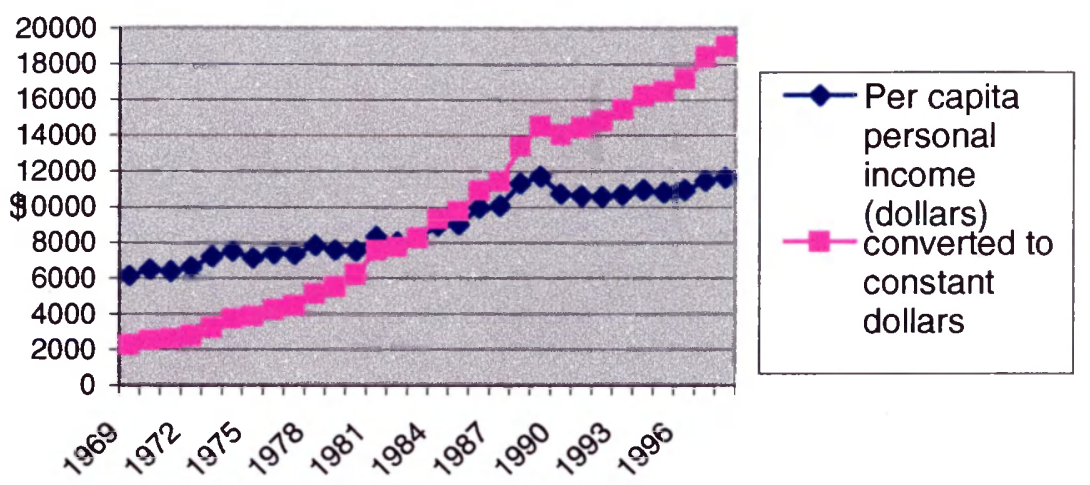

Figure 4-13. Personal Income (actual and constant dollars)

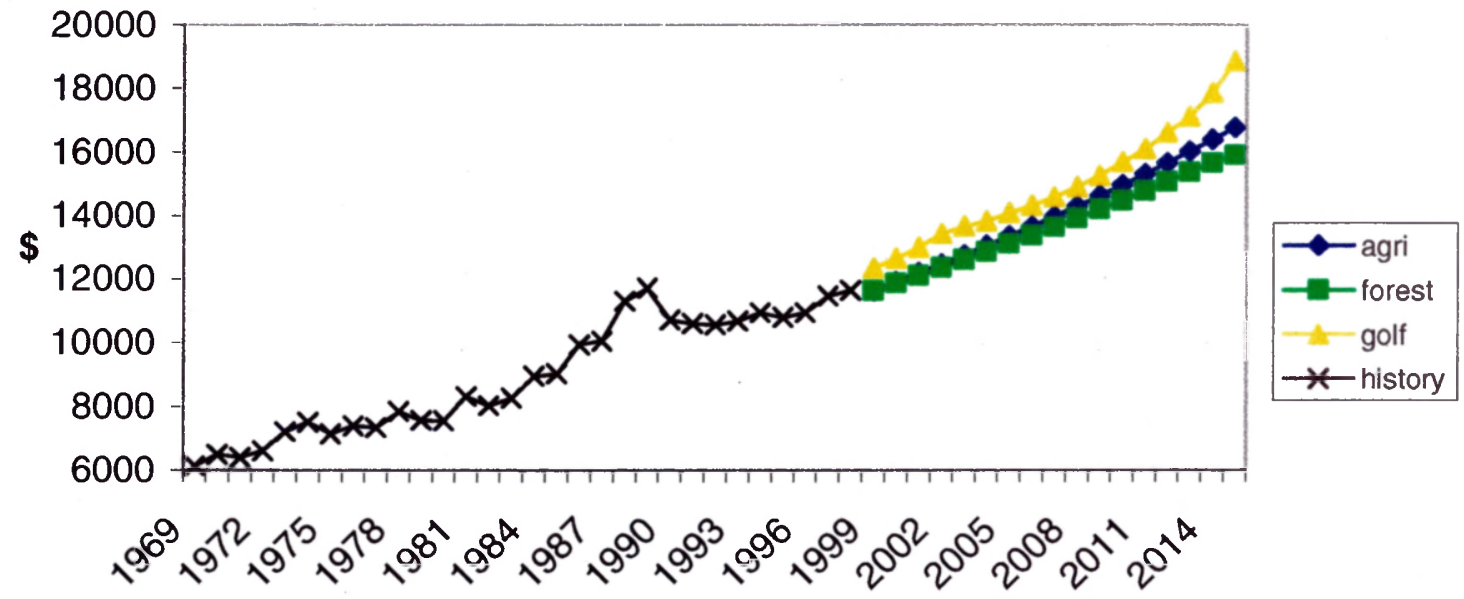

Figure 4-14. Agriculture, Forest and Golf Course Scenarios per capita income

Historic and Projected Series (\$) 
For the forecast of per capita income in Northampton County the dynamic regression was used to forecast the personal income growth in Golf scenarios (Fig. 4-14). In the case of Agriculture and Forest scenarios independent variables were the counties in Virginia. (The growth rate for Agriculture was 2.3 percent, Forest scenario - 2.2 percent). First the income in those counties was forecasted using a univariate exponential technique, then the forecast was used to forecast variables in the Northampton county. The numbers represent the whole county growth. Cape Charles area is not separated. There is a projected growth in income for all scenarios but unlike population and employment we do not see big differences between different cases. The salaries are probably stable through the time and would be different if some hi-tech company would come to the county. But in rural development (agriculture and forest and to some extent retirement communities) growth provides jobs that are not high skilled and very well paid. In the case of the Golf Course the new jobs would be mainly service type. The type of work that people would be working in the different scenarios is already present in the Baseline scenario: the difference would be that there would be more positions. A quite different picture is seen for total income where the number of people is included in the income equation. We would expect that the total income would rise with population numbers (Fig. 4-11).

The exponential growth in the case of personal and total income might be explained by the fact that the regression model captures the cycle from history and extrapolates it to the future. 
Total Income: Agriculture, Forest and Golf Course Scenarios

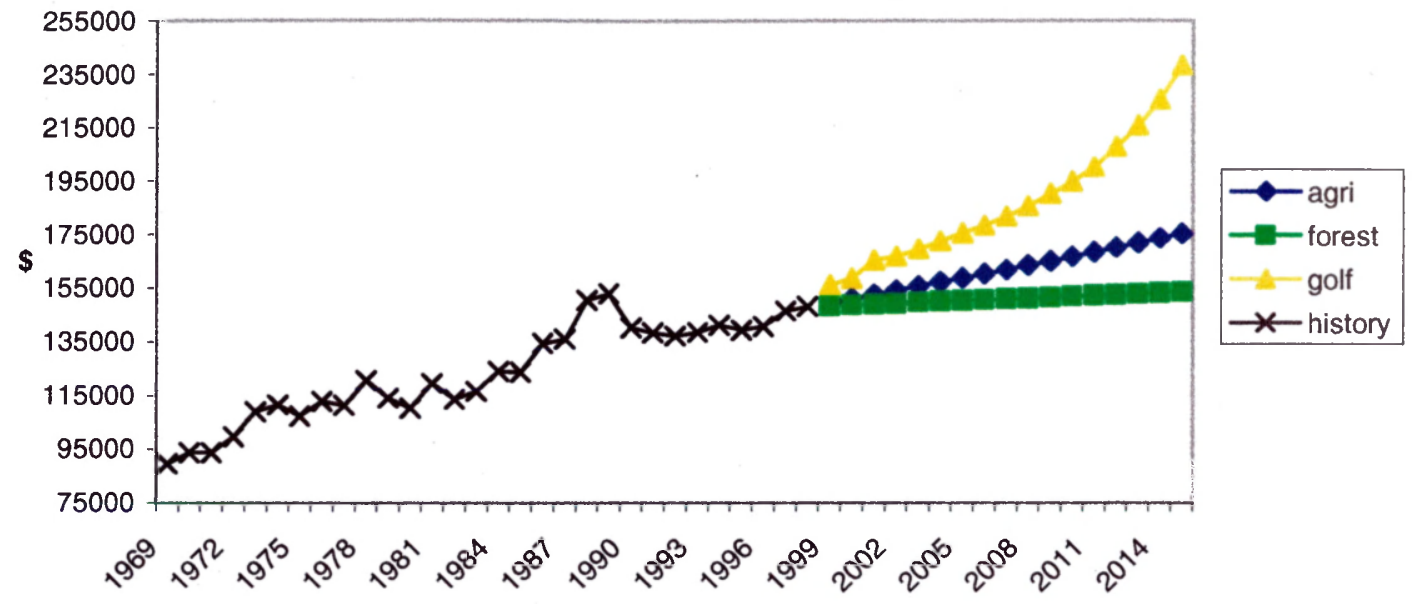

Figure 4-15. Agriculture, Forest and Golf Course Scenarios Total Income Historic and Projected Series (\$)

The forecast of total income in Northampton County under different scenarios was performed using techniques similar to those employed for per capita income. For the Agriculture and Forest scenarios, the income of counties in Virginia was first forecasted using an exponential smoothing technique (the growth rates were for Agriculture scenario 1 percent, for Forest 0.2 percent). Then the forecast was used to forecast the Northampton County total income taking the forecast of other counties as an independent variable. The Golf Course scenario total income was forecasted using the employment forecasts as an independent variable in dynamic regression technique (Figure 4-15).

Development represents the whole county. Cape Charles is not excluded as in the case of population and employment. 


\subsection{Discussion}

Population numbers were declining during the last two decades in the Northampton County. It might be attributed to single events such as Chesapeake Bay Bridge Tunnel construction (and people leaving Cape Charles as a result), mechanization of agriculture techniques, or decline in natural resources on which part of the population in the county were dependent. Some people switched to new jobs, but apparently during this time no new industries came to the county. The growing aquaculture business was not able to accommodate all unemployed people. Part of them left the county. If we look into the forecast we see that under current conditions the population numbers will go down and the employment would stay stagnant through time. There is an optimistic trend from 1992 that there will be more jobs, but examination of history shows similar variability in employment numbers. That is why the exponential smoothing model is showing that in the future the job market might increase but with the same probability it might decrease. In the case of the employment forecast we see that we can not always rely on statistical forecasting technique: we have to use our own judgement. In 1992 there was some positive impact on the local job market and the jobs numbers went up. The forecasting model could not predict that. But if we knew that some industry is coming in to the region we might have included those expected parameters.

Income, opposite to the previous cases of population and employment, is rising. Probably the income numbers are tied more to the general well-being of the economy of 
the state and the whole country. There is a national minimum wage and people who work year round most likely earn enough money to sustain themselves. The problem is with the people who have seasonal work (e.g. in agriculture) and families with more people in the household.

It appears that Northampton County maintains a conservative tax policy that benefits only a part of the population. While additional revenues would allow county officials to better discharge their duties, raising taxes is politically unpopular and they would probably lose their positions in local government. The greatest part of the municipality's money goes to the school system and yet the education in the county is in a very bad situation. Big part of the population are retired people who do not personally use or need a good school system and very often they are the most influential interests groups in the locality: they vote in elections and participate in the county's political life. Those with the biggest needs can be forgotten.

Not all development scenarios would bring more people to the county. According to other counties information, forest development would bring stagnation to the county and population would keep declining. If the agriculture scenario is implemented the population would stop decreasing. The developers think that, at some point, with the implementation of their proposal of building golf course and a residential area the population numbers would reach the numbers that were observed 20 years ago.

Northampton County's economy was already based on agriculture and the development scenarios such as all agriculture means that probably some other things should change in the county other than land use percentage. For example, the crops that farmers use in selected counties in Virginia and on the Eastern Shore are the same but 
how people go about distributing fruits and vegetables to other regions or what techniques they use can vary. As Eastern Shore is isolated from the rest of the Commonwealth this situation should have to change if we want to see some positive changes in the county's economy. In the case of the Forest scenario probably the forest itself would not bring money, but would benefit the tourism industry.

Local people in the Eastern Shore are opposing development, and the biggest issue is the Chesapeake Bay Bridge toll. Currently it is an elevated $\$ 20$ and most likely it is the reason why people are avoiding the Eastern Shore. But there are the discussions going on to reduce the toll. The study "Potential Land Use Impacts of a Commuter Toll Reduction on the Chesapeake Bay Bridge-Tunnel" (1999) revealed that the reduction of the toll would have positive impact on local economy.

Most of the people who expressed their opinion about the toll reduction are saying that they do not want the lower toll because it would destroy their quiet life. There is an opinion that commuters from Hampton Roads area (Norfolk, Virginia Beach) would move to the Eastern Shore and commute every day to the work on the mainland and it is expected that that would bring a lot of development to the Northampton County. The above study also stated that that would not happen in the nearest future, and the biggest impact would be from retirement communities. 


\section{FINAL RESULTS AND DISCUSSION}

An integrated approach towards development problems is new and controversial. There have been attempts to create models integrating environmental and socioeconomic issues but most outcomes have been theoretical. While we cannot ignore environmental degradation, development is necessary. Ultimately, people will decide what happens to the inland. We can only alert people to the obstacles, they might be facing if they develop without consideration of environmental impacts.

The Chesapeake Bay Program has been successful in preserving the Bay resources, but the progress could be lost due to uncontrolled development. This study revealed that with development nutrient and suspended solids input to the Old Plantation Creek would increase up to three times (nitrogen in the Agriculture scenario, phosphorus in the Golf Course scenario) (Table 5-1). The best scenario from an environmental perspective would be Forest. On the other hand this investigation suggests that Old Plantation Creek water quality would not deteriorate because of increased pollutant loads (Table 5-2). This might serve as a good excuse for the developers to start developing the area because nature may assimilate all excessive pollutants. However, this case needs further investigation because with increased loads the likelihood of higher temporal pollution (e.g. storm events) also increases. Also the pollution effects to ground waters need investigation. 
Examination of socioeconomic parameters showed (Table 5-1) that the highest employment and income numbers would result from the Golf Course scenario.

Conservative development and management practices such as Agriculture or Forest would not be as effective in raising the quality of life for local people as Golf Course. The worst scenario would result from the county remaining in its present (Baseline) situation. It is important to notice that the Baseline scenario has agriculture and forest already as the main land uses and in general it should show better results relative to Forest and Agriculture scenarios. For that matter, we should probably look for other reasons why other Agricultural or Forested counties are doing better than Northampton County. One of the reasons might be the isolation of Northampton County from the rest of the state.

Table 5-1. Nutrient and suspended solid loads to the O. P. Creek and anticipated Income and Employment indices under different development scenarios

\begin{tabular}{c|ccrr} 
& \multicolumn{4}{|c}{ Scenarios } \\
& Baseline & Agriculture & \multicolumn{1}{c}{ Forest } & Golf Course \\
Parameter & 3.1189 & 10.9213 & 0.4227 & 4.6471 \\
\hline Total Nitrogen (t/y) & 0.1778 & 0.2706 & 0.0133 & 0.3903 \\
Total Phosphorus (t/y) & 20.9062 & 30.0432 & 0.0100 & 21.4834 \\
Suspended Solids (t/y) & 6,189 & 7,199 & 6,298 & 9,448 \\
\hline $\begin{array}{c}\text { Employment (number } \\
\text { of people) }\end{array}$ & 14,416 & 16,765 & 15,904 & 18,865 \\
$\begin{array}{c}\text { Per Capita Income (\$) } \\
\text { Total Income (\$) }\end{array}$ & 175,713 & 175,533 & 153,858 & 238,533
\end{tabular}


Table 5-2. Average concentrations of nutrients and chlorophyll a in the Old Plantation Creek under different development scenarios

\begin{tabular}{c|cccc} 
Parameter & $\begin{array}{l}\text { Scenarios } \\
\text { Baseline }\end{array}$ & Agriculture & Forest & Golf Course \\
\hline Chlorophyll a $(\mu \mathrm{g} / \mathrm{l})$ & 7.9 & 8.4 & 7.8 & 8.0 \\
$\begin{array}{c}\text { Dissolved inorganic } \\
\text { nitrogen (DIN) }(\mu \mathrm{g} / \mathrm{l})\end{array}$ & 22 & 24 & 21 & 23 \\
$\begin{array}{c}\text { Dissolved inorganic } \\
\text { phosphorus (DIP) }(\mu \mathrm{g} / \mathrm{l})\end{array}$ & 13.4 & 12.7 & 13.5 & 13.5
\end{tabular}




\section{POLICY IMPLICATIONS}

Land use and water quality are closely related issues. The experience of the Chesapeake Bay Program and others show that management practices on the land affect not only the local economy but also the quality of the natural environment. It is often emphasized that we have to protect environmental resources, and support for those policies has been expressed in different strategies, programs and legislative acts (see text for more details). On the other hand the objective of every planning manager is to increase the wealth of people, provide them with jobs, give educational opportunities, etc. The ways to achieve those objectives include strengthening the local economy by introducing new industries, promoting development, encouraging the growth of economy through tax policies, etc. Usually economic goals are in conflict with environmental preservation.

In our study we found that the Baseline scenario so far was clearly acceptable only for part of the population of Northampton County. The unemployment rates were high, income low and people were moving out of the area. A similar trend could be projected into the future, which suggest that some new approaches should be adopted in the County economic planning efforts. From the perspective of environmental quality the Baseline scenario is not the "cleanest" one. There are farms, residential areas, but not a lot of forest cover.

The better alternative from the economic perspective would seem to be the Agriculture scenario (to convert all existing land to agricultural fields). This scenario would bring more revenues and create more job opportunities. But we know that 
agriculture provides seasonal jobs which solve the problem of unemployment only in particular seasons. Also the products produced in the Eastern Shore were not as competitive in the markets as the produce from other regions (because of human labor intensive techniques, particular types of crops, etc.). From the environmental point of view the Agriculture scenario would be one of the worst scenarios with the highest yields of nitrogen and suspended solids in runoff. In order to accept this scenario, many tradeoffs would have to be accepted. The ways to overcome obstacles would be to switch for example to organic farming in which case the nutrient runoff problem would be lessened. Also some new crops should be introduced but even then the employment problem would not be solved because newer agriculture techniques require less human labor.

The Forest scenario is one of the most pristine development scenarios investigated in this study. The vegetation would take up all the nutrients, and the vegetation land cover would prevent suspended solids runoff. Also, there would not be additional artificial (human) nutrients adding to the system. From the economic perspective, however, forest alone would not bring any added revenues or jobs. The other possible source of revenues would come from devoting the forest to tourism (for example a national park). That is what the other compared counties in Virginia are noted for.

The Agriculture and Forest scenarios were created according information from similar counties in Virginia. To achieve similar growth rates in Northampton County, the other variables should be taken into consideration. One of the controversial issues on the Eastern Shore is its isolation. If we expect the Agriculture or Forest scenario to work for 
the local economy as it does for the compared counties, we probably would have to increase accessibility to the Eastern Shore.

The Golf Course scenario was expected to be the most disastrous for the environment of the Eastern Shore: fertilizer applications to golf courses would be three times those in agriculture. The model results, however, showed that only in the case of phosphorus were the loads actually the highest in the Golf Course scenario. The moderate pollution from the Golf Course scenario is probably due to diversity of land uses in the new development: wetlands are expected to be preserved and there will be some forest cover. Also, grassland practices are different than agriculture ones in that the land does not stay without cover in spring and autumn months.

To sum up we can say that the Baseline scenario is not acceptable. In the case of the Agriculture and Forest scenarios, the projections should be viewed with caution because this is a comparative study and other factors (such as isolation) might cause management practices failure. So if one of those scenarios should be pursued additional factors should be investigated. But the potential is there.

It appears that the Golf Course scenario would be the most acceptable from all investigated scenarios from the economic perspective. The impacts of the development would have not only local (area of Cape Charles) but also regional effects (Northampton County level and even the whole Eastern Shore). The environmental problems would still be there but not as severe as expected. Further reduction of environmental impacts should be considered by developers. The models used in the study incorporate only the general pattern of land use (percentage of different land uses) and does not include such aspects as location of, for example, the critically important wetlands or forest cover. 
Most likely establishment and maintenance of the buffer zone between land and water would improve the water quality in adjacent creeks. In other words implementation of Best Management Practices would help solve some of the environmental problems.

The earlier-mentioned improvements are incorporated into management plans of the Bay Creek Development but the statement that pollution loads would be lower than in the Baseline scenario raise a question about the validity of the models used by the consulting firms for the Bay Creek. 


\section{FUTURE RESEARCH}

Our study revealed some issues that could not be investigated in this project due to limitations of techniques used and time constraints. First, the techniques used were not as accurate as we might have wanted. Predicted pollutant loads are calculated on a monthly basis. From other research we know that at times what is the most important are those random events (storms) which increase the likelihood of the dangerous pollutant runoff and concentrations. The impact of the Chesapeake Bay was one of the issues that corrected our results significantly and the impacts of the larger water body to a comparatively small creek should be investigated in more detail. Also the cumulative impacts of the creeks and rivers on the Chesapeake Bay should not be forgotten while investigating the systems (we should see the bigger picture while investigating the matter). One more factor not completely understood is the influence of groundwater to the pollutants runoff. The model results and other research showed that the groundwater might be very influential.

There is some information that clam filtering might have a significant impact on water quality. The investigated Old Plantation Creek has the most extensive commercial clam beds in the entire Eastern Shore. It is known that one clam can filter few gallons of water in few hours, and there are millions of clams in the Creek. 
From the socioeconomic perspective a cost benefit analysis should be done in order to see what would be the real benefits from the alternative scenarios. In this study, for example, such important factors as geographical location were not taken into consideration.

Probably one of the most important thing in management and planning should be the public's opinion about the development or conservation perspectives. Surveys would probably help to answer a lot of questions and would help avoid mistakes that might be committed in the planning efforts. 


\section{APPENDIX}

\section{APPENDIX A}

Table 3-A. TPWQM simulation for the Old Plantation Creek different segment and different development scenarios.

\begin{tabular}{|c|c|c|c|c|c|c|c|c|c|}
\hline BCD & SAL & CHL & TP & OP & PO4t & TN & ON & NH4 & NO3 \\
\hline$(\mathrm{km})$ & $(\mathrm{ppt})$ & $\left(\mathrm{mg} / \mathrm{m}^{\wedge} 3\right)$ & $\left(\mathrm{g} / \mathrm{m}^{\wedge} 3\right)$ & $\left(\mathrm{g} / \mathrm{m}^{\wedge} 3\right)$ & $\left(\mathrm{g} / \mathrm{m}^{\wedge} 3\right)$ & $\left(\mathrm{g} / \mathrm{m}^{\wedge} 3\right)$ & $\left(\mathrm{g} / \mathrm{m}^{\wedge} 3\right)$ & $\left(\mathrm{g} / \mathrm{m}^{\wedge} 3\right)$ & $\left(\mathrm{g} / \mathrm{m}^{\wedge} 3\right)$ \\
\hline $1-0.5000 E+00$ & 20.0 & 8.3300 & 0.0210 & 0.0130 & 0.0080 & 0.3200 & 0.3000 & 0.0120 & 0.0080 \\
\hline $20.1480 E+01$ & 19.8 & 7.5800 & 0.0348 & 0.0123 & 0.0124 & 0.3840 & 0.2870 & 0.0145 & 0.0064 \\
\hline $30.3630 E+01$ & 19.3 & 7.4900 & 0.0369 & 0.0119 & 0.0146 & 0.3710 & 0.2780 & 0.0133 & 0.0048 \\
\hline $40.4860 E+01$ & 18.3 & 7.3600 & 0.0386 & 0.0116 & 0.0166 & 0.3600 & 0.2700 & 0.0128 & 0.0038 \\
\hline
\end{tabular}

\begin{tabular}{|c|c|c|c|c|c|c|c|c|c|}
\hline OPC & SAL & CHL & TP & OP & PO4t & TN & ON & NH4 & NO3 \\
\hline$(\mathrm{km})$ & $(\mathrm{ppt})$ & $\left(\mathrm{mg} / \mathrm{m}^{\wedge} 3\right)$ & $\left(\mathrm{g} / \mathrm{m}^{\wedge} 3\right)$ & $\left(\mathrm{g} / \mathrm{m}^{\wedge} 3\right)$ & $\left(\mathrm{g} / \mathrm{m}^{\wedge} 3\right)$ & $\left(\mathrm{g} / \mathrm{m}^{\wedge} 3\right)$ & $\left(\mathrm{g} / \mathrm{m}^{\wedge} 3\right)$ & $\left(\mathrm{g} / \mathrm{m}^{\wedge} 3\right)$ & $\left(\mathrm{g} / \mathrm{m}^{\wedge} 3\right)$ \\
\hline $1-0.5000 \mathrm{E}+00$ & 20 & 8.33 & 0.021 & 0.013 & 0.008 & 0.32 & 0.3 & 0.012 & 0.008 \\
\hline $20.1480 \mathrm{E}+01$ & 19.8 & 7.81 & 0.0349 & 0.0124 & 0.0121 & 0.388 & 0.287 & 0.0161 & 0.0066 \\
\hline $30.3630 \mathrm{E}+01$ & 19.6 & 8.03 & 0.0373 & 0.0122 & 0.0141 & 0.38 & 0.278 & 0.0159 & 0.0051 \\
\hline $40.4860 \mathrm{E}+01$ & 19.3 & 8.22 & 0.0394 & 0.012 & 0.0159 & 0.373 & 0.269 & 0.0173 & 0.0043 \\
\hline
\end{tabular}

\begin{tabular}{|c|c|c|c|c|c|c|c|c|c|}
\hline BCDagri & SAL & CHL & TP & OP & PO4t & TN & ON & NH4 & NO3 \\
\hline$(\mathrm{km})$ & $(\mathrm{ppt})$ & $\left(\mathrm{mg} / \mathrm{m}^{\wedge} 3\right)$ & $\left(\mathrm{g}^{\left./ \mathrm{m}^{\wedge} 3\right)}\right.$ & $\left(\mathrm{g} / \mathrm{m}^{\wedge} 3\right)$ & $\left(\mathrm{g} / \mathrm{m}^{\wedge} 3\right)$ & $\left(\mathrm{g} / \mathrm{m}^{\wedge} 3\right)$ & $\left(\mathrm{g} / \mathrm{m}^{\wedge} 3\right)$ & $\left(\mathrm{g} / \mathrm{m}^{\wedge} 3\right)$ & $\left(\mathrm{g} / \mathrm{m}^{\wedge} 3\right)$ \\
\hline $1-0.5000 \mathrm{E}+00$ & 20.0 & 8.3300 & 0.0210 & 0.0130 & 0.0080 & 0.3200 & 0.3000 & 0.0120 & 0.0080 \\
\hline $20.1480 \mathrm{E}+01$ & 19.8 & 7.7800 & 0.0348 & 0.0124 & 0.0120 & 0.3890 & 0.2880 & 0.0156 & 0.0065 \\
\hline $30.3630 \mathrm{E}+01$ & 19.3 & 8.0100 & 0.0369 & 0.0122 & 0.0138 & 0.3820 & 0.2820 & 0.0148 & 0.0050 \\
\hline $40.4860 \mathrm{E}+01$ & 18.3 & 8.2500 & 0.0388 & 0.0120 & 0.0152 & 0.3800 & 0.2760 & 0.0173 & 0.0044 \\
\hline
\end{tabular}

\begin{tabular}{|c|c|c|c|c|c|c|c|c|c|}
\hline BCDforest & SAL & CHL & TP & OP & PO4t & TN & ON & NH4 & NO3 \\
\hline$(\mathrm{km})$ & $(\mathrm{ppt})$ & $\left(\mathrm{mg} / \mathrm{m}^{\wedge} 3\right)$ & $\left(\mathrm{g} / \mathrm{m}^{\wedge} 3\right)$ & $\left(\mathrm{g} / \mathrm{m}^{\wedge} 3\right)$ & $\left(\mathrm{g}^{/ \mathrm{m}^{\wedge} 3}\right)$ & $\left(\mathrm{g} / \mathrm{m}^{\wedge} 3\right)$ & $\left(\mathrm{g} / \mathrm{m}^{\wedge} 3\right)$ & $\left(\mathrm{g} / \mathrm{m}^{\wedge} 3\right)$ & $\left(\mathrm{g} / \mathrm{m}^{\wedge} 3\right)$ \\
\hline $1-0.5000 \mathrm{E}+00$ & 20 & 8.33 & 0.021 & 0.013 & 0.008 & 0.32 & 0.3 & 0.012 & 0.008 \\
\hline $20.1480 \mathrm{E}+01$ & 19.8 & 7.5 & 0.0347 & 0.0122 & 0.0124 & 0.382 & 0.287 & 0.014 & 0.0063 \\
\hline $30.3630 \mathrm{E}+01$ & 19.3 & 7.31 & 0.0366 & 0.0118 & 0.0147 & 0.367 & 0.277 & 0.0124 & 0.0047 \\
\hline $40.4860 \mathrm{E}+01$ & 18.3 & 7.07 & 0.0382 & 0.0114 & 0.0169 & 0.354 & 0.268 & 0.0115 & 0.0037 \\
\hline
\end{tabular}

\begin{tabular}{|c|c|c|c|c|c|c|c|c|c|}
\hline BCDgolf & SAL & CHL & TP & OP & PO4t & TN & ON & NH4 & NO3 \\
\hline$(\mathrm{km})$ & (ppt) & $\left(\mathrm{mg} / \mathrm{m}^{\wedge} 3\right)$ & $\left(\mathrm{g} / \mathrm{m}^{\wedge} 3\right)$ & $\left(\mathrm{g} / \mathrm{m}^{\wedge} 3\right)$ & $\left(\mathrm{g} / \mathrm{m}^{\wedge} 3\right)$ & $\left(\mathrm{g} / \mathrm{m}^{\wedge} 3\right)$ & $\left(\mathrm{g} / \mathrm{m}^{\wedge} 3\right)$ & $\left(\mathrm{g} / \mathrm{m}^{\wedge} 3\right)$ & $\left(\mathrm{g} / \mathrm{m}^{\wedge} 3\right)$ \\
\hline $1-0.5000 \mathrm{E}+00$ & 20 & 8.33 & 0.021 & 0.013 & 0.008 & 0.32 & 0.3 & 0.012 & 0.008 \\
\hline $20.1480 \mathrm{E}+01$ & 19.8 & 7.63 & 0.035 & 0.0123 & 0.0124 & 0.385 & 0.287 & 0.0149 & 0.0064 \\
\hline $30.3630 \mathrm{E}+01$ & 19.3 & 7.6 & 0.0372 & 0.012 & 0.0147 & 0.374 & 0.279 & 0.0137 & 0.0048 \\
\hline $40.4860 \mathrm{E}+01$ & 18.3 & 7.52 & 0.0391 & 0.0118 & 0.0167 & 0.364 & 0.271 & 0.0136 & 0.0039 \\
\hline
\end{tabular}


Glossary for Environmental Indicators Section

Pollutants - suspended solids, nitrogen, phosphorus, chlorophyll a. In some cases the word "pollutants" is used to generalize the materials mentioned above and does not necessarily have negative value

$\mathrm{N}$ - nitrogen

$\mathrm{P}$ - phosphorus

Chl "a" - chlorophyll "a"

The creek - the Old Plantation Creek

Lower, Middle and Upper Creek is the same as $1^{\text {st }}, 2^{\text {nd }}, 3^{\text {rd }}$ segments

BCD - Baseline scenario also "baseline" in figures

BCDagri - Agriculture also "agri" in figures

BCDforest - Forest scenario also "forest" in figures

BCDgolf - Golf course scenario, also Golf Course/Residential Area also Bay Creek Development - the name of the proposed development. (The area where golf course/residential area will be built) also "golf" in figures

OPC - Old Plantation Creek/"Whole" watershed - the entire Old Plantation Creek watershed (Bay Creek Development/Golf Course/Residential area scenario comprise only $1 / 4$ of the whole watershed)

Baseline scenario represents year 1989. The area is based on the proposed Bay Creek Development watershed draining to the Old Plantation Creek. 


\section{APPENDIX 4-A}

Baseline Scenario population forecast model

Baseline Scenario employment forecast model

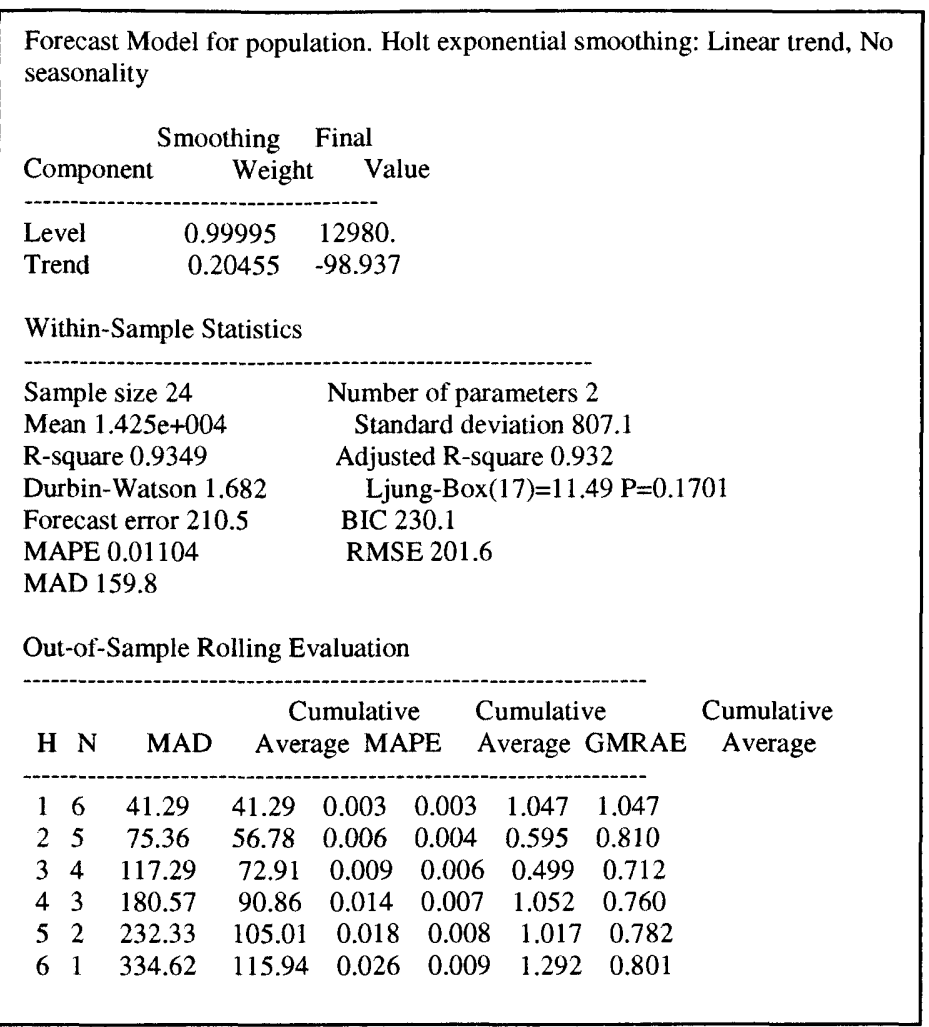

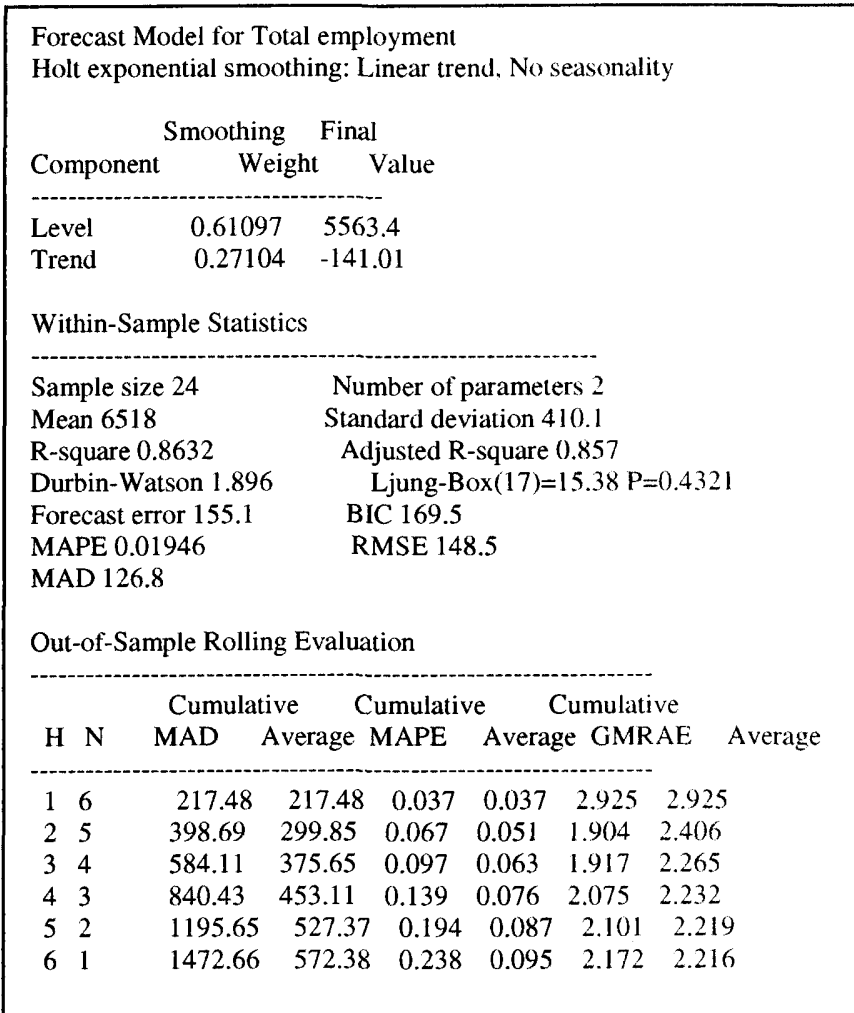

The headings H, N, MAD, MAPE, GMRAE identify the forecast horizon, the sample size, the Mean Absolute Deviation (MAD), the Mean Absolute Percent Error (MAPE), and the Geometric Mean Relative Absolute Error (GMRAE). 
Baseline Scenario per capita personal income forecast model

Baseline Scenario total personal income forecast model

Forecast Model for Percappersincadj

Holt exponential smoothing: Linear trend, No seasonality

Confidence limits proportional to level

\begin{tabular}{lcc}
\multicolumn{2}{c}{ Smoothing } & Final \\
Component & Weight & Value \\
\hdashline Level & 0.90474 & 10591. \\
Trend & 0.03891 & 156.65
\end{tabular}

Within-Sample Statistics

$\begin{array}{lc}\text { Sample size 24 } & \text { Number of parameters 2 } \\ \text { Mean 8451 } & \text { Standard deviation 1666 } \\ \text { R-square 0.917 } & \text { Adjusted R-square 0.9132 } \\ \text { Durbin-Watson 1.991 } & \text { Ljung-Box(17)=15.2 P=0.4191 } \\ \text { Forecast error 491 } & \text { BIC 536.6 } \\ \text { MAPE 0.04106 } & \text { RMSE 470.1 }\end{array}$

MAD 360.3

Out-of-Sample Rolling Evaluation

\begin{tabular}{|c|c|c|c|c|c|c|c|}
\hline \multirow[b]{2}{*}{ H } & \multicolumn{2}{|c|}{ Cumulative } & \multicolumn{2}{|c|}{ Cumulative } & \multicolumn{2}{|c|}{ Cumulative } & \multirow[b]{2}{*}{ Averag } \\
\hline & MAD & Average & & & Average & GMRAE & \\
\hline 6 & 149.66 & 149.66 & 0.013 & 0.013 & 0.480 & 0.480 & \\
\hline 5 & 260.79 & 200.17 & 0.023 & 0.018 & 1.258 & 0.743 & \\
\hline 4 & 228.31 & 207.67 & 0.020 & 0.015 & 0.459 & 0.654 & \\
\hline 3 & 166.91 & 200.88 & 0.015 & 0.018 & 0.248 & 0.556 & \\
\hline 5 & 137.93 & 194.59 & 0.012 & 0.017 & 0.141 & 0.485 & \\
\hline $\begin{array}{ll}6 & 1\end{array}$ & 120.74 & 191.07 & 0.010 & 0.017 & $17 \quad 0.111$ & 0.452 & \\
\hline
\end{tabular}

Forecast Model for Totalincomeudjusted

Holt exponential smoothing: Linear trend, No seasonality

\begin{tabular}{|c|c|c|}
\hline \multirow[b]{2}{*}{ Componen } & \multicolumn{2}{|l|}{ Smoothing } \\
\hline & Weight & Value \\
\hline & & \\
\hline Trend & 0.03421 & 1563.1 \\
\hline
\end{tabular}

Within-Sample Statistics

Sample size $24 \quad$ Number of parameters 2

Mean 1.193e+005 Standard deviation $1.734 \mathrm{e}+(004$

R-square $0.8622 \quad$ Adjusted R-square 0.8559

Durbin-Watson 1.983 Ljung-Box(17) $=19.2 \mathrm{P}=0.6827$

Forecast error $6580 \quad$ BIC 7192

MAPE $0.04222 \quad$ RMSE 6300

MAD 5142

Out-of-Sample Rolling Evaluation

\begin{tabular}{cccccccccc} 
& \multicolumn{6}{c}{ Cumulative } & \multicolumn{2}{c}{ Cumulative } & \multicolumn{2}{c}{ Cumulative } & \\
H & N & \multicolumn{2}{c}{ MAD } & Average MAPE & Average GMRAE & Average \\
\hdashline 1 & 6 & 1737.45 & 1737.45 & 0.012 & 0.012 & 0.553 & 0.553 & \\
2 & 5 & 2894.27 & 2263.27 & 0.020 & 0.016 & 0.970 & 0.714 & \\
3 & 4 & 2519.99 & 2331.73 & 0.018 & 0.016 & 0.525 & 0.657 & \\
4 & 3 & 1827.31 & 2247.66 & 0.013 & 0.016 & 0.262 & 0.564 & \\
5 & 2 & 1424.05 & 2165.30 & 0.010 & 0.015 & 0.143 & 0.492 & \\
6 & 1 & 1162.86 & 2117.56 & 0.008 & 0.015 & 0.105 & 0.457 &
\end{tabular}




\section{LITERATURE CITED}

Associated Press. 2001. Chesapeake Bay states fail to meet cleanup goal, Intelligencer Journal Lancaster, PA. March 13

Associated Press. 2001. Promise to Help Bay to Cost $\$ 518$ Million, Pittsburgh PostGazette. February 18

Baker M. Jr. 2000. Potential Land Use Impacts of a Commuter Toll Reduction on the Chesapeake Bay Bridge-Tunnel. Virginia Department of Transportation, Transportation Planning Division

Baltimore Sun. 2001. Ways to preserve the Bay's watershed High price tag: Cost of protecting land from development is steep, but crucial to Chesapeake's health, The Baltimore Sun. February 24

Barnthouse W. L., G. R. Biddinger, W. E. Cooper, J. A. Fava, J. H. Gillet, M. M. Holland and T. F. Yosie. 1999. Sustainable Environmental Management, SETAC publications, Pensacola, $230 \mathrm{pp}$.

Bay Creek. 2000. About Bay Creek. [also available at: www.bay-creek.com]

Beekman R. L., F. J. Vernberg and W. B. Vernberg. 1997. in F. John Verberg, Winona B. Vernberg, Thomas Siewicki, Sustainable Development in the Southeastern Coastal Zone, University of South Carolina Press

Blankenship K. 2001. Bay Program states preparing tallies of 'preserved' lands, Bay Journal. Vol. 10 - Number 10. January - February

Bowie, G. L., W. B. Mills, D. B., Porcella, C. L. Campbell, J. R. Pagenkopf, G. L. Rupp, K. M. Johnson, P. W. H. Chan, S. A. Gherini, and C. E. Chamberlin. 1985. Rates, constants and kinetics formulations in surface water quality modeling (second edition). EPA/600/3- 85/040, Environmental Research Lab., US EPA, 455 pp.

Buck S. J. 1996. Understanding Environmental Administration and Law, Island Press, Washington, D.C., 225 pp.

Cape Charles Sustainable Technology Park Guidebook. 2000. Brochure

Cape Charles/Northampton County Chamber of Commerce. 1998. Cape Charles a historical treasure. [also available at: http://www.ccncchamber.com]

Chesapeake Bay Commission and The Trust for Public Land. 2001. Keeping Our Commitment: Preserving Land in the Chesapeake Watershed, [also available at: http://www.tpl.org/content_documents/Report.pdf]

Chesapeake Bay Program. 1999. Bay Grasses. [also available at: http://www.chesapeakebay.net/baybio.htm]

Chesapeake Bay Program. 2000. Watershed Profiles [also available at: http://www.chesapeakebay.net/wshed.htm]

Chirps. 2000. Town of Cape Charles newsletter, Spring, [available at: http://www.CapeCharles.org/html/chirps3.html] 
Clark County. 2000. Official Government Website. [also available at:

http://www.co.clarke.va.us/planning.asp]

Commonwealth of Virginia State Water Control Board. 1990. Shellfish growing areas in the Commonwealth of Virginia

Cooper A. 2001. Mattaponi and Others Allowed to Challenge Permit, Richmond TimesDispatch. March 3

Costanza R. 1991. Ecological Economics: The Science and Management of Sustainability. Columbia University Press, New York

Craig County. 2001. History \& General Information [available at: http://www.co.craig.va.us/frm_info.htm]

Dai T., R. L. Wetzel, T. R. L. Christensen, and E. A. Lewis. 2000. BasinSim 1.0 A windows based watershed management package. User's guide.

DeFord S. 2001. State Weighs Land Protections; \$145 Million Program Would Preserve Watershed Areas, The Washington Post. February 1

Dennison W. C., R. J. Orth, K. A. Moore, J. C. Stevenson, V. Carter, S. Kollar, P. W. Bergstrom, R. and A. Batuik. 1993. Assessing water quality with submersed aquatic vegetation. BioScience (43) 2: 86-94

Dickenson County Virginia. 2001. Heritage and History [available at: http://www.dickensonctyva.com/historyinfo.htm]

Eastern Shore of Virginia Economic Development Commission. 2001. Eastern Shore of Virginia [also available at: http://www.easternshore.org/]

EPA region 3 Enviro-Bites. 2001. EPA works with VA developer to minimize runoff impacts in Stafford County, A Wrap-Up of Issues \& Events in EPA's MidAtlantic Region [also available at: http://www.epa.gov/region3/ebytes/ebytes.htm. March 13]

Espey, Huston \& Associates, Inc. 1990. Baseline Environmental and Technical Reference Document for the Proposed Accowmacke Plantation Development, Northampton County, Virginia.

Fiscal and Economic Impacts Highlights. 1996. Accowmacke Plantation. Report

Francis Joseph Schima III. 1993. Groundwater Transport of Escherichia Coli Bacteria to Open Surface Waters on Virginia's Coastal Plain: a GIS Approach. Master's thesis, University of Virginia

Gallagher D. L., A. M. Ditriech, W. G. Reay, M. S. Hayes and G. M. Simmons. 1996. Ground Water Discharge of Agricultural Pesticides and Nutrients to Estuarine Surface Water. Ground Water Monitoring and Remediation

Haith, D. A., and D. E. Merrill. 1987. Evaluation of a daily rainfall erosivity model. Transactions of the American Society of Agricultural Engineers 30(1):90-93.

Harper S. 2001. Activists Look to Clean Nitrogen, Phosphorus from Virginia's Chesapeake Bay, The Virginian-Pilot. March 11

Harper S. 2001. Chesapeake States Fail to Meet Cleanup Goal: Nutrient Reduction Progress has been Made, The Virginian-Pilot and The Ledger-Star. March 12

Harper S. 2001. EPA Seeks Additional Fines for Alleged Violations in Chesapeake, Va., Knight-Ridder Tribune Business News: The Virginian-Pilot. February 15

Hawkins, R. H. 1978. Runoff curve numbers with varying site moisture. Proceedings of the American Society of Civil Engineers. Journal of the Irrigation and Drainage Division 104 (1R4):389-398. 
Horsley Witten Hegemann, Inc. 1992. (Consultants in Water Resources and Land Planning). Ground Water Supply Protection and Management Plan for the Eastern Shore of Virginia. May

Horton T. 2001. On The Bay Critical Area Act in peril Threatened: A series of recent decisions by Maryland's highest court is eroding a 17-year-old law that is key to protecting the state's waterfront from over development. The Baltimore Sun. February 23

Krovetz, D.K., J.H. Porter and D.L. Richardson. 1996. Meteorological measurements of the Virginia Coast Reserve LTER. Data of the Virginia Coast Reserve Long-term Ecological Research Project. 1996 [also available at: http://www.vcrlter.virginia.edu/data/metdata/index.html]

Kuo A. Y., A. J. But, S. C. Kim and J Lin. 1998. Application of tidal prism water quality model to Virginia small coastal basins: Poquoson River, Piankatank River, Cherrystone Inlet, and Hungars Creek. Special Report No. 348 in Applied Marine Science and Ocean Engineering. November.

Kuo A. Y., A. J. But, S. C. Kim and J. Ling. 1998. Application of a Tidal Prism Water Quality Model to Virginia Small Coastal Basins: Poquoson River, Piankatank River, Cherrystone Inlet, and Hungars Creek. Report

Kuo A. Y., S. C. Kim, K. Park, and M. D. Phillips. An expert system aiding permit writers for point source discharges [also available at: http://www.vims.edu/physical/models/tpwqm.htm]

Kuo Y. A., S.C. Kim, K. Park and M. D. Phillips. 1999. Development of an Expert System Based on a Tidal Prism Water Quality Model for Small Coastal Basins in Virginia. (Revised March 2000 for TPWQM-VPDES Version 1.1). Report

Kuo, A. Y., S. C. Kim, K. Park and M. D. Phillips. 1999. Development of an Expert System Based on a tidal Prism Water Quality model For Small Coastal Basins in Virginia. Report

Latane III L: 2001. Growth Linked to Bay Pollution Rise: Grappling with Growth. Richmond Times-Dispatch. February 5

Lazaroff C. 2001. Chesapeake Bay Protection Carries \$1.8 Billion Price. Environment News Service, World Reporter (TM) -Valentine Holdings Limited. February 12

Luckenbach M. 2001. personal communication

Luckenbach M. W., M. H. Roberts, Jr. and K. Boyd. 1996. Preliminary evaluation of water quality in tidal creeks of Virginia's Eastern Shore in relation to vegetable cultivation. Virginia Institute of Marine Science, Scientific Report \#133

Luckenbach M. W., M. H. Roberts, Jr., and K. Boyd. 1996. Preliminary evaluation of water quality in tidal creeks of Virginia's Eastern Shore in relation to vegetable cultivation, Virginia Institute of Marine Science Scientific Report \#133 October.

Malcolm Pirnie, Inc. 1997. Ground Water Withdrawal Impact Analysis, Town of Cape Charles, Cape Charles, Virginia. June

Malinovsky S. 1986. Small scale farming of the hard clam on Long island, New York. The Clam Farm, Inc.

Mandel, R. 1993. The impact of septic systems on surface water quality. M.S. thesis. School of Civil \& Environmental Engineering, Cornell University, Ithaca, NY. Marshall D. W. Geographic Information System for Sustainable Development: South Carolina's Edisto River Basin Project. in F. John Verberg, Winona B. Vernberg, 
Thomas Siewicki, Sustainable Development in the Southeastern Coastal Zone, University of South Carolina Press

May D. T. 2001. Land preservation cost studied State must find funds to save Chesapeake Bay watershed, The Harrisburg Patriot. February 15

McCord J. 2001. Report says watershed preservation needs boost, The Baltimore Sun, February 13

McMahon T. E. 2001. Before the Bay Is Beyond Repair. The Washington Post. March 4

Michèle H. and S. Makridakis, M3 - COMPETITION June 27-30, INSEAD. $19^{\text {th }}$ International Symposium on Forecasting. France.

Mills S. H. 1996. Eastern Shore Almanac. A Guide to Environmentally Sensitive Living on Virginia's Eastern Shore.

Moore K. A. and R. L. Wetzel. 2000. Seasonal variation in eelgrass (Zostera marina L.) responses to nutrient enrichment and reduced light availability in experimental ecosystems. Journal of Experimental Marine Biology and Ecology. 244: 1-28

Moore K. A., H. A. Neckles and R. J. Orth. 1996. Zostera marina (eelgrass) growth and survival along a gradient of nutrients and turbidity in the lower Chesapeake Bay. Marine Ecology Progress Series 142: 247-259

Moore K. A., R. L. Wetzel and R. J. Orth. 1997. Seasonal pulses of turbidity and their relation to eelgrass (Zostera marina L.) survival in estuary. Journal of Experimental Marine Biology and Ecology 215: 115-134

Natural Resources Conservation Service. 2000. Soil Survey Geographic (SSURGO) Data Base [also available at: http://www.ftw.nrcs.usda.gov/ssur_data.html]

Newton S. H. 1995. A Guide to Aquaculture Development and Industry Information. Virginia Department of Agriculture and Consumer Services. Virginia Aquaculture Plan.

Northampton County Board of Supervisors, June 28. 1994. Sustainable Development Task Force, The Sustainable Development Action Strategy for Northampton County, Virginia. Northampton County strategy document

Odum, E. P. 1971. Fundamentals of Ecology (third edition). W.B. Saunders Co., Philadelphia, PA, 574pp.

Orth R. J. and K. A. Moore. 1984. Distribution and abundance of submerged aquatic vegetation in Chesapeake Bay: a historical perspective. Estuaries. 7, 4B: $531-540$

Porter E. D. et al. Geographic Information Processing Assessment of the Impacts of Urbanization on Localized Coastal Estuaries: a Multidisciplinary Approach

Professional Builder. 2001. Maryland Looking Smart, Professional Builder, Volume 66, Issue 2 (ISSN: 1072-0561). February 1

Reay W. G., D. G. Gallagher and G. M. Simmons. 1992. "Groundwater discharge and its impacts on surface quality in a Chesapeake Bay Inlet." Water Resource Bulletin 28 (6): 1121-1134

Richardson, D. L. 1992. Hydrogeology and analysis of the ground-water-flow system of the Eastern Shore, Virginia. U. S. Geological Survey Report 91-490

Robinson M. A. and W. G. Reay. 1999. Ground water flow and nitrogen quality within an outer mid-Atlantic coastal plain watershed. Report

Robinson M., D. Gallagher and W. Reay. 1998. Field observations of tidal and seasonal variation in ground water discharge to tidal estuarine surface water. Ground Water Monitoring and Remediation. Journal. Winter 
Roth R. 2001. River Coalition Offers an Independent Assessment of Water Quality: Most Remaining Problems are Politically Difficult to Address. Roanoke Times and World News. March 14

Roy Pearson. 2000. personal communication

Ryan Hodges, of Clarkson \& Wallace, Inc. 2001. About Bath County [also available at: http://www.marketplace.staunton.va.us/valyre/bathinf.html]

Shabman L. 1997. Land Settlement, Public Policy, and the Environmental Future of the Southeast Coast. F. John Vernberg, Winona B. Vernberg, Thomas Siewicki (eds.), Sustainable Development in the Southeastern Coastal Zone, University of South Carolina Press, 1997

Simmons, G. M. and W. G. Reay. 1990. The relationship between land use and submarine ground water discharge. P.p. 29-32, in New Perspectives in the Chesapeake System: A Research and Management Partnership. Proceedings of A Conference. Baltimore, Maryland, December 4-6,

Soil Conservation Service. 1986. Urban hydrology for small watersheds. Technical Release No. 55 (2nd edition). U.S. Department of Agriculture, Washington, DC.

Springston R. 2001. State Streams Cleanup Will Be Costly: Plans Alone Put at $\$ 59$ million, Virginia Department of Environmental Quality, Richmond TimesDispatch. February 8

The San Isabel Foundation. 2001. Nonprofit Land Trust, Protection options, at [also available at: http://www.sanisabel.org/index.html]

The TAF Group. 1999. Water Quality Impact Assessment for Bay Creek Palmer Golf Course. December.

The Virginian-Pilot. 2001. Polluting Sprawl is Virginia's Problem, The Virginian-Pilot and The Ledger-Star. March 14.

Turner K. R., D. Pearce and I. Bateman. 1993. Environmental Economics, An elementary introduction. The John Hopkins University Press, Baltimore. 328 pp.

U. S. Environmental Protection Agency. 1980. Design manual: Onsite wastewater treatment and disposal systems. EPA-62511-80-012. U.S. Environmental Protection Agency, Washington DC.

United Nations. 1994. Agenda 21: Program of Action for Sustainable Development. Rio Declaration on Environment and Development. United Nation Publications, New York, $294 \mathrm{pp}$.

Vernberg F. J., B. W. Vernberg, T. Siewicki. 1997. Sustainable Development in the Southeastern Coastal Zone, University of South Carolina Press. The Belle W. Baruch Library in Marine Science Number 20.

Vig N. J. and M. E. Kraft. 1999. Environmental Policy, CQ Press, Washington D.C., 416 pp.

Virginia Secretary of Natural Resources, Virginia Chesapeake Bay Local Assistance Department, Virginia Department of Conservation and Recreation, Virginia Department of Environmental Quality. 1999. Eastern Shore Coastal Basins Tributary Nutrient Reduction Strategy. November

Virginian-Pilot. 2001. If Everglades can be Saved why not Chesapeake Bay? The Virginian-Pilot and The Ledger-Star. February 26, 
Wilbur Smith Associates. 1999. Shore Engineering, Fitzgerald and Halliday, Inc., US Route 13 Corridor Plan Eastern Shore of Virginia. Accowmack-Northampton Planning District Commission. July

Wischmeier, W. H., Smith, D. D. 1978. Predicting rainfall erosion losses - a guide to conservation planning. Agricultural Handbook 537, U.S. Department of Agriculture, Washington DC.

Yates, M. V. and S. R. Yates. 1989. Septic tank setback distances: a way to minimize virus contamination of drinking water. Ground Water (27) 2: 202-207. 
VITA

\section{SARUNAS ZABLECKIS}

Born in Vilnius, Lithuania, August 7, 1977. Graduated from Ozo Senior High School (Vilnius, Lithuania) in 1995. Earned BA in Ecological Biology from Vilnius University (Lithuania) in 1999. The same year was awarded Edmund S.

Muskie/Freedom Support Act Graduate Fellowship. Entered MS program in College of William and Mary, Virginia Institute of Marine Science/School of Marine Science in 1999. 